I

Türkiye'de 1980 Sonrası Sosyal

Politikaların Aile Üzerindeki Etkisi

Betul Çiçek



1980 Sonrasi Küresellesmenin Etkisi ile Güçlenen Neoliberal Politikalarin Sosyal Devletin Rolüne Etkisi ve Küresel Sivil Toplumun Ortaya Çıkıșı

Merve Ege Yanbasar Aktaş $y$

Mekân ve Yaşı।lık

Beyza isen

$\searrow$

Birlesmis Milletler Koruma

Sorumluluğu Doktrininin

(Responsibility to Protect) insani

Müdahalelere Olan Katkısı ve 2011

Libya Müdahalesi

Sümeyye Semiha Büyük $y$

Türkiye'de Tutunma Stratejisi Olarak Evlilik: Mülteci Evliliği

Kamer Çamurluoğlu

У

Elektronik Insan Kaynakları Uygulamalarının Algılanan Net Faydaya Etkisi ve Kullanım Kolaylığının Araci Rolü: Türkiye Banka Sektöründe Bir Araștırma

Prof. Dr. Yonca Deniz Gürol Furkan Bağrıyanık

\title{
toplunsal değișim
}

2022 | CILT | VOLUME 4 SAYI | NUMBER 1

ISSN 2651 - 4850

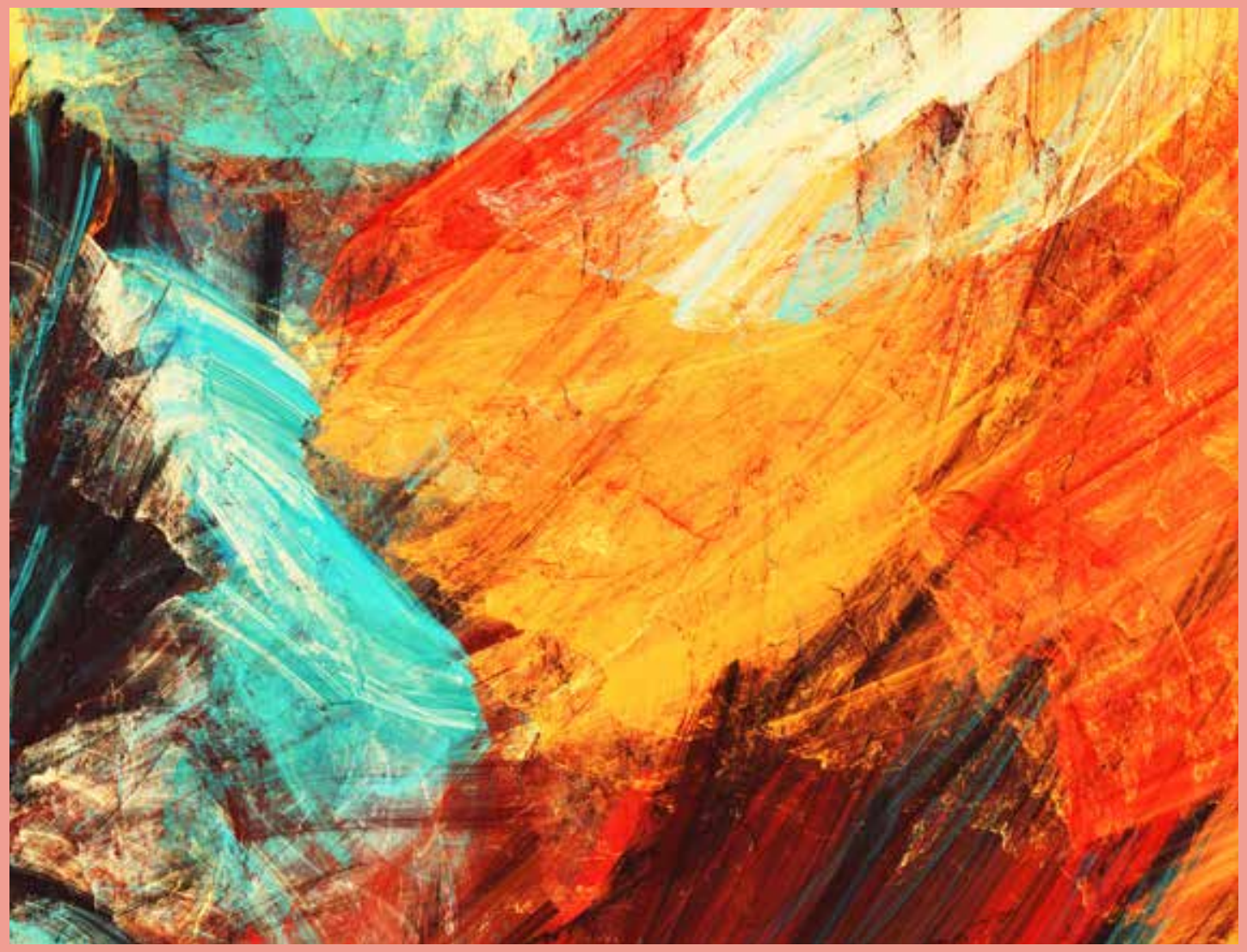


toplumsal değigisim
Cilt/Volume: 4 Sayıı 1 Number: 12022

ISSN: 2651-4850 E-ISSN: 2717-9141

DOI: https://dx.doi.org/10.51448

Loplumsal değ́sisim uluslararası ve hakemli bir dergidir. Yayımlanan makalelerin sorumluluğu yazarına/yazarlarına aittí. oplumsal degrisim is the official peer-reviewed, international journal of the Insan ve Medeniyet Hareketi. Authors bear responsibiliti for the content of their published article.

Insan ve Medeniyet Hareketi Adına İmtiyaz Sahibi/Owner Kemal Özden

Yazı İșleri Müdürü/Cheif Executive Office

Mehmet Bulayır

Genel Yayın Yönetmeni Executive Edìtor

Haluk Nas

Editör/Editor

Mustafa Özel (Editor-in-Chief, Prof. of School of Islamic Studies) Fatih Sultan Mehmet Vakıf Üniversitesi

Yayın Kurulu/Editorial Advisory Board

Ahmet Koyuncu, Necmettin Erbakan Üniversitesi, Konya, Türkiye Ferhat Tekin, Necmettin Erbakan Üniversitesi, Konya, Türkiye Hızrr Murat Köse, İstanbul Medeniyet Üniversitesi, İstanbul, Türkiye Hüseyin Aydoğdu, Erzurum Teknik Üniversitesi, Erzurum, Türkiye Hüseyin Korkut, Millî Eğitim Bakanlığı, Talim ve Terbiye Kurulu, Ankara, Türkiy Meemet Ali kin, Istanbul Medeniyet Universitesi, Istanbul, Türkiye Mehmet Fati Aysan, Marmara Universitesi, İstanbul, Türkiye Muhammet Kizlgecit, Atatürk Üniversitesi, Erzurum, Türkiye

Muhammet Öztabak, Fatih Sultan Mehmet Vakıf Üniversitesi, İstanbul, Türkiye Murat Şentürk, İstanbul Üniversitesi, İstanbul, Türkiye Osman Aydint, Marmara Universitesi, , stanbul, Türkiye Zübeyir Nişanc, Marmara Üniversitesi, İstanbul, Türkiye 


\section{İçindekiler / Table of Contents}

Akademik Ị̇erik Danışmanlığ//Content Advisor

\section{fibula}

Salacak Mahallesi, Neyzenbaşı Halil Can Sokak, No:21 Üsküdar / İstanbul

Elektronik Posta: info@fibulayayincilik.com

Yayın Koordinatörü/Publishing Coordinator

Reyyan Beyza Altan

Yayina Hazırlık/Preparation for Publication

Fatih Çavuşoğlu

Tasarım ve Uygulama/Design and Application

Sevde Bozat

Yayın Türü/Type of Publication

Türkçe İngilizce Süreli Yayın / Turkish English Periodical Publication

Yayın Periyodu/Publishing Period

Altı ayda bir Ocak ve Temmuz aylarında yayımlanır / Biannual (January \& July)

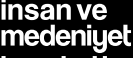

harekeht

İletişim/Correspondence

İnsan ve Medeniyet Hareket

Bahariye Mevlevihanesi, Eyüp Merkez Mahallesi, Silahtarağa Cad. No: 12 Eyüp, İstanbul

Telefon: +90 (212) 501-3171 Web: http://toplumsaldegisim.com

Elektronik posta: admin@toplumsaldegisim.com
MAKALELER/ARTICLES

Türkiye'de 1980 Sonrası Sosyal Politikaların Aile Üzerindeki Etkis

The Effects of Post-1980 Social Policies on the Family in Turkey

Betul Çİ̧EK

Mekân ve Yaşll1k

Space and Elderliness .28

Beyza İSEN

Türkiyede Tutunma Stratejisi Olarak Evlilik: Mülteci Evliliği

Marriage as an Adaptation Strategy in Türkiye: Refugee Marriage

Kamer ÇAMURLUOĞLU

1980 Sonrasi Küreselleşmenin Etkisi ile Güçlenen Neoliberal Politikalarin Sosyal Devletin Rolüne Etkisi ve Küresel Sivil Toplumun Ortaya Çıkışı

The Effect of Neoliberal Policies Strengthened by Globalization After 1980, on the Role of the Social State and the Emergence of Global Civil Society …………………………………….... Merve Ege YANBASAR AKTAS

Birleşmiş Milletler Koruma Sorumluluğu Doktrininin (Responsibility to Protect) İnsani Müdahalelere Olan Katkısı ve 2011 Libya Müdahalesi

The UN Responsibility to Protect Doctrine's Contribution to Humanitarian Interventions and 2011 Libya Intervention Sümeyye Semiha BÜYÜK

Elektronik İnsan Kaynakları Uygulamalarının Algilanan Net Faydaya Etkisi ve Kullanım Kolayliğinin Aracı Rolü: Türkiye Banka Sektöründe Bir Araştırma

The Effect Of Net Perceived Benefit Of Electronic Human Resource Applications and The

Intermediate Role Of Practicality

Prof. Dr. Yonca Deniz GÜRO

Furkan BAĞRIYANIK 


\section{Türkiye'de 1980 Sonrası Sosyal Politikaların}

Aile Üzerindeki Etkisi

Betul ÇIÇEK'
The Effects of Post-1980 Social Policies

on the Family in Turkey

Betul ÇIÇEK ${ }^{1}$

\section{Özet}

Sosyal politika uygulamalarının ilk örnekleri Fransız İhtilali’nin ve Sanayi Devrimi’nin beraberinde getirdiği köklü değişimlere dayanır. Dönemin konjonktürü bize özellikle kadın ve çocuk işçilerin katlanılmaz şartlarda çalıştırıldığı ve yaşamlarına bu tehlikeli koşullarda devam ettiği bir çerçeve sunar. Dolayısıyla Sanayi Devrimi ve Fransız İhtilali sonrası sosyal politikaların ilk konusunu isçilerin korunması ve yaşam şartlarının iyileştirilmesi oluşturmaktaydı. Ancak zamanla devletlerin sosyal politikaları toplumsal iyileştirmelerde kullanması ve toplumsal anlamda sosyal sorunların artmasıyla bu kapsam çesitlenip artmıștır. Toplumun temel dinamiklerinden olan aile kurumu, devletlerin nüfus odaklı stratejiler geliştirmeye başlamasıyla beraber sosyal politikaların da odak noktalarından biri haline gelmiştir. Bu nedenle aile kurumunun değissiminde sosyal politikalardan kaynaklı bir etki söz konusudur. Türkiye'de Cumhuriyet dönemine geçişle birlikte, ilerlemenin yönü Avrupa kabul edildiği için, yasa, düzenleme ve uygulanan politikalar hissedilir bir şekilde Avrupa kökenli olmuştur. Bu strateji ile birlikte Batının belli bir süreçle edindiği kazanım ve yasaların, bu yasaların yabancısı olan Türk toplumuna aktarılması, ülkemizde aile kurumu açısından olumsuz durumlarla sonuçlanmıștır. Bu çalıșmada Türkiye'de özellikle 1980 sonrası uygulanan Sosyal Politikaların, Batılılaşma ve modernleşme süreçleriyle birlikte, aile kurumu üzerinde, doğrudan veya dolaylı bir şekilde oluşturduğu değișim ve dönüsümler saptanmaya çalıșılmıștır. Aile düzeyinde görülen bu değişimleri daha iyi anlamak için çalışmaya dayanak sağlayacak bazı istatistikî verilerden yararlanılmıștır.

\section{Anahtar Kelimeler}

Aile • Cocuk • Fransız İhtilali • Kadın • Sanayi Devrimi • Sosyal Politika • Yaşlılık

1 YÖK 100/2000 Doktorant1, Afyon Kocatepe Üniversitesi, Sosyal Bilimler Enstitüsü, Sosyoloji Bölümı Doktora Öğrencisi, betulcicek1994@gmail.com, ORCID: 0000-0001-8067-1119

\section{Abstract}

The first examples of social policy practices are based on the radical changes brought about by the French Revolution and the Industrial Revolution. The conditions of the period present us a framework in which women and child workers are employed in intolerable conditions and continue their lives in these dangerous circumstances. Therefore, the first issue of social policies after the Industrial Revolution and the French Revolution was the protection of workers and the improvement of their living conditions. However, over time, this scope has diversified and increased with the use of social policies in social improvements and the increase in social problems. The family institution, which is one of the basic dynamics of the society, has become one of the focal points of social policies as the states started to develop population-oriented strategies. For this reason, there is an effect of social policies in the change of family institution. With the transition to the Republican period in Turkey, since the direction of progress was accepted as Europe, the laws, regulations and policies implemented were of European origin. With this strategy, the transfer of the gains and laws that the West has gained through a certain process to the Turkish society, which is a foreigner of these laws, resulted in negative situations in terms of the family institution in our country. In this study, it will be tried to determine the direct or indirect changes and transformations of the Social Policies implemented in Turkey, especially after 1980, together with the Westernization and modernization processes, on the family institution. In order to better understand these changes seen at the family level, some statistical data will provide a basis for the study.

\section{Keywords}

Children • Family • French Revolution • Industrial Revolution • Social Policy

$$
\text { - Older People • Women }
$$

1 YÖK 100/2000 Doctorate, Afyon Kocatepe University, Social Sciences Institute, Department of Sociology, PhD Student, betulcicek1994@gmail.com, ORCID: 0000-0001-8067-1119 
Aile kurumu, öneminden dolayı siyasi yapılanmaların öncelikli ilgi alanlarından olmuştur. Bu nedenle devletlerin aile kurumu ile olan iliskisine baktığ mızda, aile ile ilgili kuralları belirleyen, kontrol eden ve düzenleyen bir yapıda olduğunu ifade edebiliriz (Altunsu Sönmez, 2013: 307). Bununla birlikte aile kurumunun toplumun temel dinamiklerinden olması nedeniyle, toplumun büyük ölçekli değişimlerinde diğer kurumlara nazaran daha derin bir etkiye sahiptir. Sosyal politikaların bir alt dal olan aile politikaları da toplum üzerinde geniş çaplı bir etkiye sahiptir. Sosyal politikaların bu denli etkili olması ve devlet stratejileri için büyük önem taşıması, sosyal politikaların varlığının günümüze kadar devam etmesini sağlamıştır.

Sosyal Politikanın Tanım ve Kapsamı

Sosyal politika, en genel anlamıla devletin bir ülkedeki tüm bireyler için -özellikle bakıma ve korunmaya ihtiyacı olanla için- koruyucu, güçlendirici, sosyal adalet ve eşitliği sağlayıcı eğitim, sağlık, konut, sosyal güvenlik, sosyal yardım ve bireysel sosya hizmetleri içeren plan, proje ve hizmetlerin bütünü olarak ifade edilebilir (Pierson ve Thomas, 1999'dan akt. İçağasıŏlu Çoban ve Özbesler, 2009: 33). Bu anlamda toplumun tüm kesim ve sosyal sorunlarını kapsayan sosyal nitelikli tüm yaptırımları konu ala sosyal politikanın kişi ve konu bakımında olmak üzere temelde iki tür kapsamı bulunmaktadır (Altan, 2007: 3)

Sosyal politikaların kişi bakımından kapsamı, sosyal sorunların farklılașmasına bağ olarak dinamik bir profil çizmiştir. Nitekim başlarda sosyal politikanın kişi bakımından kapsadığı ilk ve tek kesim işçi sınıfı olmuş olmasına rağmen günümüzde bu kapsam sos- yal sorunların çeşitliliğiyle paralel bir şekilde oldukça genişlemiștir (Köse, 2018: 16). Sosyal politikanın konu bakımından kapsamına bakacak olursak, başlarda tek konusu işçi haklarının korunması olan sosyal politikalar, günümüzde sağlık, eğitim, güvenlik, beslenme, korunma, barınma ve istihdam gibi birçok konuyu kapsamış durumdadır (Bedir ve Bülbül, 2018: 3-5).

\section{Sosyal Politikanın Ortaya Çıkıșı}

Sosyal politikanın ortaya çıkışını hazırlayan koşullar temelde iki tarihi olaya dayanır. Bunlar Fransız İhtilali ile Sanayi Devrimi'dir. Fransız İhtilali; Sanayi Devrimi ve sonrasında gerçekleșen toplumsal ve ekonomik dönüşümlerin gelişmesini sağlayan düşünsel arka planı oluşturmuş ve Sanayi Devrimi'nin doğuşunu hızlandırmıştır (Bedir ve Bülbül, 2018: 5). Böylece Sanayi Devrimi ile birlikte toplumda ve ekonomide büyük çaplı değişimler yaşanmış, toplum sanayilessme ve fabrika merkezli bir şekilde kent odaklı olarak yeniden yapılanmıştır. Oysa Sanayi Devrimi'nden önce çalışmanın büyük bir bölümü, kırsal alanda ve üretim merkezi olan evlerde gerçeklesirdi. Ancak sanayilesmeyle birlikte is ile ev birbirinden ayrılmıs, fabrikalar üretimin odak noktası haline gelmiştir. Böylece tarım toplumlarında aile, eğitim, siyaset, çalışma gibi birçok toplumsal kurumda önemli değişimler yaşanmıştır (Bozkır Serdar, 2018: 12-13). Bu yeni toplumsal şartlarda en kötü durumda olanlar, ucuz emek gücünü temsil eden işçi çocuk ve kadınlardı. Bu nedenle, sosyal politika ilk etapta özellikle korunmaya muhtaç isçi çocuk ve kadınlar üzerinde yoğunlaşmıştır (Talas, 1992: 15-16). Bununla birlikte sanayileşme süreci ile beraber bu dönemin hakim sınıfı sermaye sahipleri ve işverenler olmuştur.
Fabrika sistemine geçişle birlikte kitle üretimi bu kesimin gücünü ve sermayesini arttırmıştır. Mevcut sistemin devam edebilmesi için emeğinden başka hiçbi şeyi olmayan iş̧̧i sınıfina ihtiyaç duyulmaktaydı. Bu nedenle Sanayi Devrimi ile birlikte bu sınıf belirgin bir şekilde toplumda yer edinmiştir.

Bu yeni sınıfın daha sonraki süreçt hak araması ve örgütlenme mücadelesi, sanayi toplumunun sosyal boyutunu et kileyecek ve sosyal politika oluşumunda etkili olacaktır. Ancak zamanla bir araya gelerek işçi sendikaları kuran ve işverenler karşısında hak arayışına giren işçler, sendikalaşmanın ilk dönemlerinde işverenlerin kendi çıkarları için polis mafya ve siyasetçilerle yaptıkları işbirliği ve açlık sınırında bulunan on binlerce insanın karın tokluğuna çalıșmaya hazı olması gibi nedenlerden dolayı başarıl olamamışlardır. Bu durumda araya gir mek zorunda kalan devlet, çeșitli politikalar uygulamak durumunda kalmıştır. Dolayısıyla soysal politika ilk olarak işverenler karşısında zayıf olan işçi sınıfının ekonomik ve sosyal hak mücadelesi et rafinda sekillenmistir. Daha sonra gene anlamda toplumda hakim güç otoriteleri karşısında zayıf ve korunmasız olan kesimlerin ekonomik ve sosyal alanda korunmasını sağlayacak hakların kazanılması çerçevesinde genişlemiștir. Ancak bilinmesi gerekir ki sosyal politikanın gelişiminde çalışma hayatındaki bu değişimlerin yanında dönemin beraberinde getirdiği kentleşme ve demografik değişimlerin de etkisi olmuştur (Bozkı Serdar, 2018: 15-18).

Sosyal politika henüz bir bilim dalı olarak ortaya çıkmadan ve kurumsallaşmadan önce de sosyal politikalara benzer uygula- maların varlığı söz konusuysa da ancak modern çağda toplumlar bir arada yaşayabilmek için detaylı ve kapsamlı gereklilikler ortaya koymuş ve devletin insan ilişkilerine doğrudan müdahale edici bir nitelik kazanmasına neden olmuştur. Dolayısıyla denilebilir ki sınıflı toplum yapısının sanayileşmeyle birlikte, belirgin bir şekilde toplumda yer alması, sosyal sorunların hızla artmasına ve 19. yüzyılın ikinci yarısında yaşanan gelişmelerin de etkisiyle sosyal politikanın bir bilim dalı olarak ortaya çıkmasına neden olmuştur (Aslan, 2018: 265).

Sosyal politikaların devlet eliyle gerçekleşmesi, devletin toplumsal sorunlara çözüm getirme anlamında bir "sosyal devlet" olma yolundaki sürecin de önünü açmıştır. Böylece Sanayi Devrimi sonrasında aile bireyleri üzerinde ilk defa aile dışından olan aktörler etkili olmaya başlamıştır. Burada kullanılan sosyal devlet ibaresi dikkat çekicidir. Çünkü sosyal devletin temel özelliği, belirlenen hedeflere erişmek açısından, müdahale edici bir niteliğe sahip olmasıdır. Böylece sosyal devletin bu yapısı ile sonraki süreçte aile kurumunun diş etmenlere açık hale gelmesi için gereken zemin hazırlanmış olmaktadır. Türkiye'de ise "devletin aktör olarak sosyal politikalarda açıkça/hukuki varlığı ilk defa 1961 Anayasası'ndaki 'sosyal hukuk devleti' ilkesi ile net bir şekilde görülmeye başlamıştır." (Taşç1, 2017: 7-9)

Özetle ifade etmek gerekirse sosyal politikalar 19. yüzyılda Batı Avrupa'da Sanayi Devrimiyle beraber ortaya çıkan büyük bir ekonomik dönüşümün sonucunda derin bir sefalete düşen işçilerin yaşadığı sorunları 
çözmek amacıyla ortaya çıkmıştır (Işıkhan, 2014: 7). Ancak günümüzde toplumun neredeyse tüm kesimlerini kapsayan, sosyal sorunları çözmeyi ve hayat koşullarını iyi leştirmeyi amaçlayan bir vatandaşlık hakkına evirilmiştir. Dolayısıyla dinamik bir yap olan sosyal politikalar günümüzde öncede ilgilendiği konuların yanında, “... dışlanma, ayrımcılık, çevre sorunları, tüketici haklar1, dezavantajlı gruplar olarak nitelendirilen kadınlar, gençler, çocuklar, yaşlılar, eski hükümlüler, göçmenler, engelliler ve diğe gruplara yönelik üçüncü kuşak olarak adlandırılan sosyal politikalar" gibi birçok konuyla ilgilenmektedir (Bozkır Serdar, 2018: 5-6).

\section{Türkiye'de Sosyal Politika}

Türkiye'de sosyal politikanın tarihse gelişimi başlıca iki ana döneme ayrılarak incelenebilir. Bunlar Cumhuriyet öncesi ve Cumhuriyet dönemidir. 1908 yılından önce ülkede bireysel iş ilişkileri ile ilgili birkaç nizamnamede ve Mecelle'de bireysel iş ilişkileri ile ilgili sınırlı sayıda düzenlemeye yer verilmişse de Cumhuriyet öncesi dönemde ülkedeki siyasi, ekonomik ve sosyokültürel koşullar sosyal politikanın oluşmasına imkân tanımamıştır (Bozkır Serdar, 2018: 63 65). Çünkü Osmanlı Devleti'nde toplumsal ilişkilerin şekillenmesinde etkili olan üretim şekli ağırlıklı olarak tarıma dayalıydı (Özaydın, 2018: 43). Bununla birlikte Osmanlı dönemindeki sosyal güvenlik anlayışı çocuk ve aile üzerinden şekillenmiştir. Nitekim imparatorlukta ilk ve temel sosyal güvenlik kurumunu 'ocak' olarak da bilinen geniş aile yapısı oluşturmaktaydı. Aile, her birey için özellikle de kadınlar ve bakıma ihtiyaç du- yanlar için sürekli ve temel bir koruma mekanizmasıydı. Bunun yanında komşuluk ve akrabalığa bağlı yardımlaşma da Osmanlı'da her dönem etkin bir sosyal güvenlik aracı olmuştur. Bu yardımlaşma kalkanının yanında birçok konuda karşılıksız yardım ve hizmetlerde bulunan vakıf kurumları da sosyal güvenlik niteliği taşımaktaydı. Daruş-Şifalar ve Loncalar bunun en iyi örnekleridir (Alper, 2018: 232-233). Bu nedenlerden dolay1, sosyal politika süreci Batıda gerçekleştiği gibi Osmanlı Devleti'nde gelişmemiştir.

Diğer taraftan Sanayi Devrimi ve Fransız İhtilali gibi büyük olayların yaşandığı dönemde meydana gelen değişimlerden yalnızca Batı değil Batı dışındaki toplumlar da etkilenmiştir. Osmanlı Devleti'nin son dönemlerinde tartışılan geri kalmışlık konusu bu büyük çaplı değişimlerin bir sonucudur. Özellikle Fransız İhtilali'nin neden olduğu milliyetçilik akımı ve Osmanlı Devleti'nin son dönemlerinde yaşanan kaos ortamı ve toplumsal sorunlar ile Osmanlı'nın, Batının teknolojik ilerlemesine kapalı bir tutum sergilemesi bu tartışmaları alevlendirmiştir. Gelinen noktada toplumdaki geri kalmışlık hissi bir çıkış yolu aramaya itmiş ve bu eğilim devrin misyonunu da şekillendirmiştir. Böylece ülke için ilerleme yönü Avrupa, ilerleme yolu ise Avrupa'nın kurum ve kuruluşlarının ülkeye alınması șeklinde kabul edilmiştir (Aytaç, 2012: 127). Böylece "Tanzimat'a kadar hukuk düzenini Türk örfi hukuku ve İslam hukuku anlayışı içinde sürdüren Türk toplumu, Tanzimat Fermanı'ndan (1839) itibaren tüm kurumlarında köklü değişimler yapmaya yönelmiştir. Bu tercih, tüm kurumlarda olduğu gibi hukuk sisteminin çağın şartlarına göre düzenlenmesinde de Batı'nın sanayileşmiş ve kalkınmış modellerinin Türk toplum yapısına uyarlanması şeklinde ele alınmıştır." (Özaydın, 2018: 47)

Osmanlı'da 19. yüzyılın sonuna doğru Batı model alınarak yapılan değişimler sonucunda yaşanan köklü değişimler ve çözülmeye başlayan ekonomik toplumsal yapı, vakıf ve loncalar gibi toplumsal değerler açısından büyük önem taşıyan, dayanışma ve yardımlaşma kurumlarının da etkinliğini azaltmıştır. Bu durumun en büyük nedeni Türk modernleşmesinin temel dinamiğinin yasal düzenleme ve hukuksal yaklaşımların Batı kaynaklı olmasıdır. Nitekim toplumsal yaşamda gerçekleşen değişim ve dönüşümlerin büyük bir kısmı hukuksal reformlar ya da farklı ülkelerin hukuklarının kabulü ile gerçekleşmiştir (Aytaç, 2012: 130). Bu yönelim, Cumhuriyetin ilanından sonra da devam etmiş ve Türkiye'de ailenin siyasal bir sorun olarak ele alınmasına yol açmıştır. Dolayısıyla "çocuklar, eğitim, aile içi ilişkiler, ebeveynlik gibi kimi sorunlar güncel bir tartışma konusu haline gelmişti. $\mathrm{Bu}$ nedenle, siyasetin kurgulanmasına ilişkin bir zihniyet değişikliği de gündeme gelmişti’ (Aytaç, 2012: 128). Çünkü Cumhuriyetin ilan yalnızca siyasi bir yapı değişikliğinin ötesinde "ekonomik, sosyal ve hukuki bakımdan bi dönüşümü içermektedir. Cumhuriyetin ilan ve sonrasında kabul edilen 1924 Anayasas ile bireysel özgürlükler ve doğal hukuk anlayışı çerçevesinde önemli adımlar atılmaya başlanmıştır" (Özaydın, 2018: 49). Cumhuriyet döneminde ülkemizdeki politikalara bağlı olarak gerçekleşen değişimlerin kökeninde uygulanan politikalarla aile yapımızın uyuşmamasından kaynaklı problemlerin bulunduğunu da vurgulamak gerekir. Çünkü ilk uygulanan politikalarla birlikte çeşitli değişimler de meydana gelmişti. Bu değişimler kendi toplumumuza göre sorun addedilecek nitelikte değişimlerdi. Uygulanan politikalar öncelikle çocuk tartışmalarının oluşmasına neden olmuştu. Bu doğrultuda çocukluk mefhumu yeniden yapılanmıştır. Çocukluğun ve gelecek nesillerin yeniden yapılandırılması, çocuk ve ebeveynler arasındaki ilişkinin de yeniden yapılandırılmasını gerektirmiştir (Aytaç, 2012: 129). Bu nedenle ülkemizde sosyal politikalar konusunda toplumun yabanc1sı olduğu Batı kökenli değişimler gereksinim olarak görülmüş ve uygulamaya koyulmuştur. Türkiye'de sosyal politika girişimlerine 1920 'lerin başlarında ilk adımlar atılmış ve Cumhuriyet ile birlikte bu süreç çeşitli durumlara göre değişimler geçirerek devam etmiştir (Talas, 1992: 33).

\section{0 Öncesi Sosyal Politikalar}

1980 öncesi sosyal politikalar Cumhuriyetin ilan edildiği ilk y1llarda sosyal politika girişimleri, tek partili bir dönem olmanın da etkisiyle sınırlı bir şekilde gelişim göstermiştir. 1923'te sanayileşme sürecinin de etkisiyle izlenen liberal politikaların başarısız kalması üzerine 1932 yılından sonra devletçi politikalar uygulanmaya başlanmıştır. Bununla birlikte bu dönemde ilk defa çalışma hayatına geniş kapsamlı bir müdahale söz konusudur. 1945 'ten sonra çok partili sisteme geçmiş olmanın ve iç ve dış faktörlerin de etkisiyle siyasi ve ekonomik yapıda ortaya çıkan gelişmeler sonucunda devlet tarafından 
işçileri koruyucu kurumsal ve hukuki düzenlemeler yapılmış, asgari ücret uygulamasına başlanmıştır. Kurumsal alanda ilk olarak 1945 yılında 'işçi sigortalar kurumu' kurulmuştur. 1946 y1lında kabul edilen kanunlarla 'iş ve işçi bulma kurumu' ile Çalışma Bakanlığı kurulmuş, Basın ve Deniz İş Kanunlar çıkarılmıştır (Tokol, 2018: 66-68).

27 Mayıs 1960 tarihi, Türkiye'de sosyal politika açısından bir dönüm noktasını oluşturmaktadır. Nitekim bu dönemin anayasasında diğer anayasalardan farklı olarak ilk defa başlangıç bölümünde insan hak ve özgürlüklerine yer verilmiş, 2. Maddesinde devlet nitelik olarak; ulusal, demokratik, laik ve sosyal bir hukuk devleti olarak belirtilmiştir. Devletin, sosyal devlet olması nedeniyle anayasada çalışma hakkı, zorla çalıştırma yasağı, kadın ve çocukların çalıştırılması, dinlenme hakkı, ücrette adalet sağlanması, sosyal güvenlik, sağlık, konut, öğretim hakkı, kooperatifçiliğin gelişmesi, tarım ve çiftçinin korunmas ile ilgili düzenlemeler yapılmıştır. Böylece ilk defa sendika, toplu sözleşme ve grev hakk anayasa güvencesi altına girerek Batılı ülkelerden farklı olarak mücadele etmeden genis kapsamlı haklara kavuşmuştur. Dolayısıyla geniş bir kesime örgütlenme hakkı tanınmış, sendikaların faaliyet alanı genişlemiştir (Tokol, 2018: 69-70). Diğer taraftan bu dönemde uygulanan yasalarda bireyselliğin özgürlük adı altında politikalarda belirgin bir şekilde görüldüğünü de ifade edebiliriz (Özbay, 2017: 190). Örneğin bu dönemde 1965 'te çıkartılan Kat Mülkiyeti Yasasında (Resmî Gazete, 1965) "Tamamlanmış bir yapının kat, daire, is bürosu, dükkân, mağaza, mahzen, depo gibi bölümlerinden ayrı ve başlı başına kullanılmaya elverişli olanları üzerinde, o gayrimenkulün maliki veya ortak malikleri tarafindan,

bu Kanun hükümlerine göre, bağımsız mülkiyet hakları kurulabilir." ibaresi ile bir anlamda ev ve apartman kültüründe köklü bir değişime gidilmiştir. Bu uygulamadan sonra bir arada yaşamaların yerini, özel mülkiyetin getirisi olan bireysellik almıştır diyebiliriz (Özbay, 2017: 190). Diğer taraftan kalabalık aile evlerinin yerini geçici olarak ikamet eden kiracıların alması sonucu önceki dönemlerde komşu ailelerin bir aradaki halleri ile yardımlaşma ve dayanışmanın yerini, neredeyse birbirini tanımayan komşular almıştır. Bunun sonucunda komşuluk ilişkilerinin örselendiği, çocukların sosyalleşme sürecindeki komşuluk figürünün zayıfladığı veya olumsuz bir şekilde etkilendiği söylenebilir.

\section{Sonrası Sosyal Politikalar}

Bilindiği gibi Türkiye'de 12 Eylül 1980 tarihinde askeri bir darbe gerçekleşmiştir. Bu darbe ile birlikte neo-liberal politikalardan sonra sosyal politikalar bağlamında yeni bir dönem başlamıştır. Bu süreçte "siyasi partiler kapatılmış, sendika ve konfederasyonların bir bölümünün faaliyetleri durdurulmuştur" (Tokol, 2018: 71) Dolayısıyla 1982 Anayasa döneminin sosyal politikaları, dönemin siyasi konjonktüründen olabildiğince etkilenmiştir. Nitekim bu anayasa demokratik olmayan bir ortamda ve askeri rejim tarafindan atanan danışma meclisi taraftarlarınca ve asker gözetiminde oluşturulmuştur (Talas, 1992: 247). Ayrıca bu dönemde oluşturulan politikalardaki ana tema devlete addedilen kutsallıkla birlikte, devleti güçlendirmek, bireyi olabil- diğince kısıtlamak ve denetim altında tutmak olmuştur (Talas, 1992: 231). Daha sonraki süreçte, 06.11.1983 seçimleriyle birlikte yeniden çoğulcu demokrasiye geçilmişse de darbe sonrası iktidara gelen ANAP yaptığ politikalarla mevcut durumu değiştirememiştir ve bu durum bir süre daha devam etmişti (Tokol, 2018: 72).

1980’lerin sonundan 2000'li yıllara değin iş ve sosyal güvenlik konularında olmak üzere çalışma hayatını ilgilendiren konularda çeşitli değişiklikler yapılmıştır. 2003 tarihinde iş kanunda özellikle esneklik konusunda öneml yenilikler, dönem boyunca kadın ve engellilerle ilgili çeşitli düzenlemeler yapılmıştır Diğer taraftan "İş ve İşçi Bulma Kurumu" 25.06.2003 tarihinde 'IŞKUR' olarak yeniden yapılandırılmış ve 2012 yılında Sendikalar ve Toplu İş Sözleşmesi Kanunu kabul edilmiştir (Tokol, 2018: 72-73). Takip eden süreçte "2011 yılında 633 sayılı Kanun Hükmünde Kararname ile Aile ve Sosyal Politikalar Bakanlığı'nın kurulması ile yeni bir aşamaya girilmiştir" (Alper, 2018: 242). Sosyal politikalarda görülen bu denli büyük değişimlerin arka planında Türkiye'nin yeni bir kimlik kazanma, çağdaş yaşama ulaşma ve bütünleşme amacı bulunmaktadır. Bu girişimler sonucunda Türkiye'nin köklü değișimler içine girdiğini ifade edebiliriz (Talas, 1992: 305).

1980 Sonrası Aileye YönelikSosya Politikalar

Aile sahip olduğu işlevler nedeniyle toplumlar ve devletler için önemli bir kurum olagelmiştir. Bu nedenle devletler tarafindan uygulanan aile politikaları, toplum için önem teşkil eden bu kurumun desteklenmesi, ko- runması ve güçlendirilmesi gibi amaçlar güder (Aslan, 2018: 261).

Bununla birlikte devletlerin, sosyal güvenlik, vergi, sağlık, eğitim, barınma gibi alanlarda yaptığı politikalar aile ve aile yaşamı üzerinde dolaylı olarak etkili olsa da (Millar, 2011: 222-223) doğrudan aileyi konu edinen politikalar da mevcuttur. Aile politikaları olarak adlandırılan bu politikalar, diğer sosyal politikalardan farklı olarak, özellikle aile yaşamına etki etmeyi amaçlayan, devlet tarafından geliştirilmiş prensipler ve planlı süreçler sonucunda geliştirilmişlerdir. Dolayısıyla daha çok doğum hızı, aile büyüklüğü, çalışan ebeveynler için çocukların ve yaşlıların bakımına ilişkin hizmetler, koruyucu aile programları gibi konulara odaklanmış olan politikalardır (Barker, 1999'dan akt. İçağasioğlu Çoban ve Özbesler, 2009: 33). Bununla birlikte sosyal politikalar bağlamında doğrudan kadın, çocuk ve yaşlılara yönelik çok sayıda yasal düzenleme ve kanunlar da oluş̧urulmuştur.

Ülkemizde uygulanan 1980 sonrası politikalara baktığımızda 1982 Anayasasında ve daha sonrasında, aileye yönelik uygulanmış birçok sosyal politika bulunmaktadır. Ülkemizde aileye ilişkin hizmetler, Anayasa, Medeni Kanunu, Türk Ceza Kanunu, Sosyal Hizmetler ve Çocuk Esirgeme Kurumu Kanunu, Ailenin Korunmasına Dair Kanun ve Aile Mahkemeleri Kanunu çerçevesinde şekillenmektedir (İçağasioğlu Çoban ve Özbesler, 2009: 37). Bununla birlikte zamanla değişen veya düzenlenen yasalar da mevcuttur. Örneğin kadın haklarına yönelik olarak Anayasanın 10. maddesinde, "Kadınlar ve erkekler eşit haklara sa- 
hiptir." ibaresine "Devlet bu eşitliğin yaşama geçirilmesini sağlamakla yükümlüdür.” ibaresi eklenmiştir. Aynı şekilde Anayasanın 41. maddesinde ise "Aile, Türk toplumunun temelidi ve eşler arasında eşitliğe dayanır." şeklinde düzenleme yapılmıştır. 1985 yılında kadın konusu ilk kez bir sektör olarak 5. Beş Yıllık Kalkınma Planı'na konularak bu konuda politikalar belirlenmiştir. Bununla birlikte "1985 yılında Birleşmiş Milletler' in “Kadınlara Karşı Her Türlü Ayrımcılığın Önlenmesi Sözleşmesi (CEDAW) bazı çekincelerle kabul edilmiştir." Daha sonraki süreçte 1990 yılında Kadın Statüsü ve Sorunları Başkanlığı kurulmuştur. Başkanlık daha sonra müdürlüğe dönüştürülmüssse de 2004 yılında kurumla ilgili yasa çıkarılmı ve daha sonra Aile Sosyal Politikalar Bakanlığı'na bağlanmıștır. Diğer yandan kadınların çalışma hayatına dahil edilmesini konu alan kadınların çalıșmalarını kocalarının iznin bağlayan Medeni Kanunu'ndaki düzenleme 1990 yılında iptal edilmiş ve "2007 y1lında, Gelir Vergisi Kanununda yapılan değişiklikle hanehalkı içinde, kadınlar tarafından üretilen ürünlerin düzenlenen kermes, festival, panayı ile kamu kurum ve kuruluşlarınca geçici olarak belirlenen yerlerde satılması sonucu kadınların elde ettikleri gelirler vergiden muaf tutulmuştur.” 2003 yılında kadınların çalışma hayatında kadınların korunması ile ilgili kapsaml düzenlemeler yapılmış, eşitlik ilkesine özen gösterilmiş, negatif ayrımcılı̆̆ın kaldırılmas amaçlanmıştır. Ayrıca analık halinde çalıştırılma yasağı doğrultusunda doğumdan önce 8 , doğumdan sonra 8 hafta olmak üzere toplam 16 haftaya çıkarılmış, ihtiyaç duyulması halinde ise doğum sonrası izninin 13 haftaya çıkarılması sağlanmıştır (Aytaç, 2018: 346-349).
"Kadının istihdamını temel alarak düzenlenen iş-aile yaşamının uyumlaştırılması kapsamında kadınlara doğuma bağlı yarı zamanlı ve kısmi zamanlı çalışma imkanı verilmiştir. Yine aynı süreçte kadınların özlük hakları iyileştirilmiş, doğum yardımları yapılmış, belediyelere kreş açma zorunluluğu getirilmiş, babalık izni gibi uygulamalar planlanmıştır" (Akkuş Güvendi, 2018: 9). Bununla birlikte kadınların can güvenliğini sağlamak amaciyla Sosyal Hizmetler ve Çocuk Esirgeme Kurumu'na Bağlı Kadın Konukevleri Yönetmeliği 12 Temmuz 1998 tarih ve 23400 sayılı Resmi Gazete'de yayımlanarak kadın konukevleri uygulamasına gidilmiştir (Resmi Gazete, 1998).

Ülkemizde aile içinde değişimlere neden olan bir diğer olgu ise, cinsiyetler arasındaki farklara yönelik yapılan düzenleme ve uygulamalardır. Bu anlamda “Türkiye'de uzun bir geçmişi olan toplumsal cinsiyet eşitliğinin son yıllarda yasal çerçevesi genişletilmiş ve kadınların toplumdaki rolünü güçlendirmeyi hedefleyen devlet politikaları yaygınlaştırılmıştır. Bu kapsamda başta Anayasa'da olmak üzere Türk Ceza Kanunu'nda, Türk Medeni Kanunu'nda ve İş Kanunu'nda pek çok düzenleme gerçekleştirilmiştir” (Kadının Statüsü Genel Müdürlüğü [KSGM], 2008: 9). Daha önce de değinildiği gibi bu yasalarda cinsiyet farkından kaynaklı ayrımcılıkların ve farklılıkların kaldırılması hedeflenmiştir. Bununla birlikte "Türkiye'de toplumsal cinsiyet eşitliği politikalarının zeminini Cumhuriyet devrimleri oluşturmaktadır. 1923 yılında Cumhuriyetin kuruluşunu takip eden yıllarda, kadın-erkek arasında tam bir eşitlik olmaS1 gerekliliğine olan inançla gerçekleştirilen devrimlerle, bir yandan modern devlet yapısı oluşturulurken, öte yandan da büyük bir toplumsal değişim gerçekleştirilmiştir" (KSGM 2008: 13). Nitekim Osmanlı Devleti ile karşılaştırıldığında yapılan değişiklikler devrim niteliğindedir. Bununla birlikte ülkemizde (Kadınlara Karşı Her Türlü Ayrımcıllı̆ın Ortadan Kaldırılması Sözleşmesi [CEDAW]) İstanbul Sözleşmesi gibi toplumsal cinsiye eşitliğine ve aile içi şiddete karşı yapılan uluslararası politikalar da mevcuttur.

İstanbul Sözleşmesi adıyla bilinen ve 11 Mayıs 2011 tarihinde imzalanan ve ülkemiz de 2014 yılında yürürlüğe giren "Kadınlara Yönelik Şiddet ve Aile İçi Şiddetin Önlenmesi ve Bunlarla Mücadeleye İlişkin Avrupa Konseyi Sözleșmesi, uluslararası alanda kadın haklarını düzenleyen ve cinsiyet eşitliğini öngören belgelerin en önemlilerindendir (Aile Akademisi Derneği, 2019: 2). Bir diğer uluslararası düzeyde yasal açıdan bağlayıc bir sözleşme olan "Kadınlara Karşı Her Türlü Ayrımcılığın Ortadan Kaldırılması Sözleşmesi 1979 yılında kabul edilmiş ve 1981 y1lında yürürlüğe girmiştir" (Eroğlu, 2012 2). Bununla birlikte CEDAW sözleşmesi uluslararası düzeyde bağlayıcı bir sözleşme olduğundan dolayı Türkiye dört yılda bir komiteye sunulan ülke raporları ile değerlendirilmekte ve ülkedeki duruma göre tavsiye kararları vermektedir (KSGM, 2008: 17).

Toplumsal cinsiyet eşitliği mücadelelerinin elbette olumlu sonuçları bulunmaktadır Ancak aile içinde kadının değișen statüsü, bi rol karmaşasına yol açmakla birlikte diğer bireylerin rolleri ile çatışabilmektedir. Bunların yanı sıra aileyi dolaylı olarak etkileyen politi- kalar da mevcuttur. Örneğin gündüz bakımevi veya kreş hizmetleri çocukların psiko-sosyal gelişiminde işlevsel olmakla birlikte, kadının istihdama katılımı konusunda gizli işlevleri bulunmaktadır (Aslan, 2018: 267). Bu tür uygulamaların aile kurumunu ikincil bir pozisyona iten veya çeşitli işlevlerinin muadili olabilecek kurumların oluşumunu sağladığ görülmektedir. Böylece aile bireylerinin ayrı ayrı ya da yarı zamanlı olarak yaptığı işleri devralacak hizmetler ve aile dışı kurumsal yapıların oluşturulmasını (kreşler, çocuk yuvaları, koruyucu aile hizmeti, yaşlı bakımı gibi) öngören kurumların varlığı söz konusudur (İçağasıŏlu Çoban ve Özbesler, 2009: 36).

Aile politikalarının doğrudan konu edindiği diğer kesim ise çocuklardır. Çocuk bakımı, birçok ülkede aile politikalarının önemli konularından ve reform alanlarından biri olmuştur. Ülkemizde, 1982 yılında Mil-

li Eğitim ve Sağlık Bakanlığı birleştirilerek tek kamu kurumu olarak Sosyal Hizmetler ve Çocuk Esirgeme Kurumu (SHÇK) kurulmuştur. SHÇK çocuk koruma hizmetleri yanında diğer kamusal sosyal hizmetleri de şemsiyesi altına almıştır. 2011 yılında sosyal hizmetlere sosyal yardımlar da eklenerek çatı genişletilmiş ve Aile Sosyal Politikalar Bakanlığı kurulmuştur. Kurumun çocuk koruma misyonu sadece kurum bakımına muhtaç çocukları değil bütün çocuk nüfusunu kapsamayı hedeflemiştir (Karatay, 2016: 21-22). Yeni çocukluk anlayışının, Türk toplumunun modernleşme deneyimleriyle birlikte ortaya çıktığı ve çocuğu özne olarak kabul ederek çocuğa bu yönde değer veren bir yaklaşımı içerdiği görülmektedir (Tunca, 2018: 174). 
Bunun en önemli göstergesi olarak, yasalarla birlikte çocukların sahip oldukları haklardır (Tunca, 2018: 169). Çocuğa yönelik politikalar, kadın istihdamı, cinsiyet eşitliği, dogum oranları gibi birden fazla hedefe katkıda bulunan önemli bir uzlaşma unsuru olarak kabul edilmektedir. Demografik eğilimlerle (doğurganlık oranlarının düşmesi ve nüfusun yaşlanması) ilişkili olan bu politikalar, istihdam konusunda endişelere neden olmaktadır. Çünkü kadının çalışması, aile ile iş arasındaki uzlaşmazlıklara neden olmaktadır. Bu nedenle Türkiye'de özellikle 2010 sonrasında çocuk bakımı ve erken çocukluk eğitimi ile ilgili düzenlemeler yapılmıştır (Akkus Güvendi, 2018: 14). Diğer taraftan aile yapısında görülen değişimlerden dolayı yaşlılara yönelik politikalar da uygulanmıştır. Türkiye'de yaşlılar ile ilgili sosyal refah algısının biçimlenmesinde yaşlının içinde bulunduğu aile yapısının önemli bir etkinliği olmaktadır. Aile yapısının geleneksel veya modern biçimde olması, yaşlılara yönelik sosyal refahın algılanması ve uygulanması safhasında etkili birer değişken olabilmektedir. Modern zamanlar, sadece ekonomik anlamda bir dönüşüme neden olmamış, aynı zamanda sosyal bir dönüşüme de neden olmuştur. Bu sosyal dönüşümün en önemli merkezi "aile" kurumu olmuştur. Ailedeki dönüşüm, aile içinde bir fert olan yaşlı birey için de kaçınılmaz olarak bir dönüm noktası olmuştur. Geleneksel aile yapısı göz önünde bulundurulduğunda, yaşlının konum ve statüsü güvence altındaydı (Taşçı, 2017: 46). Ancak modern zamanda yaşlılar veya hastalar bir yük olarak görülebilmektedir. Bu anlamda son dönem sosyal politikalara baktığımızda yaşlı, hasta ve engelli bakımı için alt gelir gruplarındaki ailelerdeki kadınlara belirli bir ücret ödeyerek evde bakımı destekleyici bir politika benimsendiğini görmekteyiz. Maddi durumu kötü olan, yaşlı ve hastaların bu durumu tercih ettikleri genel bir kabuldür. Ancak bu durum bakım hizmetlerinin metalaşmasını beraberinde getirmektedir. Çünkü bu politika yaşlı bakımını yaşlı bireylerin hakkı olmaktan çıkartıp sadaka/ücret zihniyetine dayanan bir çözüm önermektedir (Özbay, 2017: 326).

Ülkemizdeki aile politikalarını değerlendirecek olursak, aileyi sürekli gelir sahibi yapacak istihdam politikalarının oldukça kısıtlı olduğu görülür. Aileye yönelik yapılan sosyal yardımların ise son derece dağınık, geçici ve bağımlı kılıcı olduğu ifade edilebilir. Dolayısıyla üretim merkezi olan aile tipinden tüketici aile tipine geçilmiştir. Ülkemizde kapsayıcı ve bütüncül bir aile politikasının olmamasının çeşitli nedenleri bulunmaktadır. Bunların başında politikalarımızın taklidi/ ithal olması gelir. Bir diğer nedeni ise hükümetin sürekli değişmesi, kalıcı aile politikalarının yapılamaması ve popülist politikaların öne çıkmasıdır. Bununla birlikte, politika yapan siyasiler ile alanın uzmanı olan akademisyenler arasındaki iletişim kopukluğu da önemli nedenlerdendir (İçağasıŏlu Çoban ve Özbesler, 2009: 37-39).

\section{Sosyal Politikalarla Beraber}

\section{Değișen Aile}

Aile sadece bir sosyalizasyon veya yeniden üretim aracı değildir; aile, kendisine toplum dediğimiz yapıyı inşa eden önemli unsurlardan biridir (Aytaç, 2012: 11). Bu nedenle devletler zaman zaman özellikle aileye yönelik çeşitli hizmet, politika, yasa ve düzenlemeler oluşturur. Daha önce de değinildiği gib Sanayi Devrimi sonrasında sosyal devlet anlayışından ötürü devletler aile kurumu üzerinde doğrudan etkili olmaya başlamışlardır. Dinamik bir yap1 arz eden aile kurumu uygulanan politikalardan dolayı çeşitli şekillerde etkilenmiştir. Ülkemizde ve dünyada 19. yüzyılın son çeyreğinden itibaren, özellikle iş ve çalışma olanağı bularak sınai tesislerin çevresindek kentlere yerleşenlerin yaşam ve çalışma koşullarının beraberinde getirdiği birçok risk için sosyal güvenlik hizmetlerinin daha sistemli ve organize biçimde yürütülmesi gereği, bu görevi yerine getirecek yeni müesseseler ortaya çıkmıştır (Koyuncu, 2013: 357- 358) Yapılan bu değişimler devlet eliyle gerçekleşmiş, toplumun ve ailenin güçlenmesini hedeflemiştir. Ancak her zaman istenilen şekilde aile üzerinde etkili olunamamıştır. Örneğin aile-içi ilişkiler ve sorumluluklarda kadın-erkek eşitliği fikri popülerlik kazanmakla kalmamıs annenin çoğu durumda artık babanın rolünü de üstlendiği yeni bir resim doğmuştur. Bu durumda baba, aile içinde bir rol erozyonu yaşarken, çocuk ailede merkezi bir rol edinmeye başlamıştır. Bu durum, çocuk hakları söyleminin yasal ve siyasal bir destek kazanmasiyla da pekişmiştir. Çocuk hakları yönelimi bir anlamda çocukluğun yeniden tanımlanmasını gerektirmekte ve çocuklukla yetişkinlik arasındaki farkları silici bir özelliğe sahip olabilmektedir. Çünkü bu yönelimde çocuklar artık ailelerine bağımlı küçükler olarak görülmek yerine ebeveynlerinden farklı kendi hakları ve çıarları olan otonom birer birey gibi ele alınmaktadır (Çakı, 2016: 285-286).

1980'li yıllar dünyada hızlı değişimlerin yaşandığı dönüşümlere tanıklık etmiştir. $\mathrm{Bu}$ dönemde meydana gelen değişimler, kadının ve ailenin konumunun da değişimini beraberinde getirmiştir. Son yıllarda, ailenin anlamının, geleneksel tanımının ötesine geçerek daha geniş bir anlam taşıdığına yönelik düşünceler hakim olmaya başlamıştır. Geçmişte evli çiftler evlilik süreci boyunca birbirlerinden çok şey beklememişlerdir ancak günümüzde bireylerin evliliklerine ilişkin beklentilerinde değişimler meydana gelmiştir. Bunun yanı sıra, kadının işgücü piyasasında geçmişe nazaran daha çok yer almaya başlaması erkeğe olan ekonomik bağımllık durumunu ortadan kaldırdığı için daha farklı yaşam biçimlerinin ortaya çıkmasına neden olmuştur (Köse, 2018: 31-33). Diğer taraftan "boşanma oranlarının yükselmesi, tek ebeveynli aile sayısının artması, çocukla ilgili toplumsal kabullerin değişmesi ve doğurganlık oranının düşmesi, bireyciliğin ön plana çıkıp bağımsız yaşama isteğinin genel geçerlilik kazanması ve ailenin daha da küçülmesinin sonuçları olarak, geleneksel aile yapısının son 30-35 y1llı periyotta önemli bir değişim geçirdiği görülmektedir" (Akgeyik, 2006'dan akt. Taş̧̧ı, 2017: 47).

Zamanla hayat koşullarının gelişmesi ve iyileşmesi ile birlikte tüm dünyada hayatta 
kalma süresi ve yaşlı nüfus artmıştır. Bununla birlikte geleneksel geniş ailenin yerini aile üye sayısının azaldığı çekirdek ailenin almasıyla birlikte değişen aile yapısı, yaşlıların aile içindeki konumlarını da değiştirmiştir. Geleneksel yapı, yaşlıların aile içindeki bakımını sağlamıştır ancak ailenin küçülmesi, yetişkin çocukların yaşlılara bakma imkanlarını azaltmıştır. Bu durum, zaman içinde yaşlıların sorumluluğunu üstlenecek kişilerin oranlarının azalmasına neden olmuştur. $\mathrm{Bu}$ nedenle yaşlıların çeşitli ihtiyaçlarını karşılayacak kurumlara ihtiyaç doğmuştur. Yaşlılara yönelik oluşturulan sosyal politikalar, bu tür kurumların hizmet vermesini ve yaygınlaşmasını sağlayabilir. Ancak bu uygulamaların da ailede bir değişime neden olması muhtemeldir. Nitekim bu kurumların yaygınlaşmas1, toplumda daha önce görülmeyen, yaşlılara yönelik tutumları şekillendirmekte ve top lumun yaşlı algısını değiştirmektedir. Geleneksel aile yapısından çekirdek aile yapısına doğru meyleden bir dönüşüm neticesinde, (çekirdek) ailenin bir sosyal refah kurum olma özelliğini önemli bir düzeyde kaybetmeye başladığı görülmekte ve dolayısıyla 'yaşlı' aile içinde 'sorumlu' statüsündeyken 'sorunlu' statüsüne evrilmesine neden olmuştur (Taş̧̧ı, 2017: 47).

Modernleşmenin bir sonucu olarak artan kentleşme aileyi çeşitli açılardan etkilemis boşanmalara zemin hazırlamıştır. Dolayısıyla aile mefhumu kentlerde daha zayıftır. Bununla birlikte geleneksel toplumlarda evlilik bir sosyal güvence olarak algılanmaktadır. Kadın, evde ev işlerini yapar; erkek çalışır, kazanır ve aileyi korur. Modern toplumlarda ise her bireyin sosyal güvencesi vardır. Dolayısıyla bireylerin başka bireyler tarafından korunmaya ihtiyacı yoktur. Huzursuzluğa ve şiddete maruz kalındığı zaman, evliliği sona erdirme konusunda daha rahat karar verilebilmektedir. Modernleşmenin getirdiği tüm bu değişiklikler ve elde edilen haklar kadınların açtığı boşanma davalarının sayısını arttırmaktadır diyebiliriz (Aybey, 2017: 110-111).

Kadın nüfusunun istihdamının artması geleneksel evlilik ilişkilerinin değişimini tetiklemiştir. Eskiden kadının daha çok ev işlerinden sorumlu olması ve erkeğin ise daha çok araçsal rolleri yerine getirerek dışarıda çalışması, kadının iş hayatına girmesiyle birlikte değişmiştir. Kadın, bir yandan ev işlerine yetişmekte bir yandan dış hayata uyum sağlamakta ve bu iki alan arasında stresli bir yaşam sürmeye çalışmaktadır. Dolayısıyla iş ve aile arasında sıkışan kadın için bugün gelinen noktada aile kurumu, bir sığınak olmaktan çıkmıştır (Gittins, 2011: 9). Hatta kimi zaman eşi veya çocuklarıyla mücadele ettiği, kızıştığı bir alan haline gelebilmektedir. "Kadınların iş gücüne katıl1$\mathrm{m} 1$ ve boşanma arasında pozitif bir ilişki gören düşünürlerin yanı sıra boşanmanın da işgücüne katılımı tetiklediği yönünde çalışmalar bulunmaktadır. Özellikle boşanma riski karşısında kadınların iş gücüne daha fazla katıldığı kendini güvence altına almaya çalıştı̆g da iddia edilmektedir" (Timurturkan, 2018: 207-208).

Günümüzde yalnızca erkeğin (mesleki anlamda) çalıştığı aile yapısından, kadının da çalışmaya ortak olduğu bir aile yapısına geçişin olduğu görülmektedir. Kadınların eğitim ve iş yaşamına katılımlarına paralel olarak geleneksel aile içi roller ve davranış kalıpları değişmektedir. Yapılan yasa ve düzenlemeler sonucunda kadın istihdamı artmıştır. Bunun sonucunda kadınlar aile bütçesine katkıda bulunuyor olsa da kadının ev içindeki rollerinde bir değişim olmamış ve bu durum kadının ev içindeki yükünü arttırmıștır. Dolayısıyla çocuk sahibi olmak, kadının günlük yaşantısını doğrudan etkilediği için kadının is ve aile hayatı arasında bir tercihte bulunmaya yöneltmektedir. $\mathrm{Bu}$ anlamda yapılan teşvik edici politikalar beraberinde yeterli ve nitelikli kamusal düzenleme ve desteği getirememektedir. İş-aile yaşamının uyumuna yönelik yapılan politikalar ise daha çok istihdam odaklı ilerlemektedir. Bu durum ise kadınlar açısından iş-aile çatışmasını arttırmaktadı (Akkuş Güvendi, 2018: 23). Bununla birlikte sanayileşmenin yaşandığ hızla kentlere göç ederken kentlerde sosyal hayat zorlaşmıștır. Nüfus yoğunluğu sanayileşmeyle birlikte kısa sürede fabrikaların bulunduğu kentlere kaymıştır. Tarım toplumlarındaki aile yapısı çözülmüş, geniş ailelerin yerini çekirdek aileler almıştır. Dolayısıyla geniş ailenin aile üyelerine yönelik, güvenlik sağlama ve toprağı işlemede işgücü sağlama fonksiyonu ortadan kalkmıştır (Köse, 2018 19-20). Geleneksel aile yapısından modern aile yapısına doğru bir dönüşüm geçirmekte olan aile yapımızdan dolayı (Ulutaş ve Özpınar, 2013: 395) aile bireylerinin gittikçe daha çok bireyselleşmesi, hedef ve arzularına daha fazla odaklanması nedeniyle aile bağlarının zayıfladığı görülmektedir. Aile bağlarının zayıflaması ise bireylerin, kendilerini aile bağlarını sürdürmekle daha az yükümlü hissetmesine neden olmaktadır (Millar, 2011: 225) Diğer taraftan "geniş aileden çekirdek aileye geçişle birlikte dini inanç, düşünce ve yaşamda da bazı değişimlerin olduğu görülür." Geleneksel geniş ailelerde dini inanca dayalı olarak bulunan biz duygusu modern çekirdek ailede yerini ben duygusuna bırakmıştır. Dini değerler geniş ailelerde kolektivist bir karakter taşırken çekirdek ailelerde bireysel bir şekle dönüşmüştür (Akdoğan, 2019: 255-256). Bu dönüşümle birlikte toplumsal anlamda süregelen algıda biz duygusunu besleyen kaynakların yaşanan değişimle birlikte etkisini yitirebildiği görülmektedir.

Çalışan kadınların diğer bir sorunu ise doğum izninin yetersizliği ve yeteri derecede çocuklarına annelik yapamamasıdır. Çalışan kadınların 8 hafta doğum öncesi, 8 hafta doğum sonrası olmak üzere toplam 16 hafta doğum izni bulunmaktadır. Ayrıca doğum izninden sonra mesai saatleri içinde süt izni ya da iki yıla kadar ücretsiz izin hakları da bulunmaktadır. Ancak bu izinlerin yeterli olmadığı da görülmektedir. Çünkü annenin tüm izin haklarını kullandığı düşünülse bile çocuklar iki yaşından itibaren kreşlere ya da bakıcılara teslim edilmektedir. Bu durum ise güvensiz, azami anne sevgisinden mahrum ve kendini gerçekleştiremeyen çocukların yetişmesini beraberinde getirmektedir. Ayrıca kadınların çoğunluğu ücretsiz izni ya kullanmamakta ya da çok az kullanmaktadır (Can, 2013: 234-235). Bu durum aile içindeki psikolojik durumun vahametini göstermektedir. Ailenin temel işlevi bireyin psikolojik gelişimini ve sosyolojik ihtiyaçlarını karşılamaktır. Aile, bireyin psikolojik ihtiyaçlarını karşılamada ve kimlik oluşturmasında etkili olduğu gibi öğrettiği rol ile de aile içinde bir statü kazandırır. Birey toplumsal 
yapı içinde rol ve statü kazanmayı da temelde aileden öğrenir. Aile özellikle bireyi koruma altına alma, aile yuvası içinde ona güven duygusu verme ve böylelikle toplumun kültürünü ve değerlerini ona aktararak sosyalleşmesini sağlamak suretiyle topluma doğrudan etki eden en temel kurumlardan biridir. Buna karşın toplumsal yapı, her toplumda temel bir öğe olma özelliğini koruyan aileyi etkisi altına alır (Birekul, 2013: 289). Böylece iş yaşamına katılan kadınların aile üyeleriyle geçirdikleri süre azalmaktadır. Bu nedenle özellikle çocukların anneleriyle geçirdikleri zamanı kısıtlamaktadır. Çocukların aile içindeki eğitimi büyük oranda annelere aitken kadının iş hayatına dahil olmasıyla beraber çocukların daha küçük yaşlardaki eğitimi de eğitim kurumlarına ak tarılır hale gelmiştir (Altunsu Sönmez, 2013 310-311).

Modern dönemle birlikte toplumsal yaşamın her alanında yaşanan kırılmalar aile kurumunun değişmesine, yeni biçimler kazanmasına, kimi rollerini kaybetmesine ve kimi yeni roller kazanmasına neden olmuştur. "Endüstrileşme, değișen iş yaşamı, kadın ve erkeğin iş gücüne katılım oranının artması, kent yaşamında ilişkilerin değişmesi, artan bireyselleşme, liberalleşme, aile ve evlilik ilişkilerinin yeni biçimler kazanması, değişimin temel itici gücü olmuştur.” Bununla birlikte, bireyselleşmenin yanı sıra, artan hukuki haklar, ahlaki ve kültürel değerlerin değişmesi ve boşanmanın toplumsal kabulü de boşanmaların artmasında önemli bir faktör olmuştur (Timurturkan, 2018: 201-202) Çeşitli yasa ve düzenlemelerle kolaylaștırılan boşanma olgusu beraberinde çoğu zaman geri döndürülmez sonuçlara sebep olmuştur. “Modern/Endüstriyel toplumlarda 1960'11 yıllardan itibaren sıklıkla ailenin çöküşünden bahsedilmeye başlanmıştır. Aile değerlerinin çözüldüğü sıkça dile getirilmiştir. Özellikle boşanmaların artışı ile ortaya çıkan tek ebeveynli aileler, çocuklar açısından model almada sorunlar yaratmaktadır. Bu ailelerin, suçun artışı, eğitimde başarısızlık ve çalışmaya ilgisizlik gibi sonuçlara yol açtığı ileri sürülmektedir." (Bozkurt, 2013: 269-270) Ayrıca büyürken ebeveyn eksikliğinden kaynaklı rol model karmaşası yaşayan çocuklarda ileriki yaşlarda cinsel eğilimlerin değişmesi de muhtemeldir. Bununla birlikte boşanma sonrası uygulanan bazı yaptırımların, boşanan çiftler ve çocuklar üzerinde olumsuz etkileri olabilmektedir. Örneğin son zamanlarda oldukça gündemde kalan ve iki milyon erkeğin süresiz nafaka ödemesi nedeniyle mağdur olmaları tartışılmıştı. Uygulanan bu yasada henüz tam bir çözüm oluşturulamadı (Haberler.com, 2019). Bu uygulamanın, boşanan erkekleri, maddi anlamda zor durumda bıraktığ 1 için yeni bir aile kurmalarını engellediği görülmektedir. Dolayısıyla bir aile politikasının aile kurumunu sekteye uğratması dahi mümkündür. Son zamanlarda ülkemizde tartışılan ve birçok ailenin mağdur olmasına neden olan başka bir politika gündemde yer edindi. Buna göre erken yaşta yapılan evlilikler 'resmi nikah' olmasına rağmen binlerce eş tecavüz suçuyla yargılanıp cezaevine konuldu. Bu nedenle çok sayıda aile parçalandı, çok sayıda kadın mağdur oldu (Milli Gazete, 2019). Görüldüğü gibi aile yararı gözetilerek uygulanan bazı politikalar amaçlandığı şekilde sonuçlanmayabilmektedir.
Sosyal politikalarla birlikte aile içerisindeki değişimden etkilenen bir diğer kesim ise yaşlılardır. Daha önce değinilen yaşlılara yönelik politikalar tartışmalı bir konudur. Yaşlıların evde bakımı konusu önceki toplum yapımızda diğer aile bireyleri için bir görevdi. Ancak bu görevin bir ücrete tabi tutulmas yaşlılara yönelik algıyı değiştirebilmektedir Bununla birlikte devlet tarafından verilen bu yardımı aşağılayıcı bulan yaşlılar da vardı (Dural ve Con, 2011: 490). Diğer bir açıdan bakıldığında ise ailedeki kadın üyelere bakım yaptıkları için ücret vermek, kadınların ve yaşlı bireylerin torunlarının kendi kültürel sermayelerini geliştirebilecek olanaklar kısıtladığı ve yaşlandıklarında zor koşulla altında yaşama risklerini arttırdığı görülü (Özbay, 2017: 326-327).

Bugün gelinen noktada aile yapımızın bi değişim geçirdiği ve hala değişmekte olduğu açıktır. Bu değişimi daha iyi anlayabilmek için bazı istatistikî verilere bakmamız gerekir. Türkiye İstatistik Kurumu [TÜIK]'ten alınan verilere göre evlilik yaşı yıllara göre gittikçe yükselmek tedir. Nitekim TÜiK'in 'Evlenme ve Boşanma İstatistikleri’ araştırmasında 2001 yllındaki ilk evlenme yaşı kadınlarda 22,7 erkeklerde 26,0 iken 2020 yılında bu veriler yükselerek, kadınlarda 25,1 erkeklerde ise 27,9 olmuştur (TÜIK 2021b). Dolayısıyla yıllara göre ilk evlenme yaşının her iki cinsiyette de yükseldiği görülmektedir. İlk evlenme yaşının artması demografik oranlar üzerinde olumsuz etkide bulunmaktadır. Çünkü ilk evlenme yaşı yükseldikçe doğurganlık oranı da azalmaktadır. Nitekim doğum yapan annelerin yaş ortalaması da 2001 y1lında 26,7 iken 2020 yılında 29,0 olmuştur (TÜIK, 2021c).
Aile yapısında görülen bir diğer değişim ise hanehalkı büyüklüğüdür. TÜIK' in yayınlanan 'İstatistiklerle Aile, 2020' adlı çalışmasında görülen istatistiki verilere göre ortalama hanehalk1 büyüklüğü, 2008 yılında 4,00 iken 2014'te 3,6; 2018 yllında 3,4 ve 2020 yılında 3,00 olmuştur. Bu verilere göre bir ailede bulunan ortalama kişi sayısı gittikçe azalmıştır. Bununla birlikte tek kişilik hanehalk1 oranı 2014 'te \%13,9 iken 2018 yılında $\% 16,1$ ve 2020 yılinda ise \%17,9 olarak artmıştır. Yine aynı rapora göre yalnızca anne ve çocuklardan veya yalnızca baba ve çocuklardan oluşan çekirdek aile sayısı da yıllara göre artmıştır (TÜIKK, 2021a).

Aile yapımızda göze çarpan bir diğer değişim ise doğurganlık hızıdır. "Toplam doğurganlık hızı, bir kadının doğurgan olduğu dönem (15-49 yaşları arası) boyunca doğurabileceği ortalama çocuk sayısını ifade eder." (TÜIK, 2021c) Ülkemizdeki doğurganlık hızı yıllar içinde çeşitli dönemlerde azalmış veya artmıştır. Ancak 2014 yılından itibaren aşamalı olarak azaldığ 1 görülmektedir. $\mathrm{Bu}$ konudaki istatistiklere baktığımız zaman, 2001 yılında 2,38 olan doğurganlık hızının 2020 yılında 1,76'ya kadar gerilediğini görmekteyiz (TÜİK, 2021c)

Ülkemizde doğurganlık hızının yanında görülen bir diğer demografik değişim ise kaba doğum hızıdır. "Kaba doğum hızı, belirli bir bölgede belirli bir süre içinde gerçekleşen doğumların o süre ortasındaki nüfusa bölünmesiyle bulunan ve binde olarak ifade edilen bir hızdır" (H Sözlük, 2016). Ülkemizde gittikçe azalan bir kaba doğum süreci olduğunu ifade edebiliriz. 
Nitekim 2001 y1lında \%o 20,3 olan bu oran 2020 yılında \% 13,3 olmuştur (TÜİK, 2021c)

Toplum için büyük önem taşıyan aile kurumunun oluşabilmesi için büyük önem taşıyan evlilik oranında da azalmalar görülmekte ve aile kurumunun parçalanması sonucu gerçekleşen boşanma oranında da artmalar görülmektedir. TÜIK (2021b)'den alınan istatistiklere göre 2010 yılında kaba evlenme hızı \%o 7,97 iken 2020 yılında \% 5,84 olmuştur. Yine aynı araştırmada kaba boşanma hızı 2010 yılında \%o 1,62 iken 2019 yilında \%o 1,90 olmuştur.

İstatistiki verilerden de anlaşılacağı üzere aile yapısında görülen birtakım değişimle mevcuttur. Azalan evlenme ve kaba doğum oranları ve yükselen ilk evlenme yaşı, ileride artacak olan yaşlı nüfusun ve azalacak olan genç nüfusun habercisidir. Diğer taraftan artan boşanma ve tek ebeveynli aile sayısı hem çocuk hem de eşler için psikolojik anlamda yıpratıc bir durumdur. Mutsuz ebeveyn ve çocukların oluşturduğu aile profili ise zinde ve güçlü bir toplum profiline ters düşmektedir. Bu ise gelişmekte olan bir ülke için olumsuz bir durumdur

Bununla birlikte ifade edilmesi gereken bir diğer durum ise ülkemizdeki aile profilinde yaşanan değişimlerin Batıdaki aile profilinde görülen değişimden farklı olduğudur. Çünkü aile yapımızda her ne kadar birtakım değişim veya çözülmeler meydana gelmişse de Türk kültüründe aileye verilen önem ve din kaynaklı sıla-i rahim anlayışından dolay çekirdek ailenin akraba, hısım veya hem şehri ile yakın etkileşimleri varlığını korumaya devam etmiştir (Koyuncu, 2013: 375). Yaşanan değişimlere rağmen korunan değerlerin olması umut verici olsa da bu konuda daha dikkatli olunması gerekmektedir. Bu nedenle aileye yönelik yapılacak politikalarda kalıcı ve yapıcı nitelikte olan, toplumsal değerleri göz önünde bulunduran ve "aile içindeki genç, kadın, yaşlı vb. farklı bireylerin sorunlarını çözmeye çalışan bütüncül yeni sosyal politikalara ihtiyaç vardır” (Aysan, 2016: 305).

Sonuç

$\mathrm{Bu}$ çalışmada sosyal politikaların, aile üzerinde doğrudan ve dolaylı bir şekilde oluşturduğu değişim ve dönüşümler saptanmaya çalışıldı. Bu nedenle öncelikle sosyal politikanın tanım, kapsam ve işlevlerine ve ortaya çıkış sürecine değinildi. Daha sonra ülkemizdeki sosyal politika süreci ve işlevi aktarılarak toplumumuzdaki sosyal politika olgusu anlaşılmaya çalışıldı. Bu anlamda ülkemizde uygulanan sosyal politikaların köken itibariyle çeşitli ideolojik kaygılara dayanarak Batıdan alındığı sonucuna varıldı. Daha sonra ülkemizde gerçekleştirilen 1980 sonrasında uygulanan ve özellikle aile üzerinde etkisi olan, aile, kadın ve çocuk konulu sosyal politikalar genel bir çerçeve içerisinde aktarılmaya çalışıldı. Bu politikaların aile yapısı üzerinde doğrudan veya dolaylı olarak etkili olduğu fikri üzerinde durularak aile yapımızda görülen değişimler ve bu değişimlerin toplumsal yapıyı nasıl etkilediği tespit edilmeye çalışıldı. Bu doğrultuda TÜIKK tarafindan yayınlanan verilerden yararlanılarak, özellikle son yılların boşanma oranı, evlenme oranı, kaba doğum oranı, tek ebeveynli aile sayısı gibi veriler yıllara göre analiz edildi.
Sonuç olarak modernleşme ve küreselleşme süreçlerinin etkisiyle, dünyada siyasi, sosyal, ekonomik ve kültürel alanlarda köklï değişimler yaşanmıştır. Sosyal politikaların da etkisiyle aile kurumu bu değişimlerden büyük ölçüde etkilenmiştir. Daha önce birçok ihtiyacını üretebilen ve aile bireyler için güven ortamı sunan aile, yapı itibariyle parçalanmış, güven veren profilinden uzaklaşmış ve neredeyse tüm ihtiyaçlarını dışarıdan karşılayan dışa bağımlı bir yapıya bürünmüştür. Kent yaşamının da beraberinde getirdiği kadın istihdamının artması ve bunun politikalarca desteklenmesi aile içindeki kadın rolünü olumsuz anlamda etkilemis ve aile içinde çeşitli rol çatışmalarına sebep olmuştur. Kadının iş ve ev arasında yaşadığ1 çatışmalar kadın üzerinde baskı ve stres oluşturmuştur. Diğer taraftan artan ev yükü nedeniyle aile bireyleri ile geçirdiği süre azalmıştır. Bununla birlikte ailenin çeşitl işlevlerini kısmen yerine getiren kurumların politikalar dahilinde oluşturulması, ailenin toplumsal ve bireysel anlamda yerine getirdiği önemli birçok işlevini bu kurumlara devretmesine neden olmuştur. Bu kurumların ailenin çeşitli işlevlerini yerine getirmesi zaman zaman ihtiyaçlara cevap veriyor olsa da aile kurumunun muadili bir pozisyonda yer alması, aile kurumunun işlevleri bakımından vazgeçilmez bir kurum olduğu algısına hasar verebilmektedir. Nihayetinde çocuk ve yaşlı bireyler için birçok anlamda elzem olan aile böylece yeniden tanımlanmıştır. Aile olgusu içerdiği anlam itibariyle zayıflamış, içinde adeta gelir-gider hesabının en iyi şekilde yapılması amacıyla içinde yaşanılan bir mekana dönüşmüştür diyebiliriz.
Ebeveynlerinin gün boyu çalıştığı ailelerde, çocuklar küçük yaşta kreş ve gündüz bakım evlerine emanet edilmekte, yaşlılar ise aile ortamından izale edilerek, genelde şehrin dışında konumlanan yaşılı bakım evlerine terk edilmektedir. Bu gibi durumların, hâlihazırda ailenin varlığı söz konusu iken gerçekleşmesi, yaşlı ve çocuklar için psikolojik anlamda olumsuz sonuçlar doğurabilmektedir. Devlet eliyle ihtiyaç sahibi ailelerin desteklenmesi amacılla yapılan maddi yardımlar ise sorunu çözmek ve aileyi otonom bir kuruma dönüştürmek yerine kurumlara bağımlı hale getirebilmektedir.

Görüldüğü gibi sosyal politikalar aile ve toplum yapısı üzerinde doğrudan ya da dolaylı bir şekilde etkili olmuş ve olmaya devam etmektedir. Geldiğimiz noktada geniş aile yapımız çekirdek aileye evirilmiş hanehalkı sayımızda azalma meydana gelmiştir. Diğer taraftan boşanma oranları artmış buna bağlı olarak tek ebeveynli aile sayısında da artışlar gözlemlenmiştir. Nüfus artış oranı ve kaba doğum hızı gibi demografik verilerde düşüşler gözlemlenmiştir. Ancak yaşanan değişimlere rağmen toplumsal yapımıza bağ11 olarak aile kurumu önemini ve varlığını sürdürmeye devam etmektedir. Ailenin bu varlığını ve önemini koruyabilmesi için uygulanan politikaların yapıcı, çok boyutlu ve kapsamlı olmasına dikkat edilmeli, gerektiğinde aile özelinde ilgilenilmeli ve mahalli çözümler üretilmelidir. 


\section{Kaynakça}

Aile Akademisi Derneği, (2019). “İstanbul Sözleşmesi İle İlgili Kafa Karıştıran 10 Soru-10 Cevap", www.aileakademisi.org arastirma/istanbul-soezlesmesi-ile-ilgili-kafa-karistiran-10-soru-10-cevap Erişim tarihi 10.06.2020

Akdoğan, Ali (2019). Din sosyolojisi, İstanbul: Ensar Neşriyat.

Akkuş Güvendi, Merve. (2018). Karșılaştırmalı Bir Perspektiften Türkiye'de Aile Politikaları, İlke Politika Notu/8. (s, 3-26) https://ilke.org.tr/images/yayin/pdf/karsilastir mali_bir_perspektiften_turkiyede_aile_politikalari.pdf Erişim Tarihi: 20 Nisan 2020

Alper, Yusuf (2018). "Sosyal Güvenlik", Sosyal Politika (9. Baskı) içinde, Ed. Aysen Tokol ve Yusuf Alper, Bursa: Dora Basim-Yayın, s.210-254.

Altan, Ömer Zühtü (2007). "Sosyal Politika Bilim Dalı", Sosyal Politika içinde, Ed. Ömer Zühtü Altan, Eskișehir: Anadolu Üniversitesi Yayınları s.1-19.

Altunsu Sönmez, Özlem (2013). “Ailenin Diğer Kurumlarla İlişkisi”, Sistematik Aile Sosyolojisi içinde, Ed. Mustafa Aydın, Konya: Çizgi Kitapevi s.293-314.

Aslan, Senem (2018). "Değișen Dünyada Aile Politikaları", Değişen Toplumda Değişen Aile (Sosyolojik Tartışmalar) içinde, Ed. Nurşen Adak, Ankara: Siyasal Kitapevi, s.261-279.

Aybey, Salih (2017). "Dünden Bugüne Modernleşme Bağlamında Ailenin Değiş̧im ve Dönüşümü”, Aile ve Modernite içinde,
Ed. Salih Aybey, Murat Akın, ve Tahyr Ashyrov, Ankara: Bülent Ecevit Üniversitesi Yayınları s. 103-118. https://docplayer.biz. tr/138692726-Bulent-ecevit-universitesi-yayinlari-no-19-aile-ve-modernite-editorler-salih-aybey-murat-akin-tahyr-ashyrov.html Erișim tarihi: 23.10 .2020

Aysan, Mehmet Fatih (2016). Türkiye'de Demografik Değişim ve Aile Yapıları Ed. B. Kıran, içinde: İnsan ve Medeniyet Hareketi Sempozyumu Dizisi / Toplumsal Değişim, İstanbul, s. 305-321. http://www.tde.org.tr/ tds_2016_kitap.pdf Erişim tarihi: 11.05.2020.

Aytaç, Ahmet Murat (2012). Ailenin Serencamı: Türkiye'de Modern Aile Fikrinin Oluşması. Ankara: Dipnot Yayınları.

Aytaç, Serpil (2018). “Çalışma Hayatında Özel Gruplara (Dezavantajlı) Yönelik Sosyal Politikalar", Sosyal Politika içinde, Ed. Aysen Tokol ve Yusuf Alper, Bursa: Dora Basim Yayın, s. 327-354.

Bedir, Eyüp ve Bülbül, Okan Güray (2018). "Sosyal Politikaya İlişkin Genel Bilgiler ve Sosyal Politikanın Araçları”, Sosyal Politika içinde, Ed. Abdurrahman İlhan Oral ve Yener Şişman, Eskişehir: Anadolu Üniversitesi, s. 2-27.

Birekul, Mehmet (2013). "Aile - Toplum İlişkisi”, Sistematik Aile Sosyolojisi içinde, Ed. Mustafa Aydın, Konya: Çizgi Kitapevi, s. 271-292.

Bozkır Serdar, Aysu (2018). "Sosyal Politika Kavramı, Tarihsel Gelişimi ve Türkiye'de Sosyal Politika", Sosyal Politika (9. Bask1) içinde, Ed. Aysen Tokol ve Yusuf Alper, Bursa: Dora Basım Yayın s. 1-78.
Bozkurt, Veysel (2013). Değișen dünyada sosyoloji temeller kavramlar kurumlar. Bursa: Ekin Yayınları.

Can, İslam (2013). “Tarih Toplum ve Kültür Bağlamında Aile ve Kadın”, Sistematik Aile Sosyolojisi içinde, Ed. Mustafa Aydın, Konya: Çizgi Kitapevi, s.215-248.

Çak1, Fahri (2016). "Farklılaşan Dünyada Aile Politikaları ve Ailenin Geleceği”, Aile Sosyolojisi içinde, Ed. Nazmi Avcı ve Erda Aksoy, İstanbul: Lisans Yayınc1lık, s, 275 311

Dural, Baran ve Gülçin. Con (2011). "Türkiye'de Sosyal Devlet ve Yaşlı Haklan Üzerine Bir İnceleme", Sosyal Haklar Uluslararası Sempozyumu Bildiri Kitabı içinde Petrol İş Yayını, s. 483-490. https://docplayer.biz.tr/1870624-Turkiye-de-sosyal-devlet-ve-yasli-haklari-uzerine-bir-inceleme html Erişim tarihi: 20.10.2021.

Eroğlu, Feride (2012). Yakın Dönem Anayasalarında Toplumsal Cinsiyet ve Kadın Erkek Eşitliği ile İlgili Düzenlemeler, Ankara: TBMM Araştırma Hizmetleri Başkanlığı. https://anayasa.tbmm.gov.tr/docs/yakindonemanayasa4may.pdf Erişim Tarihi: 3 Mart 2019

Gittins, Diana (2011). Aile Sorgulanıyor. (Tuna Erdem, Çev.) İstanbul: Pencere Yayınlar1.

Haberler.com, (2019) https://www.haberler.com/suresiz-nafaka-magdurlari-platformu-aciklamasi-11644483-haberi/ Erişim Tarihi: 30 Mayıs 2019

H Sözlük. (2016) http://www.hsozluk com/videogallery/kaba-dogum-ve-kaba-olum-hizlari/ Erişim Tarihi: 15 Mart 2020

Iş1khan, Vedat (2014). "Sosyal Politika Kavramının Analizi”, Sosyal Politika içinde, Ed. Vedat Işıkhan, Erzurum: Atatürk Üniversitesi Açıköğretim Fakültesi Yayını, s. 4-31.

İçağasıŏlu Çoban, Arzu ve Özbesler, Cengiz (2009). "Türkiye'de Aileye Yönelik Sosyal Politika ve Hizmetler", Sosyal Politika Çalışmaları Dergisi içinde 18 (18), 31-42. http://dergipark.org.tr/tr/pub/spcd/ issue/21099/227224 Erişim Tarihi: 25 Mayıs 2019

Karatay, Abdullah (2016). "Kamuda Dönüşüm ve Çocuk Koruma Politikasında Değişim Eğilimleri”, Dezavantajlı Gruplar ve Sosyal Politika içinde, Ed. Betül Altuntaş, Ankara: Nobel Yayınc1lık, s. 13-34.

Koyuncu, Ahmet (2013). Bir Sosyal Güvenlik Sistemi Olarak Aile, Sistematik Aile Sosyolojisi içinde, Ed. Mustafa Aydın, Konya: Çizgi Kitapevi s. 357-378.

Köse, Begüm (2018). “Geçmișten Günümüze Aile”, Değişen Toplumda Değişen Aile içinde, Ed. Nurşen Adak, Ankara: Siyasal Kitapevi, s. 15-38.

KSGM. (2008). Toplumsal Cinsiyet Eşitliği Ulusal Eylem Planı (2008-2013). T.C. Başbakanlık Kadının Statüsü Genel Müdürlüğü, https://kadininstatusu.aile.gov.tr/ulusal-eylem-planlari/toplumsal-cinsiyet-esitligi-ulusal-eylem-plani Erişim tarihi: 20 Nisan 2020.

Millar, Janne (2011). "Sosyal Politika ve Aile Politikası", Sosyal Politika (Kuramlar 
ve Uygulamalar) içinde, Ed. Pete Alcock, Margaret May ve Karen Rowlingson. Çev. Boran Ali Mercan, Ankara: Siyasal Kitapevi, s. 222-230.

Milli Gazete. (2019). https://www.milligazete.com.tr/haber/1781575/erken-yasta-evlilik-magdurlari-topyekun-cozum-istiyor Erişim Tarihi: 29 Mayıs 2019

Özaydın, Mehmet Merve (2018). "Sosyal Politikanın Tarihsel Gelişimi” Sosyal Politika içinde, Ed. Abdurrahman İlhan Oral ve Yener Şişman, Eskişehir: Anadolu Üniversitesi Yayınları s. 28-62.

Özbay, Ferhunde (2017). Dünden Bugüne Aile, Kent ve Nüfus. İstanbul: İletişim Yayınlar1.

Resmi Gazete (1998, 12 Temmuz). 23400 sayılı, Kadın Konukevlerinin Açılması ve İşletilmesi Hakkında Yönetmelik, http://www. resmigazete.gov.tr//arsiv/23400.pdf Erişim Tarihi: 15 Nisan 2020

Resmi Gazete (1965) 12038 say1lı, Ka Mülkiyeti Kanunu, 1. Madde, https://www. mevzuat.gov.tr/MevzuatMetin/1.5.634.pdf Erișim Tarihi: 15 Nisan 2020

Talas, Cahit (1992). Türkiye'nin Açıklamalı Sosyal Politika Tarihi, Ankara: Bilgi Yayınevi.

Taşçı, Faruk (2017). Türkiye'de Sosyal Politika ve Dönüşüm (Zihniyet, Aktörler, Uygulamalar), İstanbul: Seta Yayınları. https://setav.org/assets/uploads/2017/04/SosyalPolitika.pdf Erişim Tarihi: 20 Ocak 2020

Timurturkan, Meral (2018). "Aile Birliğinin Bozulması: Boşanma ve Yeniden Evlen- me", Değișen Toplumda Değişen Aile içinde, Ed. Nurşen Adak, Ankara: Siyasal Kitapevi s. 201-219..

Tokol, Aysen (2018). “Türkiye'de Sosyal Politika”, Sosyal Politika içinde, Ed. Aysen Tokol ve Yusuf Alper, Bursa: Dora Basım Yayin, s. 63-78.

Tunca, Tuğçe (2018). "Türkiye'de Değişen Aile ve Çocuğa Yüklenen Anlamlar” Değişen Toplumda Değişen Aile içinde, Ed. Nurşen Adak, Ankara: Siyasal Kitapevi, s. 163-176.

Türkiye İstatistik Kurumu (2021a) İstatistiklerle Aile, 2020, Say1: 37251 https://data. tuik.gov.tr/Bulten/Index?p=Istatistiklerle-Aile-2020-37251

Türkiye İstatistik Kurumu (2021b) Evlenme ve Boşanma İstatistikleri, 2020, Say1: 37211 https://data.tuik.gov.tr/Bulten/ Index? $\mathrm{p}=$ Evlenme-ve-Bosanma-Istatistikleri-2020-37211

Türkiye İstatistik Kurumu (2021c). Dünya Nüfus Günü, 2021, Say1: 37250 https:// data.tuik.gov.tr/Bulten/Index?p=Dunya-Nufus-Gunu-2021-37250

Ulutaş, Ejder ve Özpınar Ahmet (2013). Toplumumuzun Aile Yapısı, Sistematik Aile Sosyolojisi içinde, Ed. Mustafa Aydın, Konya: Çizgi Kitapevi, s. 379-398. 


\section{Mekân ve Yașlılık}

İstanbul'un Farklı Bölgelerinde Yaşlılık ve Mekânsal

Pratikler

Beyza İSEN ${ }^{1}$

\section{Space and Elderliness}

Elderliness and Spatial Practices in Different

\section{Parts of Istanbul}

Beyza İSEN ${ }^{1}$

\section{Özet}

Sosyolojinin gündemine aldığı güncel meseleler arasında, yaşlılık konusu önemli bir araştırma problemi olarak karşımıza çıkmaya başlamıştır. Değişen Türkiye şartları çerçevesinde içinde bulunduğumuz dönemde "yaşlılık" meselesi farklı bir konum kazanmıstır. Toplumsal konular ele alınırken hali hazırda yaşlanan nüfusa sahip bir ülke konumuna geçişimizin önemi, son birkaç yıldır fark edilmekle birlikte, bu yeni oluşuma bağlı değişim ve dönüşümler başlanmıştır. Bu çalışma, yaşlılık meselesini konu edinerek, bireyin mekândan bağımsız düsünülemeyeceğini ön planda tutarak, yaşlıların mekân ile ilişkisine odaklanmaktadır. Kentte yaşayan yaşlıların, mekân ile ilgili memnuniyetlerinin nasıl olduğu, kendilerini yaşadıkları yere ait hissedip hissetmedikleri, mekânsal değișime tepkileri, mekânın onlara hangi imkânları sağladığı, mekânın onlar için bütünleştirici mi yoksa ayrıştırıcı bir tavır mı sergilediği gibi sorular, bu araştırma için temel soruları oluşturmaktadır.

Bu çalışma kapsamında araştırma sorularının içeriğini yaşlıların mekân algıları, aidiyetleri ve beklentilerine ilişkin görüşleri Henri Lefebvre'in mekân kavramına yaklaşımı perspektifinde ele alınmıştır. Araştırma çerçevesinde, yaşlı bireylerin mekânsal pratiklerinin okunmasına yönelik, farklı habituslarda yaşayan 65 yas ve üzeri kişilerle görüşme sağlanmış, yaşlı bireylerin mekânsal ilişkileri analizi yapılmış ve yaşlıların mekâna ilişkin paylaşımları ön plana çıkarılmıştır. Bu bağlamda İstanbul ilinde iki farklı semt örneği ele alınarak, mekânsal değișim, mekânın üretimi, mekân algısı ve yaşlı bireylerin mekâna yönelik ilişkilerinin değerlendirmesine yönelik bir çalışma sunulmuştur. Çalışma kapsamında Kadıköy ve Bağcılar ilçeleri seçilerek, 65 yaş ve üzeri bireylerden oluşan örneklem seçimi ile Kadıköy'de ve Bağcılar'da ikamet eden on kişi ile mülakat yapılmıştır.

\section{Anahtar Kelimeler}

Henri Lefebvre • Mekân • Mekân Alg1sı • Mekânın Üretimi • Yaşl1lık

1 İstanbul Ticaret Üniversitesi, Sosyal Bilimler Enstitüsü, Uygulamalı Sosyoloji Yüksek Lisans Bölümü, Yüksek Lisans,beyzaagul@gmail.com, ORCID: 0000-0002-6885-9693
Başvuru: 10 Ağustos 2021
Kabul: 30 Aralı 2021
k Revizyon: 6 Eylül 2021
OnlineFirst: 31 Ocak 2022
Copyright $\odot 2021$ İnsan ve Medeniyet Hareketi
http://toplumsaldegisim.com/ $20224(1) 28-55$

Abstract

Elderliness has been a matter of research, among the other current issues subject to the agenda of sociology. The subject of "elderliness" has started to be addressed in a different aspect in this period within the framework of the changing circumstances of Türkiye. Regarding social issues, the importance of the transition to a country with an aging population has been addressed in the last couple of months. On the other hand, changes, and transformations have started to appear along with this newly emerging formation. The present study discusses the matter of elderliness and focuses on the relationship between the elderly and space by considering that the individual cannot be thought of independently of space. Questions including to what extent are the elderly living in urban content with the space, do they feel belong in the place where they live, how do they react to changing location, what types of opportunities does space provide them, does space have a holistic or separatist attitude toward the elderly form the basis of this study.

Within the scope of this research, the content of research questions, including the opinions of the elderly on their spatial perception, sense of belonging, and expectations, was discussed with reference to the perspective of Henri Lefebvre's approach to the concept of space. Within the framework of the present study, people aged 65 and over who have been living in different habitats were interviewed to assess the spatial practices of the elderly. Their spatial relations were analyzed and those sharing practices related to the space were particularly stressed. In this sense, two different district examples were addressed and a study on the evaluation of spatial change, production of space, spatial perception, as well as the elderly's relations with space was provided. For the present study, the districts of Kadikoy and Bagcilar and a sample group consisting of individuals aged 65 and over were selected, and ten individuals who are residents of the districts of Kadikoy and Bagcilar were interviewed.

Keywords

Henri Lefebvre • Space • Spatial Perception • Production of Space • Elderliness 1 Istanbul Ticaret University, Institute of Social Sciences, Department of Applied Sociology, M.Sc., beyzaagul@gmail.com, ORCID: 0000-0002-6885-9693 


\section{Giriș ve Araştırma Probleminin}

Tanımı

Modernleşme başta olmak üzere toplumsal devinime sebep olan değişim süreçlerine bağlı olarak meydana gelen varyasyonların en önemli alanlarından biri kent mekânlarıdır. Kentlerde meydana gelen bu değişimin pek çok etki alanları da mekânlar üzerinden, bilhassa mekân-insan ilişkisi bağlamında okunabilmektedir. Toplumsa değişmeyi açıklarken temel aldığımız, Modernleşme, Sanayileşme, Kapitalizm ve kentleşme süreçleri mekâna yen bir boyut kazandırmıştır. Gecekondulaşma, apartmanlaşma ve uydu evlere varan konut biçimdeki farklılaşmalar; kentsel dönüşümler, nüfus artışı vb nitelikler, bireyler için yeni yerleşim yerleri oluşturmuştur. Yeni yaşam alanları beraberinde gündelik pratiklerdeki farklılasmaları da meydana getirmiştir. Bu araştırma için temel alınan kısım, yaşlı bireyler için yeni mekânlar oluşturulmuş olmasıdır. Bu tezin çalışma alanını İstanbul gibi kozmopolit bi kentte, farklılıkların gözlemlenebilme imkânının mevcudiyeti göz önünde bulundurularak, farklı iki yakasından ilçeler tercih edilmiştir. Bu bağlamda, nitelikli karşılaştırmalar ve ilişkise açıklamalara ulassılmasına yönelik, İstanbul'un en eski yerleşim yerlerinden biri olan Kadıköy ilçesi ve en kalabalık nüfuslu yerlesim alanlarından biri olan Bağcılar tercih edilmiştir.

Son 15 yılda inşaat sektöründe meydana gelen sıçramalar, yeni yerleşim alanları oluşturulma hızı, değişen konut ihtiyacı, toplu konut inșası, artan nüfus, göçler... vb. durumlar mekânsal değişimi meydana getirmiştir. Bu değişimin en çok etkilenen gruplarından biri de yaşlılardır. Nitekim, yaşlı bireylerin zamanlarının birçoğunu emeklilik, sağlık problemleri, karmaşadan kaçış gibi sebeplerle evde geçiriyor olmaları, yaşadıkları mekân ile kurulan ilişkinin önemini artırmaktadır. Tezin ana araştırma sorusunu, yaşlılık döneminde mekân ile nasıl bir ilisski kurulduğu, mekâna ilişkin beklentiler ve yaşlı bireylerin gündelik pratiklerinin mekâna bağlı olarak nasıl şekillendiği meselesi oluşturmaktadır. Yaşlı bireylerin yaşadıkları çevrenin, yaşam biçimlerine nasıl sirayet ettiğinin ölçümlemesi, mekânsal algıları bağlamında açıklamaktadır. Alt araştırma sorularının içeriği ise şu şekildedir:

- Ülkemizde yaşlılık ve yaşlı nüfusundaki artış neyi ifade etmektedir?

- Kentsel mekânda meydana gelen değişim ve dönüşümlerin etkileri nasıldır?

- Yaşlı algisında mekân ne ifade etmektedir?

- Yaşlı bireylerin mekâna ilişskin beklentileri nelerdir?

- Mekân yaşlı bireyler için kısıtlayıcı mı yoksa özgürleştirici mi?

Araștırmanın temel hipotezi ise șu şekildedir: "Mekân ve mekânla kurulan ilişkiler, mekânsal değişimlere bağlı olarak, yaşlılık pratiklerini etkilemektedir."

Mekân, mimarisi, fiziksel özellikleri ve hisleriyle bir bütündür ve tüm yönleriyle değerlendirilmelidir. Mekân insanlar için hem bir barınma ihtiyacının merkezi hem de diğer insanlarla kurulan ilişkilere anlam veren yerdir. Mekânın varlığı ve nitelikleri, sosyal ilişkilere olanak sağlamakta ve beslemektedir. Yaşlılık döneminde mekân ile kurulan ilișkinin tanımlanması ve bu ilişkinin farklı biçimlerinin okunması, toplumsal alanın bi nebze dışında kalmış bir grubun tekra merkezine çekilmesine olanak sağlamaktadır. Yaşlı bireylerin sehir hakkından yeterince faydalanıp faydalanamıyor olması önemli bir problem niteliği göstermektedir. Nitekim herkesin sehir hakkından faydalanabiliyor olması bireysel bi anlamda doyum sağladığı gibi toplumsal harmoniye de hizmet etmektedir.

\section{Yaşlılık ve İlgili Kavramlara Bakıs}

\section{Yașlılık Kavramı}

Literatürde yaşlılık kavramını açıklamaya yönelik çabalar, genellikle kronolojik tanımlamayla bașlayarak, biyolojik, sosyolojik ve psikolojik tanımların temelinde bir bütün olarak ele alınmasının gerekliliği üzerinde durmaktadır. Yaşlılığı çoğunlukla bireyin yașına bağlı olarak tanımlama eğilimi yaygındır. Dünya Sağlık Örgütü (WHO, 1998) yaşlılığ 1 kronolojik olarak el almıs ve yaşlılığın başlangıcını 65 ya olarak belirtmiștir. Ama tabi bu tanımlama dönemlere, kültüre ve sosyal ortamlara göre değișebilmektedir. OECD (1992) yaşlı nüfusu “davranış ve ihtiyaçları değișen, 65 yaş üzerindeki insanlardan olusan heterojen bir grup" olarak ele almaktadır (Kalayc1, 2011, s. 4)

Bütüncül bir yaklaşımla ele aldığımı da yaşl1lık kavramı, 65 yas üzeri bireyler ilgilendiren bir sınırlılığa sahip değildir. Toplumun her kesimini kapsayan, her bireyin tecrübe etmesi kaçınılmaz olan bir durumdan söz edilmektedir 'Yaşlı'nın anlaşılabiliyor, önemseniyor ve yasatılabiliyor olması, toplumsal bütünlüğün sağlanabiliyor olması demektir
Yaşlılık kavramının tanımlanmasının dönemlere, kültüre ve bireysel yetişkinliğe bağlı değișebildiği, psikolojik ve sosyal alanlarda da yorumlandığ 1 gerçeği, yaşlılığın toplumsal bir olgu olarak ele alınmasının önemini göstermektedir (Kalaycı, 2011, s. 4). Bu bağlamda 'yaşlı'nın topluma ve yaşlılığa ilişkin algısının sosyolojik perspektiften ele alınması, yaşlılık kavramının, bireyin sosyalleşme alanı olan mekân ile ilişkisi çerçevesinde değerlendirilmesi, yaşlılığa ilişkin göz ardı edilen durumların farkındalığının kazanılmasına olanak sağlamaktadır. $\mathrm{Bu}$ araştırmada ülkemizde sınırlı sayıda araştırmalara konu olan yaşlılığg, yaşlılığgn ve mekânın kentlileșme ve modernleşme sürecinde uğradığı değişimi temel alarak yaşlılık ve mekân ilişkisini ortaya koymaya çalışmaktadır.

Yaşlılık konusu, tüm insanlığı ilgilendiren bir konu olmasının yanı sıra, yaşlı nüfus ve yaşlanmakta olan nüfus özelliği gösteren toplumlar için başlıca önemlilik arz etmektedir. Ülkemizin genç nüfus özelliği gösterdiği düsüncesi, zihinlerde bir yanılsama olarak karşımıza çıkmaktadır. Nitekim Türkiye günümüzde yaşlanan nüfus özelliği gösteren bir ülke konumunda olmakla birlikte yakın zamanda yaşlı nüfus nitelendirmesine uygun bir yapıya bürünecektir. Yaşlılık meselesi, bireysel olarak biyolojik yaşlanmanın da ötesinde bir anlam ifade etmektedir. Yaşlılık olgusunun bu araştırma içeriğinde problematize edilmesinin bașlıca sebebi, yașlılığın göz ardı edilen anlamlarına ve bağlamlarına yönelik bir farkındalık olusturulmasının sağlanmasıdır. Bununla birlikte toplumlar ve bireyler açısından belli kalıp yargılara bağlı olarak yerlesen negatif yaşlılık algısına alternatif çerçeve sunulması ve yaşlılığın 
toplumsal alanda yapılacak okumalarda hatırı sayılır bir öneminin olduğunu ön plana çıkarmaktır.

\section{Nüfusun Yaşlanması}

Yaşlılık araştırmalarıyla birlikte, son yüzyılda ön plana çıkan kavramlardan biri de nüfusun yaşlanmasıdır. Teknoloji çağının getirdiği imkânlar ve sağlık alanında meydana gelen gelişmelerle birlikte insanlar daha uzun yıllar yaşay abilmekte, ölüm oranları ve doğum oranları azalmakta, dolayısıyla yaşlı nüfus oranı artmaktadır. Gelişmiş ülkelerd duymaya alıskıı olduğumuz bu sürec, günümüzde gelişmekte olan ülkeler için de gecerli olmaya baslamıstır (Mura ŞENTÜRK, Harun CEYLAN, 2015, s. 13). Türkiye'de de yaşlı nüfus oranın son be yılda \%22,5 (TUIK, 2020) oranında artı gösterdiği gerçeği, yaşlılık, yaşlı nüfus ve yaşlılığa ilişkin konuları gündeme almanın gerekliliğini göstermektedir. Yaşlı nüfus olarak kabul edilen 65 ve üzeri nüfus, son bes yılda \%22,5 artarak 2020 yılında 7 milyon 953 bin 555 kiş olmuştur. Yaşlı nüfusun toplam nüfus içindeki oranı ise, 2020 yılında \%9,5' yükselmiştir. Nüfus projeksiyonlarına göre yaslı nüfus oranının 2040 yılında \%16,3'ları yakalaması ön görülmektedi (TUIKK, 2021). Yaşlı nüfus oranının rakamsal ifadesi ülkemizdeki değişimin ne bir göstergesidir. Bu sebeple sosyolojik bakış açısıyla yaşlılık kavramını ele alma meselesi gündemin önemli bir konusu haline gelmektedir.

Yaşıt olma durumu, çağdaşlık (ayn çă̆da yașayan, çă̆cıl) gibi sınıflamalar insanların birbiriyle kurduğu ilişkilerde belirleyici bir unsur olabilmektedir. Bu sebeple yaşıtlarınla yakın olma, habitatında vakit geçirme isteği her yaş grubu için tercih edilebilir niteliktedir. Yaşlılar için de bu durum çevresel sartlarla birlikte değerlendirilmeli; aile, komşu, arkadas çevresi ve mekânla kurulan ilişkiler bir bütün olarak ele alınmalıdır. Yapılan araştırmalar da bunu destekler nitelik göstermektedir. Yaşlı bakımevimdeki yaşlılarla yapılan çalışmalarda, orada yaşamakta olan bireylerde, alışık olduğu gündelik yaşamdan el çekmek zorunda kalmanın olumsuz etkileri gözlemlenmektedir (KÜNTAY, 2014). Yine kentsel dönüşüm ve yaşlılık bağlamında yapılan araştırmalar, yaşlı bireyin yeni bir ev sahibi olmak yerine, sahip olduğu ev ve komşuluk ilişkilerini devam ettirmeyi tercih etmesi yönündeki düşüncenin baskın olduğunu göstermektedir (Cem ERGUN, Ayşe DERICIOĞULLARI ERGUN, 2010). Bu bağlamda yerinde yaşlanma kavramının önemine dikkat çekebiliriz. Yerinde yaşlanma kavramı "yaşlıların bildikleri bir ortamda yasama arzusunu”, ifade eden bir yaklaşımdır. Bireyin yerinde güvenle yaşlanması, yaşlı bireyin, ailenin ve toplumun bütünsel faydasına işaret etmektedir. Yerinde yaşlanma, kişinin hem fiziksel hem psikolojik yönden ihtiyaçlarının karșlanmasını sağlayarak yaşam kalitesinin artmasını sağlamaktadır (Velittin KALINKARA, Fatma ARPACI, 2013, s. 58). Yasliların evini ve evinin çeperindeki alanı ifade eden bu kavram, yașamımızı inșa ettiğimiz kişisel ve sosyal dünyamızın, tüm yaşam sürecimize tanıklık etmesi ihtiyacının bir göstergesi konumundadır.

\section{Yaşçılık}

Yaslılık konusu ele alınırken bahsi geçen önemli kavramlardan biri de 'yaşçılık'(ageism) kavramıdır. Bu çalışma kapsamında derinlemesine bir yas ayrımcılığı konusu işlenmemekle birlik- te, ayrimciliğ besleyen ön yargilı tutumların, yaşlı bireylerin hayatını son derece zorlaştıran bir durum olduğunun alt çizilmesi gerekmektedir. Yasçılık, ırkçılık ve cinsiyetçilik gibi diğer ayrımcı yaklaşımlar kadar toplumsal ilişkileri etkilemektedir. Yașlı bireyler sadece yașları yüzünden iş yaşamında, insanlarla olan ilişkilerinde veya sosyal hizmet alırken ayrımc davranışlarla karşılaşmaktadır. Yaşçılık zamanla ideoloji haline gelerek, ileri ya gruplarına karsı tutum ve davranıslar etkileyen bir unsur haline gelmektedi (Kayacan, 2017, s. 17). Yaşa bağlı ayrımc tutumlar yaşlıların iş yaşamını sosya yaşamını olumsuz etkilemekte, yaşlı istismarına sebep olmaktadır. Yaşlı istismarı, yaşlı bireyin sağlık veya iyilik halini tehdit eden veya zarar veren herhangi bi davranıștır. İstismar bedensel, psikolojik veya ekonomik olabilir, aynı zamanda ihmale de dönüsebilmektedir (Akdemir, Görgülü, \& Çınar, 2008, s. 69).

Bir insanın net bir bicimde ne zaman yaşlı olarak tanımlanabileceğinin genegeçer bir kabulü yoktur. Dünya Sağlı Örgütü ve benzeri kuruluşların, 65 ya üstüne işaret eden yaşlılık çalıșmaları, sosyal politikaların üretimine yönelik bir alan belirlenmesi konusunda ihtiyac karsılamaktadır. Ancak sosyolojik perspektifle bakıldığında toplumların, ülkelerin, kültürlerin ve bireylerin objektif bir yaşl tanımlamasına sahip olması beklenmemektedir. Her bireyin yaşlılığa dair tanımı, beklentileri, yargıları farklılık göstermektedir. Nitekim araştırmalar da bu açılamaları destekler niteliktedir. Örneğin 2010 yılında yayınlanan Avrupa Sosyal Anketi'n göre "Sizce bir insan kaç yaşından sonra yaşlı sayılır?" sorusuna Türkiye'de 55 yaş, Portekiz'de 66 yas, Yunanistan'da 68 yas ifadelerine yer verilmiştir (ÇAYIR, 2018, s. 82)

\section{Türkiye'de Yaslılık}

Türkiye'de var olan genç nüfus dinamiği, yaşlı nüfus endișesinin göz ardı edilmesine sebep olabilmektedir, ancak Türkiye dünyanın en hızlı yaşlanan ülkeleri arasında yer almaktadır. Birleşmiş Milletler, 65 yaş üstü nüfusun yüzde yedilere ulaștığ 1 ülkeleri yaşlanan nüfus kategorisinde tanımlamaktadır. Tüm bu istatistikler Türkiye'nin mevcut durumuna ișaret etmektedir (Özbay, Dünden Bugüne Aile, Kent ve Nüfus, 2015: s. 322). Yaşlı nüfus oranının artış göstermesi, yaşlı nüfus sorununu da beraberinde getirmektedir, zira mevcut düzenin, yaşlı nüfusu toplum içine entegre edici bir nitelik taşımaması, yaşlılara karşı oluşan dışlayıcı algıyı beslemektedir. Nitekim modernitenin getirdiği çekirdek aile tipinin yaşlı ebeveyni 'yuva' dışında yalnız yaşamaya itmesi yetișkin çocuk ve yaşlı ebeveyn ilişkilerinin zayıflamasına sebep olmakta, bu süreçte ilişkilerin zayıflaması ve hatta kopması, ön yargıların oluşmasını da pekiştiren bir nitelik göstermektedir. Bunun sonucunda yasslı birey hem aile içi konumunda hem de toplumsal alanda dışlayıcı bir tavra maruz bırakılmaktadır (Kalayc1, 2011: s. 26).

Türkiye'de yaşlıların durumu, henüz yaşlılık çalışmaları dahilinde nispeten kedine dar bir alanda yer bulsa da yaşlılık meselesini ele alan sosyal hizmete yönelik çalışmalar yapılmakta, yaşlılık raporları yayınlanmakta ve yaşlılık atölyeleri gerçekleştirilmektedir. 2007'de Birinci Türkiye Yaşlılık Raporu'nun yayınlanması bu gelişmelere bir örnek teşkil etmektedir. Ancak bu çalışmalar yaşlılık politikalarını sosyal politikaların bir alanı olarak ele almak üzerine temellendirilmekte, yaşlılara karşı ayrımcı 
tutumlara ve toplumsal sonuçlarına yeterince değinilmemektedir (Tufan, 2007: s. 32). İstanbul Üniversitesi Sosyoloji Bölümünde Sosyoloji Araştırma Merkezi bünyesinde Yaşlılık Atölyeleri düzenlenerek, yaşlılıkla ilgili çalışan akademisyenler, kamu-özel sektör çalışanları, STK'lar, ilgili öğrenciler bir araya getirilerek, yaşlılık durumuna dair düşünse bir zemin sunulmakta, var olan sorunla ortaya konularak çözümsel bir yaklaşım benimsenmektedir.

Toplulukçu kültürlerde yaşlıya sayg göstermek, genel bir anlayış olarak günlük ritüellerin içinde yer alır. Bireyciliğin ağır bastığı Batı Kültürlerinde ise yaşlıya saygı göstermek 'şart' koşulmaz. Ancak bireyin kişisel özellikleri sayesinde sayg1 kazanması mümkündür (Kalaycı, 2011:24). Yaşlılığın toplumsal yapılardan bağımsız düşünülmesi mümkün olmamaktadır. Türkiye toplulukçuluk-bireycilik kültürleri arasında yer almaktadır, bu nedenle bir yandan yasliya saygı göstermenin önemi vurgulanırken bir yandan geçmişteki kadar yaygın bir sayg anlayışı olmadığı gözlemlenebilmektedir. Nitekim son yıllarda da çeşitli birçok etkiye bağlı olarak yaşlıları dışlayıc davranışlara sıklıkla rastlanmaktadır. Yapılan araştırmalarda yaşlıların yaşlandıktan sonra en çok zorluk çektiği konular arasında insanların saygısız davranışları da yer almaktadır (APK Daire Başkanlığı Araştırma Müdürlüğü, 2004 s. 28). Yine 65 yaş üzeri nüfus ile yapılan bir araştırma da katılımcıların yüzde ellisi toplumumuzda yaştan kaynaklanan bir ayrımcılığın varlığını kabul ettiğin söylemektedir. (Marmara Üniversites Bilimsel Araştırma Projeleri Komisyon Başkanlığ1, 2008: s. 94)

\section{Mekân Kavramı Üzerine}

Mekânlar toplumsal devinimde, her alanda meydana gelen değişim ve dönüşümlerin etkisiyle, zaman içerisinde farklı tanımlamalara ve ihtiyaçlara göre varlık göstermiştir. İnsanlığın varlığ 1 için gerekli olan üretim ve bu üretim biçimleri mekânın değişiminde en etkili unsurlardan biri olmuştur (Şentürk Ü. , 2014, s. 85). Tüm dünya için toplumsal değişimin temeli olarak ele aldığımız modernite öncesi insanlar, mekânları ihtiyaçları dahilinde üretmiș ve kullanmışlardır. Mekân bu dönemde bireylerin kendi düzenlemelerine tabii, doğayla uyum içerisinde, ayrıştırmadan ve çevre kirliliğinden uzak, geleneksel toplum yapısına bağlı uzun yıllar varlık göstermiştir. İlk şehirlerin kurulmasından endüstri toplumuna kadar devam eden bu dönem insanların doğayla ve mekânla gerçek bir ilişki kurabildiği, kendi ihtiyaçlarına göre oluşturduğu için, benimseyebildiği mekânların varlığına imkân tanımıștır. Endüstri toplumunun gelișimi ile, mekânlar da rasyonelleşme akımın etkilerine maruz kalmış ve bununla birlikte yaşam alanlarının, mekânların parçalanması söz konusu olmuştur. Kentsel mekânların yeni düzenler üzerine kurulmasıyla birlikte, kullanım değeri üzerine tanımlanmaları yerine değişim değerine geçilmiştir. Mekânların kullanım değerine uygun olması, bireylerin gündelik ihtiyaçlarını sağlamaya yönelik, bireysel, sosyal tüm faaliyetlerini tek mekânda topladığı, zevklerini tatmin edecek nitelikteki mekânlar özelliği göstermektedir. Günlük kullanıma yetkin, toplumsal faydaya yönelik üretilen mekânlardan, mimari yetkinlikleri sağlamaya yönelik, betonarme mekânlara geçilmiştir.
Kapitalizmin insan ilişkilerini azaltıp, bireyleri yalnızlaştırma yönündeki etkileri bu çerçevede mekân üzerine et kisinden de okunabilmektedir. Oysa mekânın anlamı birleștirici niteliğiyle anlamlı olmaktadır. Mekân başkalarıyla ilişki içinde olmamızı sağlamaktadır, bu bağlamda insan ilişkilerine, yaşamımıza anlam veren yer özelliği göstermektedir. Mekân bu bağlamda sosyal ilişkileri beslerken aynı zamanda sosyal ilişkilerden de beslenerek var olmaktadır.

Endüstrileşme sonrası, mekânın toplumdaki işlevinin nasıl değiştiğ konusu üzerinde duracak olursak David Harvey'in bu konudaki açıklamaları önemlilik arz etmektedir. Harvey, mekânın toplumdaki işlevinin değișimini zaman ve mekân sıkıșması kavramıyla açıklamaktadır. Televizyon, sosyal medya ya da haberleşme kanallar vasıtasıyla dünyanın farklı mekânlarından gelen görüntülerin hızla akışının sağlanması, değişik mekânları üst üste getirmektedir. Böylece mekânların temsilleri gösterilmekte, geçici kullanıma hizmet etmektedir, bu bağlamda gerçek yaşamın yerini, gerçeğin temsili olan benzetimler almaktadır. İletissim araçlarının is birliği ve düzeni üzerine kurulu yeni bilgi toplumunun mekân da insan ilişkilerini bu alanda sınırlandırmaktadır. Bireyler ilișkilerin iletişim ağına bağlılıkları ve kullanımları düzeyinde yürütebildikleri için, bu ağın dışında kalmak dışlanmakla eş an lamlı olmaktadır. Nitekim yaşlılar için de bu ağdan yararlanamama ve dahil olamama durumu eşitsizliğe sebep olmaktadır (TEKELİ, 2011: s. 121).

Tüm mekânsal yapılar merkezinde bir öznenin varlığ 1 ile kendini göstermektedir. İnsan mekânın öznesi olarak, kendisi ve gelistirdiği sosyal iliskileriyle birlikte mekânı oluşturmaktadır (USTA, 2020: s. 26). Mekân ve insan ilişkisinin bağ1 mekânların değişken bir yapıya sahip olmasını sağlamıştır. Fakat bu değişkenlik doğal bir süreçten ibaret olmamakta, yapay kentler üretilmektedir. Harvey ekseninde, mekân dediğimiz olgunun, toplumsal olarak belli kissiler için üretildiğini ve insanlar tarafindan üretilen bu sosyolojik sahanın, yine insanları etkileyen de bir yönünün olduğu ifade edilebilmektedir. Köksal Alver'in de deyişiyle:

"Belli bir inanç, değer ve kültür varlığ olan insanın eli bir yere değer ve o yer bir mekâna dönüşür. 0 yer, yer olmaktan çıkar ve adın bulur. Adı mahalle olur, sokak olur; ev, çarşı, hapishane, park, meydan olur" (ALVER, 2010: s. 118).

$\mathrm{Bu}$ bağlamda mekânlarda insanlara ait dokuların varlığından söz edebiliriz, bu dokular alanların, mekânların bağıdır ve aynı zamanda insanların birbiri ile ilişki içerisinde olmalarını sağlamaktadırlar.

Mekân ile ilgili mekân algısı olarak nitelendirebileceğimiz önemli olan ikinci bir kavramda vardır ki, mekânın varlığını özümsemekle ilişkilendirilmektedir. Mekân algısı, basit tanımıyla mekânın bilincine varmaktır. Mekânı algılarımız ile içselleştirir, davranışlarımız ile yönlendiririz. Bu sebeple mekâna ve kişisine bağlı olarak da mekânsal algı farklılaşmaktadır. Kişiler, mekânı barınma gereksinimi başta olmak üzere, ihtiyaçları ve beklentileri çerçevesinde kullanmaktadırlar. Bu ihtiyaçlar ve beklentiler karşılandığı düzeyde mekânın randımanı artacaktır (ÇİFTÇİ, 2019, s. 6). Her bireyin mekândan beklentileri farklı olmakta ve mekâna bağlı al- 
gıları da değișkenlik gösterebilmektedir. $\mathrm{Bu}$ alg1 ve değişkenlikler üzerinden, kişilerin mekânla ilişkileri, mekânın niteliğ okunabilmektedir, tüm bunların ken mekânına yansımalarının çalışması, mekân sorunsalının çözümlenmesi açısından önemlilik arz etmektedir.

David Harvey, kent ve mekân konularında Marksist alana önemli katkıla yapmıstır. Aynı zamanda kentsel mekân alanına da toplumsal yapı ve ilişkileri anlamaya yönelik açıklamalar getirmistir. Kapitalizmin devamlılığı için kentsel farklılaşmanın etkin bir rol üs tlendiğini, kentsel mekânın aynı zamanda çatışmanın mekânı olduğunun a tını çizmektedir. Harvey'e göre modern kentler, sermaye sahiplerinin kârların artırmaları yönünde kullanılmaktadır (Kurban ve Akman, 2019, s. 3267).

Harvey, kenti anlamanın hem toplumsal hem de coğrafi düsünceyi kapsayacak ve bundan hareket edecek bir kavramsal çerçeve ile mümkün olacağını ifade et mekte ve sosyolojik ve coğrafi yöntemlerin bu şekilde kaynaştırılması ile kentse sorunların üstesinden gelinebileceğin düşünmektedir. Kentin mekânsal biçim insan davranıslarının temel belirleyicis olarak görülmektedir (Solak, 2017, s. 32) Harvey, Lefebvre perspektifinde ilerleyerek, sermaye birikim süreçleri ve ken mekânı arasındaki ilişkileri ortaya koyan calısmalar yapmaktadır. Kentlesmenin sanayilesmeyi belirlemesi, bu sürecte mekânın yeniden yapılandırılması, kapitalizmin varlığını sürdürebilmek için, b mekân devingenliğinde baș rolü almas konusu bu çalışmaların genel niteliklerini çizen çerçevedir.

Heidegger, bir yerin oturanların özelliklerine göre inşa edildiğini, içinde bulunduğu fiziksel ve beşerî topografya ile sekillendiğini söylemektedir (Solak, 2017, s. 27). Mekânın insanlar için yaşanılan ya da iş yapılan yer olma özelliğinden öte bir anlam ifade ettiği konusu barizdir ki, mekânın dönüşümü sosyal iliskiler ve bireysel gündelik pratikler üzerinde de etkili olmaktadır.

Mekân ve insan için karşılıklı etkileşimin yoğun olduğu, iç içe geçmiş bir yapıdan söz edilebilmektedir. Mekânlar insanlar için beton yığını olmaktan öte bir anlam ifade etmektedir. Cünkü mekân insanı fiziksel, sosyal ve psikolojik yönlerden etkilemektedir. Toplumsal yaşamın bir parçası olarak bireyler bulundukları mekân ile bir bütünleşme içinde olmaktadırlar. Bu bütünleşme yasanılan yer ya da is yerinin bulunduğu alan olmasına bağlı değişiklik göstermekle birlikte kaçınılmaz bir ilişkidir. Bireyleri mekânından koparmak, insan vücudunun uzuvlarından birini koparma etkisi ile eș değerdir. Mekân iliski kurduğumuz bir alan olarak hayatımızdaki en önemli parçalardan birini oluşturmaktadır. Bununla birlikte mekân ve mekânda kurulan ilișkiler şehrin devamlılığını sağlamaktadır. Mekânlar insanın evi gibidir. Mekân insanlar tarafindan benimsenen sahiplenen bir alan olarak karşımıza çıkmaktadır, bu nedenle mekân ve insan birlikte düsünülmesi gereken iki kavramdır, biri olmadan diğeri anlamsız kalmaktadır. Mekândaki her parça oradaki iliski ağını olușturmaktadır, bunlardan birinin kaldırılması dahi sosyal iliskilerin kaybedilmesine sebep olmakta ve gündelik pratiklerin alışıldık düzenini bozmaktadır.

Mekânın devingenliğine bağlı olarak, anayilesme sonrası mekânların yeniden yapılandırılması söz konusu olmuştur.
Büyük şirketlerin, işletmelerin çoğalması, insaat sirketlerinin girisimleri, toplumsal yapıları değiştirerek, toplumsal dönüşümü gerçekleștirmiștir. Kapitalizme bağlı gerçekleşen bu eylemler insanların birbirleriyle ilişkilerin sinırlamakta ve yalnızlasmasına sebe olmaktadır. Oysa mekân başkalarıy la ilişki içinde olmamızı sağlayan sosyalleştiğimiz yer anlamını taşımaktadır. Yaşamımıza anlam veren yer olan me kân, bu anlamiyla sosyal iliskileri beslemekte, sosyal iliskiler de mekânı beslemektedir. Modern toplumlarda, değişen mekân olgusu ile, parçalanmıs mekânsa yapılar kendini göstermektedir ve bu durum insanları şehrin dokusundan kopuk, yasadığı alanla sınırlı iliskiler kurm şartlarına bağlı kılmaktadır.

Her bireyin mekânla öznel bağları olması ile, özellikle çocuklar ve yaslılar içi evler asıl ortamdır, bu sebeple kiși sosya fiziksel refahı için yerel çevreye bağıml konumdadır. Kentsel mekânda güvenlik hissi, arkadaşlık, sosyalleşme ihtiyac vs. gibi konuların tatmini sebebiyle konut ortamı oldukça önemlidir (Kurban, Akman, 2019, s. 3270). Konut ortamının bu önemi yaşlı bireylerin mekânla kurdukları iliskilerin cerçevesini cizmektedir. Yaşlı ve mekân ilişkisi bu çerçevede okunabilmekte, mekân beklentilerin alternatif sunulabilmesine imkân tanmaktadır. Kişilerin, bilhassa bu çalıs ma kapsamında yaşlı kișilerin var olan kent hakkından yararlanmasına imkân tanınması gerekmektedir. Herkesin şehir hakkından yararlanması toplumsa harmoniyi sağlamaktadır.

1949 yılında insan haklarına sayg ekseninde kurulan Avrupa Konseyi'nin kabul ettiği "Avrupa Kentsel Sartı” kentli haklarının, bilhassa kentteki insanın hakları temelli bir içeriğe sahip olmasıyla, kentli haklarının somut bir ifadesi özelliği göstermektedir. Şart içinde yer alan haklara bakıldığında herkesi kucaklayan iyileştirici nitelikler savunulmaktadır ve tüm haklar yaşlı bireyleri de elbet kapsamaktadır, fakat bununla birlikte yer alan bir maddede yaş kavramına ayrıca yer verilmesi araştırma kapsamında altının çizilmesi gerekliliğini sağlamaktadır. İlhan Tekeli, Kent, Kentli Hakları, Kentlesme ve Kentsel Dönüşüm isimli kitabında bu konuya değinmiş, bahsi geçen maddeye yer vermistir: "Kentte yaşayanların yas yetenek ya da gelir ayrımı olmadan yeterli çeşitlilikte spor yapma ve boş zamanları değerlendirme olanaklarından yararlanabilme hakk1” (Tekeli, 2011, s. 189).

\section{Mekânın Bedenselleşmes}

Mekânlar, var oluşu itibariyle bireyle iç içe bir konum sergilemesi, belli bir karakter kazanmasının da kaçınılmaz sonucunu doğurmuştur. Herhangi bir sehri ele aldığımızda, o șehre ait ilçeleri, mahalleleri düsündüğümüzde her bir alan için zihinlerde ayırt edici bir nitelik söz konusu olmaktadır. Bir mekânın kendine özgü yapısı, onu diğer mekânlardan ayıran temel davranış biçimleri, toplumsal algılar, davranıslar ve kültürel yapılar ile var olmakta, dolayısıyla mekâna yansıyan tüm bu uygulamalar mekânı bedenselleştirmektedir. Bu çeçevede mekânın anlatımında ‘beden'e değinmemek noksan bir izaha sebep olmaktadır. Bourdieu'nun sosyal statü ve sınıf konumunun günlük yaşamda nasıl somutlaștığını anlamak için kullandığı habitus kavramı da bedenin kültürel özelliklerini ve sosyal yapıyı üreten bir niteliğe sahip olduğunu ifade etmektedir (Low, 2003, s. 12). 
Mekânsal alanın beden ile ilişkisine ait bir başka bakış açısı sunan 'habitus' kavramı, kişilerin yaşadıkları mekân içerisinde bedenlerine işlenen tüm bigilerin varlığına açıklık getirmektedir. Bourdieu'ya göre beden, habitusu şekillendiren toplumsal normların işlendiğ yegâne yer konumundadır. Bedene nakşedilen gelenekler kişinin gündelik pratiklerinde, eylemlerinde, tüm tercihlerinde karşımıza çıkmaktadır. Bu bağlamda beden kültürel kodların, bi anlamıyla da bulunduğu mekânın hem kayıt yeri hem de bu kodları üreten bir etkendir (Arpac1, 2020, s. 246).

Bedenlerimiz, dünya ile iliski içinde olduğumuz, zihnimizin fiziğimize yansıdı̆̆ı bir alandır. İnsan bedeniyle mekânda var olur, mekânı bedeniyle deneyimler ve algilayan beden ile ait olduğu çevre birbirinden ayrılamaz konumdadır, mekân ve beden birbirin besleyen var eden iki oluşumdur. Beden kendini mekânın içinde hissetmektedir ve mekân bedenin tecessüm etmesi şeklinde uzantısı haline gelmektedir. Beden içinde bulunduğu mekânı algılayarak, kendi içinde yeniden oluşturarak ve onu çevreye yansitarak meydana getirmektedir (Üstün, 2015, s. 7). Beden üzerin fenomenolojik yaklaşım çalışmaların sahibi Merleau-Ponty, 'beden mekân için rahimdir' ve 'bedenim olmasaydı benin için mekân da olmazdı' sözleri mekânın bedenin her hareketi ve algıları ile va olduğunu ve yeniden yapılandırıldığ açıklamasını anlamlandırmaktadır. Beden ve mekân arasındaki bu devingen ilişki için birbirini var eden, birbirinden etkilenen bir ilişki söz konusu olmaktadır (Özbek, 2018, s. 134).

İnsan ve mekân ilișkisi mevzu bahi olduğunda, bu ilişkinin karşılıklı et- kileşiminden doğan sonuçlarından biri de kișinin içinde bulunduğu mekânın dokularının bedenine işlemiş olmasıdır. Mekânlar adreste tarif edilen isimlerden, tabela ibarelerinden öte anlamlar taşımaktadır. Mekânın doğal oluşum süreci, insan üretimiyle iliskili olup, benimsemesi hiç de zor olmayan, kendi bedeninin yasamasina uygun yaratılan ve düzenlenen bir özelliğe sahiptir. İnsanların hareketleri, mekânı anlamak, satır aralarını okuyabilmek açısından kritik bir öneme sahiptir (LOW, 2014, s. 41). Bedensel hareketler farklı türde mekânlar üretebilmektedir. Bedensel hareketlerimiz ve algılarımızın cisimleștiği alan olarak bedenselleşmiş mekân karşımıza çıkmakta ve bu araştırma için, bireylerin yaşlı algıları ve bununla ilgili uygulamalar, tutumlar mekâna nasıl yansıyor, bu vasıtayla nasıl mekânın bedenselleşmesi söz konusu oluyor sorularına cevaplar aranacaktır.

\section{Yaşlılık ve Mekân}

Toplumsal alanda taşıdığımız ortak paydalar bizleri istemsizce belirli gruplara dahil etmektedir. Kadınlar, gençler ve çocukların ayrışmaları gibi yaşı bireyler de geç yetişkinler grubuna dahil olarak ortak değerleri paylaşmaktadır. Bu şekilde bakıldığında kolektif kimlik, zihinsel süreçlerle ilişkili olarak herhangi bir grubun üyelerinde kendilerini ortak geçmișe bağlı olarak tanımlamaları sonucu getirmektedir (Morley \& Robins, 2011, s. 74). Algılar içinde bulunduğun mekânın ve ait olduğun grubun niteliklerine bağlı olarak oluşmakta ve yine bir süreç olarak oluşumunu devam ettirmektedir. Yaşlı bireylerin içinde bulun- duğu mekânın kimliğini taşıyor olmas bu sürecin en belirgin özelliğidir. Mekânın bireyden ayrı düşünülmesinin imkânı olmadığı gibi bireyin de mekândan bağımsızlı̆̆ı söz konusu olmamaktadır. Yaşlı bireylerin, bulundukları mekânla geçirdikleri sürenin her toplumsal gruba göre fazla olması, onlarla ilgili çalısmalara mekânsal boyutun dahil edilmesinin önemini göstermektedir. Ylllarca belirli bir mekânda yaşamış erişkin birey herhangi bir kişiye göre mekânla çok daha fazla ilişki kuracak, anı biriktirecek ve mekânı şekillendirecektir.

Temelde yaşlılık ve mekânın ayn çerçevede konu ediniliyor olması, Türkiye'nin değişen nüfus biçiminin öneml bir sonucudur. Fakat yaşlı nüfus yoğunluğunun genel artışının yanında kent içerisindeki belirli alanlarda da yaşlı nüfu yoğunluğu artarak ayrışmaktadır. Bu bağ lamda Şentürk ve Kurtkapan'ın çalışmasında yer verdiği "yaşlılığın mekânsallaşması" ifadesi durumu özetler niteliktedir

"Yaşlılığın mekânsallașması; kentlerin genelindeki nüfus artışını içermekle birlikte, kent içinde belirli alanlardak yoğunlaşmanın bir sonucu olarak tanımlanmaktadır. Yaşlılığın mekânsallaşmas apartman, sokak, mahalle vb. mekânlar da yaşı nüfusun artması sonucu ortaya çıkan yeni bir durumu anlatmaktadır. Bu çerçevede yaşlıların mekânla kurduğu ilişkiler önemli hâle gelmektedir." (Şentürk ve Kurtkapan, 2017, s. 5)
Henri Lefebvre’nin Mekân Kuramı

Marksist mekân kuramının temsilcilerinden Lefebvre'nin, kent ve mekân konularında önemli çalıșmaları bulunmaktadır. Toplumu açıklarken mekânı merkeze aldığı Kentsel Devrim eseri dünya çapında meydana gelen değişiklikleri irdelemesi yönüyle temel bir metindir. 'Mekânın üretimi' isimli eseriyle mekân tartışmalarına Marksist perspektifle hizmet etmiş, Marksist teoriye mekânın farklı boyutlarını dahil etmiştir. (Ghulyan, 2017, s. 2).

Lefebvre'in, kent okumalarına, mekânsal katkılarına dair temelde Marksist bakış açısını taşıyor ifadesi, onu açıklamakla birlikte yetersiz kalacaktır: Lefebvre kendi analizi içerisinde üretim kavramını "sosyal üretim” biçiminde genişletmiştir. ... "Mekânın üretim yöntemlerinin" veya mekânsallaşmanın tarihi Marx'ın kentsel, çevresel ve tutumsal olana dair vizyonunu tamamlamıştır. Lefebvre'e göre gerçek bir komünist devrim, sadece işçilerin üretim araçları ile olan ilişkilerini değistirmemelidir, aynı zamanda yeni bir mekânsallaşma yaratmalıdır; özel mülkiyet, kent içerisindeki parseller ve topografyaların 1zgara sistemlerinin temel örneklerini oluşturduğu "tasarlanan mekândan" uzaklaşmayı sağlamalıdır. (Hubbard \& Kitchin, 2021, s. 482)

İkinci Dünya Savaşı sonrası toplumların yeniden yapılanma içerisine girdiği süreç yeni yerleşim yerlerinin topluca ve hızla üretimine tanıklık etmektedir. Şehrin çeperine dar alanlara toplu konutların inşa edilmiştir. Kişiler doğal şehirleşme 
sürecindeki istediği alana ihtiyaçlarına göre mekân seçimi aksine, birbirini tanımayan insanların bir araya getirildiğ yeni yerleşim alanlarına yerleştirilmişlerdir. Yaşam alanını seçme hakkına sahip olmayan insanlar bir anlamıyla da dayatılan mekânları kabullenmek durumunda kalmıştır. Henry Lefebvre, bu süreci "mekânın üretilmesi” kavramıyla açıklamaktadır (Poyraz, 2011, s. 16).

Lefebvre "mekânın üretilmesi" kav ramı üzerinde durmasının temel anla$\mathrm{m}$, toplumsal ilişkilerin yeniden üretilmesini sağlamasıdır. Aynı zamanda toplumsal ilişkiler de mekân üretirken, bunu kapitalizm kıskacında tamamlamaktadır. Kapitalizmin mekânları, insanların yaşam alanı olarak, doğayla bütünleşik, kolayca benimsenen, kendi düzenlerine göre yarattıkları mekânlardan farklı olarak, metalaşan mekânlara dönüşmektedir. Endüstri toplumu ile yaşam alanlarının ve mekânların parçalanması söz konusu olmuştur. Nitekim şehirlerin yeni düzenler üzerine kurulması, yeni planlamalar yapılması ile, bireylerin kendi kullanımına, ihtiyaçlarına ve zevkine uygun mekânlar yerini, kapitalizmin yaptığı çimento mekânlara bırakmaktadır. Lefebvre'de mekân kav ramı, ev, evin dışı ya da sokakları içermektedir; yaşama anlam veren yerler, başkalarıyla ilişki içinde olduğumuz alanlar mekânı anlatmaktadır.

Lefebvre'in mekân kuramında en önemli kısımlardan birini "ssehir hakkı” kavramı oluşturmaktadır. Endüstri- leşme ve kapitalizmin etkisiyle mekânların parçalanması sonucunda, şehrin merkezi çeperinde yaşam alanları oluşturularak kentsel dokuda kopuşlar meydana gelmiştir. Banliyölerde yaşayanların şehir hakkından yararlanamaması problemini açıklamak için Lefebvre, bu kavramı kullanmaktadır. Herkesin şehir hakkından faydalanabiliyor olması, doğal hayatın bir gerekliliğidir. Her insanın yaşadığı şehrin üzerinde hakları vardır, insan hakları, özgürlük hakları gibi, şehir hakkı herkesin hakkıdır. Bu bağlamda şehir hakkı, kentsel yaşama hakkı olarak formüle edilebilir (Lefebvre, Şehir Hakkı, 2020, s. 132).

Lefebvre'ye göre her toplumun kendi mekânsal pratiği vardır ve bu mekânsal pratiklerle kendi mekânını yaratmaktadır. Kişiler mekânsal pratiklerini fiziksel çevre (yollar, binalar, özel alan) ve gündelik hayatın tamamı oluşturmaktadır (Ghulyan, 2017, s. 22). Bu çizgide, Lefebvre sistematiğinde mekân, mekânsal pratikler üzerinden okunabilmektedir. Gündelik yaşam pratikleri bu bağlamda, mekân okumalarının önemli bir veçhesini içermektedir. Lefebvre'in de dediği gibi: "Gündelik yaşamın bütün faaliyetlerle derin bir ilişkisi vardır, farklılıkları ve çatışmalarıyla onları kapsar; onların buluşma yeridir. Hem bağıdır hem ortak alanlarıdır. İnsanı -ve her insan varlığ1n1- bir bütün oluşturan ilişkiler bütünü gündelik hayatta şekillenir ve oluşur... “ (Lefebvre, 2015, s. 103).

\section{Pierre Bourdieu}

20. yüzyılın önemli sosyologlarından Pierre Bourdieu, toplumsal açılamalara getirdiği bütüncül yaklaşımlarla ön plana çıkmaktadır. Bourdieu, bireyi açıklarken toplumu, toplumu açıklarken de bireyi göz ardı etmeyerek, bireyi yaşadığ mekânla kurduğu ilişkilere odaklanarak yorumlamaktadır. Bourdieu, bireyin davranışlarını anlamayı ve sosyal olana ilişkin düşüncelere açıklık getirmeye odaklanmış; bu çerçevede alan, habitus ve sermaye kavramlarını analizlerinde ön plana çıkarmıştır (Dursun, 2018, s. 118).

Bourdieu metodolojisinde ortaya koyduğu önemli bir kavram olan 'kültürel sermaye' kavramı, sermaye biçimlerinin kültürel anlamlar da içerdiği yorumuyla ortaya koyduğu yeni bir açılama özelliği göstermektedir. Kültürel sermaye, eğitim yoluyla elde edilen, ekonomik sermayey elinde bulunduran egemen sinıfa alternatif olarak, toplumsal düzende söz sahibi olma imkânı tanıyan sembolik gücü ifade etmektedir (Hubbard \& Kitchin, 2021 s. 146). Bununla birlikte Bourdieu'da habitus kavramı, toplumsal yapıyı açıklarken kullandığı önemli bir kavramdır Bu kavram çeşitli düşünürler tarafından kullanılsa da Bourdieu'nun habitus kavramı kadar kapsamlı olmamıştır. Bourdieu'nun habitus kavramı, temelde, 'habita'dan, yani oturulan yerden bağımsız olmayan, edinilmiş alışkanlıkların, hep aynı biçimde gerçekleşmesi ve devamlılı̆ğ sonucunda, bedende cisimleşmesi sonucunu ifade etmektedir (Kaplan \&
Yardımcıoğlu, 2020, s. 27). Bu bağlamda habitus, içinde olduğun kültürün zihnine işleyen motiflerini; bir mekânda yaşarken, salt o mekânda olmaktan ziyade, bir ilişki ağında olmayı anlatmaktadır.

Mekânlar sosyal yaşamın asli parçalarıdır, bireydendir ve bireyden etkilenendir. Bu bağlamda bedenin mekân ile yakın ilişkisini açıklamakta habitus kavramı önemli bir rol oynamaktadır. Habitus kavramının sosyomekânsal değişimlere de açılılı getirmesi, kentsel mekân çalışmalarında kullanılmasının en önemli sebeplerindendir (Hubbard \& Kitchin, 2021, s. 149).

\section{Edward W. Soja}

Edward W. Soja'yı en genel ifade ile, mekân üzerine çalışmalarını postmodern eleştiri çerçevesinde ele alan Çağdaş Kuramcı ve coğrafyacı olarak tanımlayabiliriz. Soja, kenti postmodern bir mekân olarak kavramsallaştırmasıyla ön plana çıkmaktadır (Özdemir, 2010, s. 72). Lefebvre, Harvey ve Soja'nın Marksist yazını geliştiren mekân perspektifleri, pozitivist yaklaşımın geometrik uzamdan ibaret mekân açıklamasını çok yönlü bir alana taşımıştır. Bu eleştirel teoride mekân sadece sosyal olayların gerçekleştiği bir alan değil, bu süreçlerin hem parçası hem de başlı başına bir etken konumundadır. Mekân, sosyal süreçleri etkileyen ve etkilenen iki yönlü bir etkileşim alanı olarak yorumlanmaktadır (Kaygalak, 2011, s. 5). 
Çağdaş kuramlarda kentin mekânlarının devamlı değiştiği açıklaması ve insan ürünü olan yapay alanlar olduğu söylemleri, sanayileşmenin kentleşmeyi etkilediği gibi kentleşmenin de sanayileşmeyi getirdiği açıklamalarının arka planını oluşturmaktadır. Soja'nın çalışmaları, sosyal yaşamın mekân temelli okunabildiği açılamaların sahibesi Neo-Marksist kuramcilarla paralellik göstermektedir. En çok etkilendiği isim Henri Lefebvre'dir. Sosyal teorinin her unsurunun içinde mekâna yer verilmesi gerekliliği düşüncesi, Soja'nın mekânsal açıklamalara dair katkılarındandır. Soja'nın Postmodern Coğrafyalar isimli kitabı da bu temelde, mekânsal, postmodern bir sosyal teori açılamalarının okuyucuya sunulduğu etkili bir yapıttır. Mekânsal postmodern sosyal teori için kavramsal bir temel oluşturmaya çal1şan Postmodern Coğrafyalar çalışması; tarih yerine mekânın üretimi merkeze alarak kentleşme süreçlerini inceleyen Lefebvre'in mantıksal çerçevesi üzerine inşa edilmiştir (Hubbard \& Kitchin, 2021, s. 646-649).

Mekân toplumsal ilişkilerin, süreçlerin ürünüdür ve aynı zamanda o ilişkileri etkileme gücüne de sahiptir. Soja perspektifinde mekân, gündelik hayatın rutinlerinden üretilen mekânsal pratiğin biçimlerini içermektedir. Mekânsal pratikler kendini algılanan mekân üzerinden kurmaktadır ve toplumsal üretim ilişkileriyle bu algı yeniden ve yeniden üretilmektedir (Gülhan, 2013, s. 58).

\section{Doreen Massey}

Doreen Massey'in biyografik bilgileri ve kuramsal bağlamından söz edecek olursak, 1944 yılı Manchester'ında doğmuş, coğrafya, sosyoloji ve kültür çalışmaları alanlarında en önemli isimlerden birisidir. Massey',n perspektifi, coğrafyayı sosyal alanda incelenebilir bir bilim dalı olmasının tasavvurunu yapmış, mekânın kavramsallaştırılmasının önemi üzerinde durmuştur. Ona göre mekân kavramı için oturtulan teorik zemin, kişinin algılarını ve mekâna dair dönüşümlerin etkisini belirlemektedir (Hubbard \& Kitchin, 2021, s. 511-512).

Massey araştırmalarında mekânın sürekli bir değişim içinde olduğu meselesini temel almaktadır. Bu değişimlerin unsurları tek değildir, insanlar, hayvanlar, şehirler doğa gibi her canlı ya da cansız nesneler bu değişim çarkının dişleri konumundadır. Mekânlar işte tüm bu unsurların var olduğu, değiştiği ve ilişkilerine imkân tanıdığı yegâne yerlerdir (Zeybek, 2016, s. 9). Mekânın çok yönlü bir kavram olması, ona dair getirilen yorumlar ve çalışmaların da çeşitliliği üzerinde etkili olmaktadır. Bu konum mekânla ilgili konuları hem değerli kılmakta hem de ortak bir tanımda buluşabilme şartlarını zorlaştırmaktadır. Mekânın mühendis-mimar için farklı bir tanımlaması; çevre bilimci ya da coğrafyacı için farklı bir açıklaması; psikolog ya da sosyal bilimci için apayrı bir yorumu olabilmektedir. Doreen Massey'in coğrafyacı ve sosyal bilimci kimliğiyle mekân kavramını değerlendirmesi bu bağlamda, alana dair çalışmalar için son derece değerli bir profil çizmektedir.

Lefebvre'in 'toplumsal uzam, toplumsal bir üründür' görüşü ve Doreen Massey’in 'karş1lıklı ilişkilerin ürünüdür' söylemi, mekânın üretilen bir alan olduğu görüşünde hem fikir olduklarının en açık göstergelerindendir (Vurmay, 2010, s 209). Massey'in üzerinde en çok durduğu konu mekânın çok yönlülüğü ve mekânda ilişkilerin devamlılığıyla, değişim ve dönüşümünün sürekliliği üzerinedir Mekâna getirilen zamana bağlı değişim açıklamaları, Massey tarafinca eleştirilmiştir, mekânı tek bir yönle açıklamanın her bakımdan yetersiz kalacağı vurgusu yapılmıştır (Bilgili, 2016, s. 12). Mekânlar için asıl olan benim düşüncemdir, benim mekânım benim ürettiğimdir; hem benim tasavvurumdaki hem dış etmenlerce hem benim tarafimdan tasarlanan, dönüştürülen yegane yaşam alanlarıdır.

\section{Araștırmanın Tasarımı}

\section{Araştırma Konusu}

Bu araştırma, Türkiye'de uzun vadede değișen aile yapısı ve nüfus piramidi çerçevesinde, yaşlıların mevcut durumunu göz önünde bulundurarak, yaşlılık döneminde mekân ile nasıl bir ilişki kurulduğu, mekâna ilişkin beklentiler ve yaşlı bireylerin gündelik pratiklerinin mekâna bağlı olarak nasıl şekillendiğ meselesini konu edinmektedir. Bu bağlamda mekân sosyolojisi ve yaşlılık sosyolojisi disiplinleri incelenmiştir.
Yaşlılık sosyolojisi ve mekân sosyolojisi harmanlaması ile yaşlılık ve mekân merkezli bir çalışma ortaya çıkarılmıştır. Yaşlılık ve mekân konuları çalışmaya bir çember oluşturacak biçimde konumlandırılmış, bu çerçevede 65 yaş ve üzeri bireylerle derinlemesine görüşmeler yapılarak, yaşlıların mekân ile ilişkisi merkeze alınmıştır. Kentte yaşayan yaşlıların, mekân ile ilgili memnuniyetleri, mekân aidiyetleri, mekânsal değişimle ilişkileri, mekânın yaşlılar için sunduğu imkânlar, mekânın yaşlılar için niteliği, bu araştırma için temel konuları oluşturmaktadır.

\section{Araştırmanın Amacı}

Toplumsal gelişmeler, temelde kentleşme ve mekânsal değişimler, yaşlılar için yeni yerleşim alanları oluşturmuştur. Hemen hemen her yaşlı birey, doğduğu beldede, memleketinde yaşama şansını ya da isteğini gerçekleştirememektedir. En başta ekonomik kaygılar yer almak üzere, çevresel koşullar, aile birlikteliği devamı ve çeşitli sebeplerle, farklı yaşam alanlarına yönelerek yeni yerler yurt edinilmiştir. Yaşlılar için de yeni mekân, yeni kültür, farklı gündelik pratikler ve ilişkileri beraberinde getirmiştir. Yaşlılık ve mekân konulu bu araştırma temelinde, Türkiye'nin yaşlı nüfus yoğunluğunun hızla arttığı bir şekle evirilen nüfus piramidine yönelik bir farkındalık oluşturmak, toplumda pek fazla söz hakkı bulamayan yaşlı bireylerin toplumsal alandaki yerini, benliklerini ve tüm ilişkilerini şekillendiren kentsel mekânın etkilerini incelemek amaçlanmıştır. 
Çalışmanın amacına ulaşmasına yönelik, temel araştırma soruları çerçevesi oluşturulmuş, bu sorular çeşitlendirilerek, mülakat çalışması tasarlanmış olup derinlemesine görüşme metoduyla mülakatlar yapılmıştır. Sorular oluşturulurken Türkiye'de yaşlılara ve mekâna ilişkin konularda nitel ve nicel veriler incelenmiştir. Araştırmanın amacına uygun sorulan sorular ve yapılan görüşmeler neticesinde elde edilen bulgularla, ulaşmak istenilen sonuca uygun değerler elde edilmiştir.

\section{Projenin Kapsamı}

Araştırma kapsamında nitel araştırma yöntemleri planlanmış olup mülakat tekniğinden faydalanılmıştır. Araştırmanın konusuna yönelik literatür incelenmiş, birçok makale, tez ve kitap taraması yapılmıştır. Araştırmanın temel kavramlarını, "yaşlılık, mekân ve mekân algısı, mekânın üretimi” oluşturmaktadır. Çalışmanın içeriğine yönelik yine bu kavramları esas alan referanslar seçilmiş, geniş ölçekli bir literatür taramaya yer verilmiştir.

Araştırmanın, yarı yapılandırılmıs görüşme metodu kullanılarak soruların açık uçlu sorulardan oluşması ve soruların görüşme kılavuzu takip edilerek yöneltilmesi amacı temel alınarak yaşl bireylerle 37 sorudan oluşan, derinlemesine görüşmeler yapılmıştır. Çalışmanın içeriğinde örneklem seçilen, Kadıköy ve Bağcılar İlçelerinde ikamet eden yaşl bireyler için rahat bir görüșmeye uygun ortam hazırlanmış, on kişi ile yapılması planlanan mülakatlar tamamlanmıştır. Yaşlı ve mekân ilişkisini ölçümlemek üzere 65 yaş ve üzeri bireylere yöneltilen soruların içeriğini, ev içi ve çevre mahalleyi okumayı temel alan soru türleri geliştirilmiştir. Çalışmaya katılımın gönüllülük esasına bağlı olması ön planda tutulmuştur.

\section{Yöntem}

Araştırma kapsamında nitel araştırma metotlarından faydalanılması ön görülmüsstür. Nitel araştırma modeli, olguları bütüncül bir yaklassımla inceleme ve irdeleyici bakma imkânı sağladığı için bu araştırma temelinde uygun görülmüştür (Punch, 2011, s. 183).

\section{Teknik (Veri Toplama Aracı)}

Mülakat tekniğinden yararlanılmıştır. Araştırma kapsamında örneklem seçilen 65 ve üzeri bireylere mülakat soruları aktarılmış, yanıtlar alınmıştır. Böylece zamanının birçoğunu evde geçiren, aynı mekânlarla uzun süreli ilişkiler kurma imkânı bulan yaşlı bireylerin, mekânla ilgili deneyim ve düşüncelerine yönelik veriler elde edilmiştir (Şentürk ve Kurtkapan, 2017, s. 9).

\section{Araştırmanın Varsayımı}

Yaşlılık konusu ve bu başlık altında ele alınan mekânsal yaşlılık konusu yalnızca yaşlı olarak tanımlanan bireyleri değil, toplumun her alanını ilgilendirmektedir. Toplumun her parçasını birbiriyle anlamlı bir ilişki içerisindeki örgüler gibi düşünebiliriz, bu nedenle herhangi bir olgudan bahsederken onu diğerlerinden ayrıştırmak mümkün olmamaktadır, birini çekip almak digerlerini de beraberinde getirmektedir. Toplumumuzdaki yaşlılık ve mekânsa ilişki meselesi de modernleşme süreci küreselleşme, aile kurumu, gelenek ve görenekler, toplumsal normlar, eğitim ekonomi vb. gibi pek çok alanla iç içe bir konumda yer almaktadır. Yaşlılık ve mekân konuları, ayrı ayrı interdisipliner alanlar olma özelliği göstermektedir. Yaşlılık başta sosyoloji, psikoloji, sağlık, sosyal hizmet ve ekonomi bilimleri için önemli araştırmalara konu olmaktadır. Nitekim mekân da konusu itibari ile sosyoloji, mimarlık, inşaat ve tasarım alanlarında farklı bakış açıları ile ele alınmaktadır. Bu araştırma yaşlılık ve mekân ilişkisini mikro ölçekte ele alarak mekân ile yaşlı birey arasındaki ilişkiyi, mekânsal yaşlılık bazında incelemeye çalışmaktadır. Yaşlı bireylerin mekâna karşı tutumunun yaşlılar üzerinde etkin bir rol oynadığı görülmektedir. Nitekim yaşlıların mekânla ilgili paylaşımları yaşlılık döneminde ev ve yakın çevre odaklı arttığı gözlemlenmektedir. Bu bağlamda mekân ve mekânla kurulan ilişkiler mekânsal değişimlere bağlı olarak, yaşlılık pratiklerini etkilemektedir.

\section{Bulgular}

Mülakatlarda araştırma soruları sunulurken, katılımcılara kimliklerinin gizli tutulacağı bilgisi verilmiş, güvenilirlik ortamı sağlanmıştır. Bu bağlamda araştırmaya katılan kişilerin görüşleri aktarılırken, isimleri gizli tutulmuş, tak- ma adlara yer verilmiştir. Nitel araştırma yöntemi tercih edilen araştırmalarda en önemli ve meşakkatli bölümlerden birisi verilerin analiz edilmesi aşamasıdır. Nitel araştırma yönteminde elde edilen verilerin sistematik hale getirilmesi, kodlanması ve bulguların yorumlanarak analiz edilmesi gerekmektedir. $\mathrm{Bu}$ araştırma için yapılan görüşmelerdeki edinimler bir metin oluşturularak yazıya dökülmüss, araştırma formatına göre elde edilen cevaplar sinıflandirılarak ardından yorumlanmıştır (Böke, 2014).

Yașamsal Yeterlilik Mekânı Olarak İstanbul: Türkiye kentleşme tarihinde, köyden kente yoğun göçlerin olduğu, 60-70'li yıllar, görüşmecilerin birçoğunun da İstanbul'a geldikleri tarihlere işaret etmektedir. Katılımcıların verdiği cevapların hemen hepsinde İstanbul'a yerleşme tarihi 30 yılı aşkın süreçleri kapsarken, sebepler ortak bir noktada toplanmaktadır. Katılımcılar, İstanbul'a yerleşme sebeplerini 'iş bulma' beklentisi ve İstanbul'da birçok imkân bulabileceği umuduyla memleketinden göç ettiğini ifade etmiştir.

Mekânların yaşam alanı olarak inşa edilmesinin ne önemli etkenlerinden biri de o mekânın bireylere sunduğu imkânlardır. Bu çalışma için seçilen iki semti kapsayan kent mekânı olarak İstanbul, yıllar boyunca gözde şehir unvanına sahip olmuş, hala da bu niteliği devam ettirmektedir. İstanbul ili bu yönüyle, tarih boyunca göç alan bir mekânsal özelliğe sahip olmuştur, hala da göç almaya de- 
vam etmektedir. Ülkemizdeki kentleşme hareketlerinin özellikle 1950'lerden sonra yoğunluk kazandığını söyleyebiliriz. İntansif tarıma geçilmesi, kırsal nüfusuı devingenliği üzerinde etkili olmuş, meydana gelen yapısal dönüşümler kırsal alandan kentsel alana göçün söz konusu olmasını neden olmuştur. Ulaşım olanaklarındaki ve kitle iletişim araçlarındaki gelişmeler de yatay hareketliliğin hız lanmasında etkin rol oynamıștır. Kentsel alanda gündeme gelen yeni iş olanaklar ve daha iyi yaşam koşulları da kent üzerinde yapısal değişimlerin tohumların ekmiş, bunun sonucunda kırsal nüfusu kendine çekerek, kentsel nüfusun, toplam nüfus içindeki oranının hızla artmaya başlamasina sebep olmuştur (Dülge roğlu- Yüksel \& Kerem, 1998, s. 50).

Dayanışma İhtiyacına Çözüm Olarak Akraba Yanını Mesken Seçme: Araştırma kapsamında genel itibariyle yaşlı bireyler, mekân tercihlerini, hiç bilmedikleri, yenilikler veya farklılıklar içeren yerler üzerinde yapmamış, ahbaplarının, çocuklarının veya akrabalarının yaşadığı mekânları tercih etmiştir. Mekânda bir yakınının olması, güven duygusu vermesi ve dayanışma ihtiyacının tatminini sağlamaktadır. Katılımcılara yöneltilen, İkamet ettikleri alanı seçmelerinin üzerinde etkili olan sebep sorulduğunda, hemen her bireyden, evvela bir yakının orada olduğu cevabı alınmıştır. Bireyler dayanışma ihtiyacına çözüm olarak akraba yanını mesken seçmeyi tercih etmektedir.
Yaşadığın mekânda yakın çevrenden kişilerin ikamet ediyor olması, mekânı kişiler için tercih edilir olması üzerinde bir etkendir. Aynı zamanda yaşlılık döneminde yakın çevreyle ilişkilerin çok daha önem kazandığını söylemek yerinde olacaktır. Ahbap, akraba ve çocukların, yaşl1lığa uyum sağlamada rolü önemlidir. Ailenin ve tanıdıkların yakınlığı, sevenlerinin desteği, yaşlılarda yaşam doyumu üzerinde etkili olmaktadır. Dayanışma imkânının varlığı, kişilerin kedini daha güvende hissetmesini ve psiko-sosyal açıdan tatmin olmasını sağlamaktadır. Bireylerin yakın çevreyle daimî ilişki içinde olma, aile, arkadaş ve akraba bağlarına, bunlardan gelen koşulsuz sevgiye olan ihtiyacı mütemadiyen devam etmektedir (Ceylan, 2015, s. 56). Bu ihtiyaca çözüm olacak ki, taşınma, göç etme gibi mekânsal değişiklik durumlarında akraba yanını mesken seçme durumu tercih edilmektedir.

Mekân İçin Aranan Özellik: Mahalle Kültürünün Varlığı: Bağcılar ve Kadıköy semtleri için karşılaştırma yapacak olursak, her iki mekânın da sakinleri mahalle kültürünün varlığından istenilen ve aranan bir özellik olarak bahsetmektedir. Bununla birlikte katılımcıların, komşuluk, ilişkileri, gündelik pratikleri, kimlerle yakın ilişki kurabildiği sorularına verilen yanıtlardan yola çıkılacak olursa; Bağcılar'da esnaf, mekânsal değişimlere rağmen kendini ve insanlarla ilişkilerini koruyabilmiştir, Bağcılar semtinde Kadıköy'e göre mahalle kültürü nispeten varlığını devam ettirmektedir.
Kadıköy'de ikamet eden bireylerin çoğunluğu, İstanbul'a ilk göç ettiklerinde orayı tercih etmiş ve aynı muhitinde oturmaya devam etmektedir, ancak Bağ cılar'da yaşayan katılımcıların çoğunluğu Bağcllardan önce farklı bir muhitte varlık göstermiştir. Uzun süredir ayn yerde ikamet ediyor olmanın çevre ile daha yakın ilişkiler kurmaya olanak sağ layacağı varsayımı geçerli olmamaktadır. Yaşlılık dönemindeki bireyin, ölüm taşınma, kentsel dönüşüm vb. sebeplerle komşu, yakın çevre üzerinde kayıplar yaşaması, yalnızlaşmasına sebep olmaktadır. Eşini kaybetmiş yaşlı bireyler yalnız yaşayarak hayatını devam ettirmektedir.

Mekânda Memnuniyetin Temel Yapıtaşı: Alışılmışlık: Bağcılar ve Kadıköy ilçelerinde ikamet eden katılımcılara yöneltilen mekânla ilgili memnuniyet düzeylerini ölçmeye yönelik sorularda bireyler yüzde yüz oranında "memnunum” cevabını vermişlerdir. Konula irdelendikçe mekâna dair eleştirel yaklașımlar olsa dahi, senelerdir aynı muhitte oturmak, o mekâna "alışmış" olmak, o mekâna aidiyet ve memnuniyet düzeyini doğru orantıda etkilediği görülmektedir.

Yaşlılıkta Eski Mekânlara Özlem: Yaşlılık döneminde, çeşitli sağlık problemleri, eski imkânların bulunamaması gibi sebeplerle, geçmişte ilişki kurulan mekânlara özlem duyulmaktadır. Yeni mekânın sunduğu imkânlar, yeni düzenler var olsa dahi, Kadıköy yahut Bağcılar ilçesi katılımcıları fark etmeksizin, eski mekânların hatıraları zihinlerde yerini korumaktadır.
Mekânlar mimari yapılarının yanı sıra, sosyal ve sembolik düzeylerde birbiri ile ilişki içerisindedir (Kalınkara \& Arpacı, 2013). Katılımcıların açıklamaları ışığında, mekânlar, yaşlı bireyler için de anlam yüklü, yaşayan, yaşatılan özlem duyulan alanlardır.

Yaşlılar İçin Buluşma Mekânı Olarak: Cami: Camiler, Türk toplumu için, tarih boyunca önemli bir imgesel ve simgesel özelliğe sahip olmuştur. Bu araştırma için irdelenen kısım, camilerin yaşlı bireyler için buluşma mekânı olarak tercih edilmesi ve camiye yüklenen nosyonun niteliği üzerinedir. Erkek yaşlı bireyler gündelik pratiklerinde zamanlarının çoğunluğu camide ya da cami cemaati arkadaşlığıyla paylaşımlarda geçirmektedir.

"Yaşlanma ve Mekân İlişkisi Üzerine: Türkiye'de Yaşlı Erkek Bireylerin Camii ve Kahvehane Kullanımlarının Analizi” (Esendemir \& Sağman, 2019) Araştırmasında yer alan bulgulara göre, görüşme yapılan 30 yaşlı bireyin 19'u düzenli olarak günlük camiye gittiklerini belirtmişlerdir. Bu 19 bireyden sadece 8'i emeklilik öncesi de camiye gittiklerini söylemişlerdir. Bu bağlamda yaşlılık döneminde, cami, yeni mekânsal tercihler arasında yer almaktadır. Yaşlı bireyler camiyi bir sosyalleşme alanı olarak tercih etmektedirler. Yaşlı bireyler için cami ve cemaat arkadaşlığı -ailenin dışındaki en büyük sosyal destek kaynağı olmaktadır (Esendemir \& Sağman, 2019, s. 26). Cami, yaşlılar için temel uğrak noktaları arasında önemli bir alana karşılık gelmektedir, literatür de bunu destekler niteliktedir. 
Yaşlı Bireylerin En Büyük Yardımcıs1: Çocuklar: Araştırma sorularında ye alan: "Maddi- manevi bir ihtiyaç durumunda kimlerden yardım istiyorsunuz? sorusuna katılımcılar genel itibariyle “çocuklarımdan” cevabını vermiştir.

Perde Arkasında Kalan Ayrımcilık Türü, "Yaşçılık” Farkındalığının Noksanlığı: Araştırma soruları arasında yer alan, "Yaşınızdan dolayı ayrımcı bir dav ranışa maruz kaldığınız oldu mu?" sorusu yöneltildiğinde, katılımcılar genel itibariyle böyle bir tutumla karşı karşıya kalmadıklarını ifade eden açıklamalarda bulunmuşlardır.

Gündelik Hayat Pratiklerinde İkincil İhtiyaç Olarak Sosyal Medya, Akıll Telefon, TV Kullanımı: Yaşlı bireyler, gündelik pratiklerinde teknolojik araçlarda veya sanal mecralarda vakit geçirmek yerine, daha çok gazete ve kitap okumak, camiye gitmek, market gez mek, yürüyüş yapmak gibi aktivitelere yer vermektedir. "Akıllı telefon, sosyal medya kullanıyor musunuz?" sorusuna verilen cevaplar, yaşlı bireylerin ihtiyaç dışında telefon vs. kullanım oranlarının düşük olduğunu göstermektedir.

Yaşlılıkta Bir Bağımlılık Türü: Sürekli İlaç Kullanımı: "Yaşadığınız bir sağlık problemi ya da sürekli kullandığınız bir ilaç var mı?" sorusu yöneltilen yaşlı bireyler, genel itibariyle sürekli ilaç kullanımına mahkûm olduklarını ifade eden yanıtlar vermişlerdir. Sürekli ilaç kullanımı, yaşlı bireylerde hayat kalitesini olumsuz etkileyebilmektedir. İlaç kullanımının gerekli olduğu durumların yanı sıra, ihtiyaç olmadığı durumlarda da kullanılmas1, hem sağlıklarını tehdit edici bir unsur oluşturmakta hem de bu çaresizlik yaşlılık hissine sebep olmaktadır. 'Yaşlıyım tabi ki ilaç kullanacağım' kanısı, katılımcıların sahip olduğu genel görüşü ifade etmektedir.

Gündelik Hayatın En Uzun Zaman Geçirilen Mekânı Evler: Yaşlılık döneminde en uzun zaman geçirilen mekânlar arasında evler yer almaktadır. Evin içerisinde yer alan eşyalar da yine en çok ilişki kurulan ve anlam yüklenen nesneler olarak karşımıza çıkmaktadır.

Katılımcılara yöneltilen "Evinizde en değer verdiğiniz, sizin için önemli bir yeri olan eşyanız nedir?" sorusuna verilen cevaplar, kişiler için ev ortamın kişisel zevklere göre tasarlanan, üretilen ve yaşatılan mekânlar olduğunun bir göstergesidir.

Yine katılımcılar, kendilerini hangi mekânlarda rahat hissettikleri sorusuna, genel itibariyle ev ortamı cevabını vermiştir. Bu bağlamda şu çıkarımda bulunmak yerinde olacaktır ki, yaşlı bireylerin, kendilerini ait hissettikleri mekân yine kendi evleridir.

Mekân Aidiyetinin Mihenk Taşı Komşuluk İlişkileri: Kentlerde, ortak mülkiyete dayalı ilişkilerin yer aldığı, aynı apartmanda yaşayan bireyler "komşu" olarak tanımlanmaktadır (Özbay, Akrabalık ve Komşuluk İlişkileri, 2014). Komşuluk, Türk kültüründe değer verilen, üzerine sosyolojik çokça çalışma yapılmış, insan ilişkililerinde önemli bir etkileşim unsuru olarak karşımıza çıkmaktadır. Hızlı kentleşmenin yaşandığ ve köyden kente yoğun göçlerle oluşturulan yeni yerleşim alanları itibariyle kültürümüzde komşuluk ilişkilerinde "hemşerilik" de aranan bir alt unsur olarak karşımıza çıkmaktadır. Katılımcıların araştırma sorularına verdiği cevaplarda, hemşerileri ile yakın çevrede otur maktan, onlarla komşuluk yapmaktan memnun oldukları saptanmaktadır.

Demografik özellikler çerçevesinde de ğerlendirme yapılacak olursa, erkek yaşı bireylerin, kadınlara oranlara komşuluk ilişkilerinde daha zayıf ilişkiler yürüttükleri söylenebilir. Erkek bireyler genel olarak cami cemaati arkadaşlığı kurarak gündelik hayatlarını şekillendirmişlerdir. Ancak kadınlar, komșuluk iliskilerinde erkeklere oranla daha sık görüssebilen, paylaşımda bulunabilen bir portföy çizmektedir.

Yaşadığı mekândan mutlu ve memnun olduğunu ifade eden bireyler, bu çıkarımda bulunurken, düşüncelerini komşuluk ilişkilerinin yakın olması ile de iliskilendirerek desteklemektedir Bir mekânda komşuluk ilişkilerinin de vamlılığı, o mekâna aidiyeti ve memnuniyeti de yüksek oranda etkilemektedir. Araştırma temelinde, yaşlı bireylerin komșuluk ilișkilerini kısmen devam ettirebildiklerini söylemek mümkündür. Komşuluk ilişkileri devam ettirilebilsin ya da ettirilemesin, bir mekân için aranan özellik statüsünü korumaktadır. Nitekim, komşularıyla gündelik hayat pratiklerinde ilişki kuramayan bireyler, bunu bir eksiklik olarak ifade ederken, komşularla yakın ilişki kurulabilme durumu, övgü duyulası ya da eksikliği hissedilen bir özellik olarak bahsedilmektedir. Aynı zamanda komşuluk ilişkilerinde yakınlık, yaşlı bireyler için, yalnızlığın giderilmesinde önemli bir husus olarak karşımıza çıkmaktadır.

Yaşlılıkta Sevilen Fakat Gezme İmkânı Bulunamayan Mekânlar: Katılımcıların verdiği cevaplar neticesinde söylemek mümkündür ki: Yaşlılıkta daha çok, gezmeye ve dışarıda vakit geçirmeye ayrılan zaman kısıtlı olmaktadır. Bununla birlikte, yaşlı bireylerin gezme mekânlarında, tercihen dini ritüellerin gerçekleştirildiği, cami, türbe, mabet, kabristan gibi yapıların yer aldığı bölgeler ön plana çıkmaktadır. Mekânsal olarak yaşanılan yerin, kalabalık, sakin olması ya da konumu, yaşlılıkta gezebilme durumunu nispeten etkilemektedir. Kadıköy'de yaşayan yaşlı bireyler, sahil kenarı ve park gibi mekânlara daha yakın mesafede yer almasından dolayı olacak ki, gezintiye çıkabildiğini ve bu tarz mekânlardan hoşlandığını belirtmiştir. Yaşadığın mekânın sunduğu imkânlar, gündelik hayatı, paylaşımları, istekleri ve zevkleri etkilemektedir.

Yaşlılık Politikalarına Dair Paylaşımlar: Katılımcıların verdiği yanıtlarda yüzde altmış oranlarında, yaşlılık politikalarından memnuniyet söz konusudur.

Kentsel Dönüşümün Gerekliliği Görüsü ve Kentsel Dönüsüme Bakıș: Kentsel dönüşümün mekân ve birey üze- 
rindeki etkisi yadsınamaz; bununla birlikte, yaşadıkları mekânla uzun süreli ilişki içerisinde olan yaşlı bireyler kentsel mekânın en önemli parçalarından biridir ve yine kentsel dönüşümün etkilerini ölçümleyebileceğimiz bir kitle olma özelliği göstermektedir. Kentsel dönüşümün etkilerinin incelenmesi, kentin fiziksel koşulları ile toplumsal problemleri arasında ilişki kurarak, toplumsal meselelerin anlamlandırılabilmesine imkân tanımaktadır ve kentsel dönüşümün bu etki alanı iyi okunmadığı sürece iyileştirmeye yönelik zanlar yerini yeni problemlerin oluşumuna bırakacaktır.

Yaşlı bireylerin, alışkın olduğu mekânda, tanıdığı, ilişki kurduğu ve güvendiğ kişilerle aynı mekânı paylaşıyor olması büyük önem taşımaktadır. Nitekim bu şartlar altında yaşam doyumu sağlanmas mümkün olmaktadır. Kentsel dönüşüm projelerinin genel itibariyle bu sürece zarar verme olasılığı yüksek ihtimallidir (Ergun \& Dericioğulları Ergun, 2020, s. 129). Ancak araştırma kapsamında yaşl bireylere yöneltilen kentsel dönüşüme yönelik görüşlerde, genel kanı kentsel dönüşümün gerekliliği düşüncesidir.

Yalnızca bir katılımcı kentsel dönüşüm eksikliğini gören açıklamalarda bulunmuş, eski yaşadığı mekândan ayrılmak durumunda kaldığını ifade ederek memnun olmadığını belirtmiştir.

Mekânsal Niteliğin Tanımında: Sakinlik: İstanbul'un Türkiye'nin en kalabalık ili olma özelliği, ilçelerin hemen hepsinde de kendini göstermektedir.
Araştırma sorularında yöneltilen sorular ve alınan cevaplar itibariyle, katılımcıların görüşleri de bu doğrultudadır. Kadıköy ilinde ikamet eden katılımcılar, yaşadıkları mekânı sakinlikle daha çok bağdaştırmaktadır. Bununla birlikte, yeni kentleşmenin unsuru site içinde ikamet eden Bağcılar bölgesi katılımcıları da yakın çevresini, ilçe geneline göre sakin yapılı olarak tanımlamışlardır.

Pandemi Sürecinde Yaşlı Olmak: 2020 yılı itibariyle ülkemizde etkili olmaya başlayan koronavirüs hastalığı, tüm dünyayı etkisi altına almış ve toplumsal alana nüfuz ederek, değişim ve dönüşmeleri beraberinde getirmiştir. Koronavirüs hastalığının, etkileri hala devam ederken, bu sürecin en fazla etkilenen grubunun hasta ve yaşlı bireyler olduğunu söylemek mümkündür. Bu salgın, uzun süreli sokağa çıkma yasağı önlemleriyle birlikte bireyleri, evlerde kalmaya zorunlu bırakmış, yaşam mekânlarını ev içerisinde sınırlamıştır. Pandemi süreci yaşlı bireylerin söylem ve eylemlerde ön planda tutulduğu, en riskli grup tanımlaması ile psikolojik şiddete maruz kalmalarına sebep olmuş, sıkıntılı süreçleri içermektedir (Soysal, 2020, s. 296).

\section{Sonuç}

$\mathrm{Bu}$ araştırma ile kentsel mekânda meydana gelen değişim ve dönüşümlerin, yaşlı bireylerin gündelik pratikleri üzerinde etkili olduğu sonucuna ulaşımıştır. Bilhassa bireylerin içinde bulundukları mekânın özleriyle dokunmuş parçaları kendilerinde taşıdıkları, yine mekânı, kendi nüanslarıyla şekillendirdikleri gözlemlenmiştir. Yaşı bireyler için mekân, emeklilik dönemlerini geçirdikleri, eşleriyle ya da kendi başlarına kaldıkları, yeni bir hayat biçimini benimsedikleri dönemde yaşamlarını şekillendirdikleri yegâne alanlardır. Toplumsa bir ürün olan mekânın, çoğu zaman ikinci plana atılan yaşlı bireyler için de etkileşimi kaçınılmazdır. Bu bağlamda yaşı bireylerin de mekânsallık okumasının yapılması, yaşlı sınıfının ürettiği mekânın biçimi ve mekândan nasıl etkilendikleri, hayatlarını nasıl şekillendirdikleri konusunun çalışılması; toplumsal yapıya yönelik sosyolojik araştırmalarda hem yaşlı bireyler hem de mekân kavramı tartışmalarına hizmet etmektedir.

Yaşlılık ve mekân ilişkisini konu alan bu çalışmada yaşlı bireylerin mekâna yönelik tutumları ile ilgili bulgulara ulaşılmıştır. Yaşlı bireylerin, toplumsal devinimler sonucu kentsel mekânda meydana gelen değişimler karşısında onların da karşılıklı değişime uğradığ ve mekânın yapısını etkilediği sonuçlarına ulaşılmıştır. Burada bahsi geçen mekân kavramı sokak, mahalleden ibaret değildir. Mekân yaşlı bireyin yaşamını sürdürdüğü evi, bahçesi, apartmanı, sokağı aynı zamanda ilçesidir. Yani yaşlı bireyin canlı ya da cansız her varlıkla ilişki kurduğu uzamlardır. Bu bağlamda yaşlı bireyin mekânla kurduğu ilişkiye yönelik bulgular toplanması için parçadan bütüne, gündelik pratiklerin gerçekleştirdiği tüm alanları ilgilendi- ren sorular yöneltilmiştir. Yaşlı bireylerin, mekânsal ilişkilerinin incelenmesi, toplumuzda yaşlı nüfus oranının artış göstermeye başlaması ile araştırılması gerekliliğini göstermektedir. Araştırma bulgulariyla, kentsel mekânda meydana gelen değişim ve dönüşümlerin, yaşlı bireylerin gündelik pratikleri üzerinde son derece etkili olduğu gözlemlenmiştir. Toplumsal bir ürün olarak mekânın, toplumun göz ardı edilen kesimi olarak yaşlılar üzerinden çalışılması, yaşlılık kavramının mekân üzerinden okunması ve yaşlılık üzerine farkındalık oluşturması açsından önemlilik arz etmektedir.

Yaşlılık dönemi, hayatın her evresinde içinde bulunduğumuz koşullarda olduğu gibi artıları- eksileri, zorluklarıkolaylıkları, yeterlilikleri- eksiklikleri içinde barındıran bir süreçten ibarettir. Öte yandan yaşlılık, psiko-sosyal gelişimin devam ettiği ve üretken olunan bir dönemi içermektedir. Hayat boyu edinilen deneyimler, yaşlilıkta problem çözme yeteneğinin son derece gelişmesini sağlamaktadır ve yaşlılık, geniş bir vizyon, bilgi birikimi ile iyi bir sözcük hazinesinin de beraberinde getirildiği bir olgunluk döneminin ifadesidir (Yavuzer, 2020, s. 88).

Ünlü düşünür Cicero'nun yaşlılık ile ilgili görüşlerini bahsettiği eserinde yaşlılık üzerine faydalı açıklamalara ulaşmak mümkündür. Yaşlı ayrımcılığına sebep olabilen ön yargılı tutumların altında yatan olumsuz düşünceleri, yaşlılıkla bağdaştıran görüşlerin aksine, insanın karakteri- 
nin gençliğinde nasılsa yaşlılığında da öyle devam ettiğini açıklamaktadır. Yaşlığın keyifli yönlerini ortaya koymak ve 1 lıml bir yaklaşım benimsemek, yaşlılığa karş çoğunlukla, toplumsal açıdan olumsuzluk larla ilişkilendirmelerin önüne set çekebilmek açısından önemlilik arz etmektedir. Cicero'nun eserinde, yaşlılığa ilişkin tutumu yaşlılık döneminde kişinin üretkenliğinin devamlılığını destekler niteliktedir:

Huzurlu, sorunsuz ve yumuşak bir ömrün yaşlılık çağ 1 da sakin ve rahat geçer Platon'un yaşlılığının böyle olduğunu biliyoruz, öldüğünde 81 yaşındaydı ve son ana dek yazmaya devam etti. Isokrates'in yaşlılığı da böyleydi. Panathenaicus isimli kitabını doksan dört yaşında yazdığını kendisi söylüyor, sonrasında beş yıl daha yaşamıștır. ... Akılsızlar kendi kusurlarını ve suçunu yaşlılığa yükler (Cicero, 2020, s. 10).

Bu bağlamda yaşlılık kavramı, niceliksel olarak 65 ve üzeri bireyler tanımı ile dar anlamda bir açıklamaya tabi olmaktadır. Yaşlılık niteliksel olarak bakıldığında, zıttı görülen gençlik tanımlarını da içeriğinde taşıyabilmektedir, kayıplardan ya da noksanlıklardan münezzeh bir yaşlılık da pekâlâ mümkündür. Bu perspektifle yaşlılık okuması ve çalışılması yaşlı bireylerin topluma entegreleri açısından son derece değerlidir. Bireylerin toplumsal alanda en fazla ilişki içinde oldukları alanlar mekânlardır. Toplumsal devinimler sonucu değişen mekânlar ve yaşlılık statüsünün birlikte değerlendirilmesi, bu çerçevede yaşl bireylerin mekânsal pratikleri okuması; yaşlılık ve mekân gibi iki farklı kavramın bizlere sunduğu ortak çıkarımları gözlemleme imkânı sunmaktadır. Bu araştırma, mekânın birey üzerindeki etkisi ve bireyin mekânı dönüştürme yetisi göz ardı edilmeksizin yeni çalışmalara zemin oluşturmaktadır. Yaşlı bireylerin mekân üzerindeki etki ve etkilenme payı oldukça fazla iken, kamusal alan yahut özel alan fark etmeksizin, yaşlılık tecrübeleri ve bilgeliğinden faydalanılması hem yaşlı bireylerin yaşam doyumunu artıracak hem de toplumsal alanla bütünleşme sağlanarak genel çerçevede iyi ilişsiler kurulmasına zemin sağlayacaktır.

\section{Kaynakça}

(2021). TUIK: https://data.tuik.gov. tr/Bulten/Index?p=Eld erly-Statistics-2020-37227 adresinden alınmıştır.

Akdemir, P., Görgülü, A., \& Çınar, F. İ. (2008). Yaşlı İstismarı ve İhmali. Sağlık Bilimleri Fakültesi Hemşirelik Dergisi, 68-75.

AKTAS POLAT, Y. (2015). TÜRKIYE'DE KENTSEL DÖNÜŞÜME BÜTÜNCÜL BİR BAKIŞ:Elazı̆̆ Örneği. Fırat Üniversitesi Sosyal Bilimler Dergisi, 25(1), 185-202.

ALVER, K. (2010, Aralık). Mahalle: Mekân ve Hayatın Esrarlı Birlikteliği. İdeal Kent(2), 116-139.

APK Daire Başkanlığı Araştırma Müdürlüğü. (2004). Sosyal Doku Projesi Araštırmaları - Yaşlılar. İstanbul: İstanbul Büyükşehir Belediyesi.

Arpacı, M. (2020). Pierre Bourdieu'nün Ssoyolojisinde Beden, Cinsiyet ve Cinsellik. İmgelem, 245-264.

Arş.gr.Samed KURBAN, Hatice AKMAN. (2019). Aynı Mekânda Ayrılıklar: David Harvey'İn Mekânsal Farklılaşma Kuramına Dair Bir Değerlendirme. Socia Sciences Studies Journal, 3266-3273.

Bilgili, M. (2016). Coğrafya Öğretiminde Mekân ve Yer Karmaşası Üzerine Bir Araştırma. Coğrafya Eğitimi Dergisi, 1119.

Böke, D. K. (Dü.). (2014). Sosyal Bilimlerde Araştırma Yöntemleri. İstanbul Alfa Yayınları.

Cem ERGUN, Ayșe DERICIIOĞULLARI ERGUN. (2010). Harvey'in Mekân Tartışmaları Ekseninde Yaşlıların Gözünden Kentsel Dönüșüm. Akademik Hassasiyetler, 121-145.
Ceylan, H. (2015). Yaşlılık ve Refah Devleti. İstanbul: Açılım Kitap.

Cicero. (2020). Yaşlı Cato veya Yaşlılık üzerine. (C. Çevik, Çev.) İstanbul: Türkiye İş Bankası Kültür Yayınları.

ÇAYIR, K. (2018). Ders Kitaplarında Yaşlılık Temsili. D. A. DUBEN içinde, Yaşlanma ve Yaşlılık (s. 79-95). İstanbul: İstanbul Bilgi Üniversitesi Yayınları.

ÇİTÇİ, Ü. (2019). Kent Mekânında Gündelik Yaşam Pratiklerini Etkileyen Sınır Tanımlayıcıların Betimlenmesine Yönelik Bir Deneme- Üsküdar Örneği. Fatih Sultan Mehmet Vakıf Üniversitesi Lisansüstü Eğitim Enstitüsü.

Dursun, O. (2018). Toplumu Pierre Bourdieu İle Düsünmek. Global Media Journal TR Edition, 68-123.

Dülgeroğlu- Yüksel, P., \& Kerem, D. (Dü). (1998). Göç, Kent ve Gecekondu. İstanbul: Birsen Yayınevi.

Ergun, C., \& Dericioğulları Ergun, A. (2020). Harvey'in Mekân Tartışmaları Ekseninde Yaşlıların Gözünden Kentsel Dönüşüm. Akademik Hassasiyetler, 121145.

Esendemir, S., \& Sağman, M. (2019). Yaşlanma Ve Mekân İlişkisi Üzerine: Türkiye'de Yaşlı Erkek Bireylerin Camii ve Kahvehane Kullanımlarının Analizi. Academic Review Of Humanities And Social Sciencs, 19-39.

GHULYAN, H. (Temmuz 2017). Lefebvre'nin Mekân Kuramının Yapısal ve Kavramsal Çerçevesine Dair Bir Okuma. Cağdaş Yerel Yönetimler Dergisi, 26(3), 1-29.

Görgün Baran, A., Günay, B., Bereketli, B., \& Işık, I. (2020). Sosyal Sermaye, Güven ve Yalnızlık Açısından Yaşlıların Yaşam Deneyimleri Üzerine Nitel Bir 
Yaşam Deneyimleri Üzerine Nitel Bir Araștırma. Yaşlı Sorunları Araştırma Dergisi, 72-89.

Gülhan, S. (2013). Özgürlüğün Coğraf yası: Mekânsallığın Triyalektik Praksisi ve Bütünsellik Arayışına Dair Bir Tahlil. Mülkiye Dergisi, 31-70.

Hastaoğlu, F. (2021). Yaşlıların Pandemi Sürecindeki Biyopsikososyal Etkilenimleri. YAŞLI SORUNLARI ARAŞTIRMA DERGİSİ, 45-49.

Hubbard, P., \& Kitchin, R. (2021) Mekân ve Yer Üzerine Büyük Düşünür ler. İstanbul: Litera Yayıncılık.

İstatistiklerle Yaşlılar, 2020. (tarih yok). Aralık 3, 2021 tarihinde Türkiye İstatistik Kurumu: https://data.tuik.gov.tr adresinden alındı

Kalaycı, A. R. (2011). Türkiye'de Yaşlılık Dönemine İlisskin Beklentiler. Anakara: T.C Aile Ve Sosyal Politikalar Bakanlığ Alile Toplum Hizmetleri Gene Müdürlüğü .

Kalınkara, V., \& Arpacı, F. (2013) Yerinde Yaşlanma. VII.Ulusal Yaşlılık Kongresi, 53-60.

Kaplan, M., \& Yardımcıoğlu, M. (2020). Alan, Habitus ve Sermaye Kavramlariyla Pierre Bourdieu. HABITUS Toplumbilim Dergisi, 23-37.

Kaya, E. (2007). Kentlessme ve Kentlileşme. Okutan Yayıncılık.

Kayacan, G. (2017). Modern Toplumlarda Yaşlılık, Ölüm Algısı Ve Yasçılık. MSGSÜ Sosyal Bilimler Dergisi, 15-29.

Kaygalak, İ. (2011). Postmodern Eleştirilerin Coğrafi Düșünce ve Yeni Mekân Kavrayısları Üzerine Yansımaları. Coğ rafi Bilimler Dergisi, 1-10.
KÜNTAY, E. (2014). Aile Desteğinden Devlet Desteğine Geçiș: Yatılı Bakım Kurumlarındaki Yaşlılar. Ö. A. Pınar AKKUS içinde, Sosyal Hizmet ve Öteki (s. 232-245). İstanbul: Bağlam Yayıncılık.

Lefebvre, H. (2015). Gündelik Hayatın Eleştirisi. İstanbul: Sel Yayıncılık.

Lefebvre, H. (2020). Şehir Hakkı. (I. Ergüden, Cev.) İstanbul: Sel Yayıncılık.

LOW, S. (2014). Placemaking and Embodied Space. A. Sen, \& L. SILVERMAN içinde, MAKING PLACE Space And Embodiment In The City (s. 19-44). Bloomington, Indiana: Indiana University Press.

Low, S. M. (2003). Embodied Space(s): Anthropological Theories of Body, Space, and Culture. Space and Culture, 9-18.

Marmara Üniversitesi Bilimsel Araştırma Projeleri Komisyon Başkanlığı. 2008). İstanbul'da Yasayan 65 Yas ve Üzeri Nüfusun Demografik, Ekonomik ve Sosyal Profili. İstanbul: İstanbul Büyükșehir Belediyesi.

Morley, D., \& Robins, K. (2011). Kimlik Mekânları. (E. Zeybekoğlu, Çev.) İstanbul: Ayrıntı Yayınları.

Murat ŞENTÜRK, Harun CEYLAN. (2015). İSTANBUL'DA YAŞLANMAK, İstanbul'da Yaşlıların Mevcut Durumu Araştırması. İstanbul: Açılım Kitap.

Özbay, F. (2014). Akrabalık ve Komşuluk İlişkileri. Boğaziçi Üniversitesi. Ankara: TC Aile ve Sosyal Politikalar Bakanlığı ve İPSOS.

Özbay, F. (2017). Dünden Bugüne Aile, Kent ve Nüfus. İstanbul: İletişim.

ÖZBEK, D. A. (2018). Beden Etkileșimli Mekân Tasarımı. The Turkish Online Journal of Design, Art and Communica- tion - TOJDAC, 133-142.

Özdemir, E. (2010, Mayıs). Kentin Tanımlanmasında Sosyolojik Yaklassımlar:Toplumsal Süreç ve/veya Mekânın Çözümlenmesi. Ideal Kent(1), 44-77.

Palabıyık, A. (2011). Pierre Bourdieu Sosyolojisinde "Habitus", "Sermaye" ve “Alan” Üzerine'. Liberal Düşünce, 121 141.

Poyraz, M. (2011). İstanbul Paris'in Yoksul Kenarları İle Merkez Arasındak Bağlar ve Kopma Noktaları. toplumbilim , 15-22.

Punch, K. F. (2011). Sosyal Arastırmalara Giriș. (D. Bayrak, H. Arslan, \& Z. Ak yüz, Çev.) Ankara: Siyasal Kitabevi.

Solak, Y. D. (2017). Mekân- Kimlik Etkilesimi: Kavramsal ve Kuramsal Bir Bakış. MANAS Sosyal Araştırmalar Dergisi, 13-37.

Soysal, A. G. (2020). Koronavirüs Salginı ve Yaslılık. Avrasya Sosyal ve Ekonomi Araştırmaları Dergisi, 290-301.

Şentürk, M., \& Kurtkapan, H. (2017) Yaşlılığın Mekânsallaşması: Kadıköy Moda'daki Bir Apartman Üzerine Nite Bir Çalışma. Yaşlılık Çalışmaları Dergisi, 4-19.

Sentürk, Ü. (2014). Mekân Sadece Mekân Değildir: Kentsel Mekânın Yen Tezahürleri. Doğu Batı, 85-106.

TEKELİ, İ. (2011). Kent, Kentli Hakları, Kentlesme ve Kentsel Dönüsüm. İstanbul: Tarih Vakfı Yurt Yayınları.

Tufan, İ. (2007). Birinci Türkiye Yaşl1lık Raporu. Antalya: GeroYay.

Türkiye İstatistik Kurumu. (2018, 5 16). İstatistikliklerle Genclik. 122018 19 tarihinde Türkiye İstatistik Kurumu
Haber Bülteni: http://www.tuik.gov.tr adresinden alınd

USTA, P. D. (2020). Mekân Ve Yer Kavramlarının Anlamsal Açıdan İrdelenemsi. The Turkish Online Journal of Design, Art and Communication, 25-30.

ÜSTÜN, E. (2015). Sinematografik Üretim: Mekân Ve Zaman Deneyiminin Bedenleşmesi. İTÜ Fen Bilimleri Enstitüsü Mimarlık Anabilim Dalı Mimari Tasarım Programı Yüksek Lisans Tezi. İstanbul.

Velittin KALINKARA, Fatma ARPACI. (2013). Yerinde Yaslanma. VII.Ulusal Yasl1lık Kongresi, (s. 54-60). Karabük

Vurmay, M. A. (2010). Edebiyat, Coğrafya ve Uzam: Hardy'nin Yuvaya Dönüş Adlı Romanı. Ankara Üniversitesi Dil ve Tarih-Coğrafya Fakültesi Dergisi, 207220.

Yaprak Akçakaya, E., \& Him, M. (2020). Yaşlıların Sosyal Ağlarının Afet Riski Bağlamında Değerlendirilmesi. Yaşlılık ve Calıșmaları Dergisi, 3-16.

Yarcı, S. (2011). Pierre Bourdieu'da Sosyal Sermaye Kavramı. Akademik İncelemeler Dergisi, 125-135.

YAVUZER, P. D. (2020). Mutlu Yaslanmak. İstanbul: Remzi Kitapevi.

Yazıcı, S. (2014). Gerontoloji ve Gelisim Süreci. N. Korkmaz, \& S. Yazıcı (Dü) içinde, Küreselleşme ve Yaşlılık (s. 2139). Ankara: Ütopya Yayınevi.

Zeybek, S. O. (2016). Ekolojinin politikası: Yeni sınırlar, Yeni aktörler. Toplum ve Bilim, 7-26. 


\section{Türkiye'de Tutunma Stratejisi Olarak Evlilik:}

Mülteci Evliliği

Kamer ÇAMURLUOĞLU1

\section{Özet}

Mülteci kadınları sığındıkları ülkelerdeki topluma ve toplumsal ilişkilere uyum süreçlerinin hangi dinamikler ile gerçekleştiğini Suriyeli mülteci kadınlarla görüşme yapılarak öğrenilmesi gerekmektedir. Bu araștırmanın temel problemini, Türkiye'de tutunma stratejisi olarak göçmen evliliğinin incelenmesidir. Araştırmanın temel problemi kapsamında Türkiye’ye göç eden Suriyeli kadınların hayata tutunma biçimleri incelenecek olup, bu tutunma stratejilerinden evliliği kullanıp kullanmadıkları tespit edilecektir. Bu araştırmada sosyal bilimler alanındaki bilimsel araştırmalarda sıklıkla tercih edilen bir yöntem olan nitel araştırma yöntemi kullanılmıștır. Verileri toplamakiçin araştırmacı tarafindan hazırlanmış yarıyapılandırılmış görüşme formu oluşturulmuştur. Görüşme formu toplam 19 sorudan oluşmaktadır. Bu çalışmada toplanan veriler içerik analizi yöntemi kullanılarak incelenmiștir. Araștırma sonuçlarına göre Türkiye'ye göç eden Suriyeli mülteci kadınlar buradaki hayata tutunma ve uyum sağlama konusunda evliliği tercih ettikleri sonucuna ulaşılmıştır. Mülakatlar sonrası mülteci kadınlar arasında evliliğin uyum ve tutunmayı kolaylastırdığı durumlar olmuştur. Ama evliliğin uyum ve tutunma konusunda pozitif bir etkisinin olmadığı durumlar da ortaya çıkmıștır. Bunun dıșında mülteci kadınlar evlilik yolunu tercih etseler bile sosyal anlamda dışlanmaya da maruz kalmaya devam etmektedirler.

\section{Anahtar Kelimeler}

Göç・Göçmen • Mülteci • Tutunma • Kadın

1 İstanbul Ticaret Üniversitesi, Sosyal Bilimler Enstitüsü, Uygulamalı Sosyoloji Bölümü Yüksek Lisans Öğrencisi, kamer4453@gmail.com, ORCID: 0000-0003-1478-518X

\begin{abstract}
Başvuru: 5 Ağustos 2021
Kabul: 30 Aralık 2021

kevizyon: 7 Eylül 2021

OnlineFirst: 31 Ocak 2022
\end{abstract}

Copyright $\odot 2021$ İnsan ve Medeniyet Hareketi http://toplumsaldegisim.com/ $20224(1)$ 56-69
Marriage as an Adaptation Strategy in Türkiye:

Refugee Marriage

Kamer ÇAMURLUOĞLU ${ }^{1}$
It is necessary to learn the dynamics of the adaptation processes of refugee women to the society and social relations in the countries where they take refuge by interviewing Syrian refugee women. The aim of the present study is to examine migrant marriage as an adaptation strategy in Türkiye. The adaptation way of Syrian women who have migrated to Türkiye will be analyzed within the scope of the main problem of the study. It will also be determined whether they used marriage as an adaptation strategy for this purpose. The qualitative method, which is frequently used in scientific research was used in the study. A semi-structured interview form was created by the researcher for data collection. The interview form is comprised of 19 questions. The collected data were analyzed using the content analysis method. According to the results of the study, it was concluded that Syrian refugee women who migrated to Türkiye prefer marriage in order to adapt and hold on to life here. There were cases where marriage facilitated the adaptation process among refugee women after the interviews. However, there have also been cases where the marriage did not have a positive effect on the adaptation process. Furthermore, even if refugee women prefer marriage, they continue to be exposed to social exclusion.

\section{Keywords}

Migration • Immigrant • Refugee • Hold • Woman 


\section{Giris}

2011 yılında Suriye'de ortaya çıkan halk ayaklanmaları sonrasinda Suriye re jiminin sert tutumu ve akabinde başlayan iç savaş, sivil halkın ülkeyi terk etmesin yol açmış ve savaşın şiddetinin artmasıy la birlikte milyonlarca Suriyeli Türkiye'ye göç etmeye bașlamıs ve Türkiye tarafinda "geçici koruma statüsü" ile kabul edilmi ve Türkiye'de yaşamaya başlamıștır(Adıgüzel ve Tanyaş, 2020). 2011'i takip eden yıllarda, Suriyeli mültecilerle ilgili yapılan araștırmalarda ciddi bir artışın olduğ görülmektedir. Bu çalışmalar arasında gö ve mültecilik, uyum, çatısma, is ve işsizlik, barınma, kadın göçmen, beslenme, hayatta kalma, baş etme gibi pek çok konunun literatürde yar aldığı görülmektedir. Özellikle 2018-2020 yılları arasında Suriye'dek çatışma ortamının üzerinden 7 yıl geçmi olmasına rağmen Türkiye'de yaşamın sürdüren Suriyeli ailelerin ve kadınların geliștirdikleri toplumsal ilişkilerin aile iş, çalışma, evlilik hayatı dahil oldukları bu yeni toplumsal sisteme tutunm konusunun anlaşılması önem arz etmeye başlamıştır. Türkiye'de yaşamını sürdüren Suriyeliler arasında önemli bir sayıda ye alan kadınların, Türkiye'de hangi koșulla ve dinamikler altında hayata tutunduk ları ve hangi sosyal dinamiklerle yașamlarını sürdürdüklerinin ortaya çıkarılmas ve anlaşılması hayati bir öneme sahiptir. Türkiye'de yaşamlarını sürdüren mülteci kadınların çok boyutlu sorunlarla baş etme biçimleri ve hayata tutunma stratejilerini ortaya koymak birlikte yaşamanın dinamiklerini de anlamamıza yardımc olacağı yadsınamayacak bir gerçek olarak durmaktadır (İncetahtac1, 2020; Deniz vd., 2016; Dizman, 2012; Şimşek, 2018 Harunoğulları ve Cengiz, 2016; Sirkeci ve Bardakçı, 2016).
Çatışma sebebiyle yerinden olup başka ülkeye göç etmenin erkekler ve kadınlar üzerindeki etkileri farklı olabilmektedir. Örneğin kadınlar göç sırasında ve sonrasında erkeklerden farklı olarak cinsel taciz ve istismara maruz kalabilmektedir. Bunun yanı sıra kadınların kiminle göç ettiği, göç sırasında yalnız olup olmadıkları, yanlarında çocuk, hasta veya yaşlıların bulunup bulunmadığı kadınların göç deneyimlerini önemli ölçüde farklılaştırdığı da önemli bir gerçektir (Buz, 2006; Almedom vd., 2005). Özellikle Çocuk sahibi olan kadınların göç deneyimlerinin daha fazla zorluklarla mücadele ile yaşandığı söylenebilir (Adıgüzel ve Tanyas, 2020). Cocuklu kadınlar, özellikle çocuklarının bakımı, eğitimi ve güvenliği ile ilgili durumlardan dolayı endișeler yaşamaktadırlar. Ayrıca uzun dönemli riskler ve psikolojik dayanıklılık açısından bakıldığında kadınların daha fazla risk altında oldukları görülmekte ve kadınların uzun vadede travma sonrası gelisim ve dönüsüme erkeklere oranla daha açık oldukları da tespit edilmiştir (Khattab ve Myrttinen, 2017; Adıgüzel ve Tanyaş, 2020). Örneğin Türkiye'deki Suriyeli mülteci kadınların ve kız çocuklarının aile içi siddet, zorla ve erken evlilikler gibi çeşitli şiddet türlerine maruz kaldıkları da tespit edilmiştir. Yine Türkiye'ye geldikten sonra, birçok mülteci kadının, erkeklerden cinsel içerikli teklifler aldıkları ve seks işçiliği yapmak zorunda bırakıldıkları da tespit edilmistir (Ördek, 2017; Healy, 2015; UNHCR ve ASAM, 2017; Adıgüzel ve Tanyaş, 2020).

Medyada nadiren yer alsa da Suriyeli kadınlar istismar, cinsel taciz, erken yaşta evlenme ve çok eşlilik gibi pek çok sorunla mücadele etmektedirler (Barın, 2015). Türkiye'de yaşayan Suriyeli kadın- lar Suriye'ye dönmemek için ya erken yaşta ya da ikinci eş olarak aileleri tarafindan evlendirilmektedir. Bu evliliklerin bir kısmı da resmi nikâh akdi yerine dini nikâh akdi gerçekleştirilmekte ve bu da toplumsal ve hukuki olarak sorunlara neden olmaktadır. Aileler bu evliiklerin gerçekleştirilmesinin en öneml sebeplerinin "kılarını korumak, yen edindikleri akrabalık bağları sayesinde kendi yașamlarını güvence altına almak ve ekonomik ihtiyaçlarını karşılamak" olarak gösterseler de bu tür evliliklerde kadınların terk edilmesi, ilk essin ve çocuklarının sömürüsüne uğraması gib durumlar düşünülmemiş ve kadınların istismara uğrama olasılıklarının artmasına neden olmuştur. Suriye'de olağan olarak kabul edilen hem erken yasta olan evlilik hem de çok eşli evlilikle Türkiye'de sadece Suriyeli ailelerin deği Türkiye'de var olan aile yapısını da olumsuz bir şekilde etkilemektedir. Ayrıca Suriyeli kadınların evlilikleri Türkiye'dek kadınlar arasında da ciddi kaygı durumu da yaratmaya başlamıștır (Barın, 2015; Kaya, 2015). Halihazırda ülkelerindek olumsuz şartlardan Türkiye'ye sığınan mülteci kadınların geride bıraktıklar olumsuz yaşamlarına ek olarak Türkiye'de onlarin hayata tutunmalarında hem bir seçenek hem de bir problem olan çok eşlilik ve kumalık durumlarıyla karşı karşıya kaldıkları da bilinmektedi (Çelik ve Vural, 2018). Evlilik modernlik öncesi toplumlardan günümüze kadar topluluklar arası iliskiler için önemli bi anlam ifade etmektedir. Günümüzde ise çeșitli sebeplerle mültecilik durumlarında da toplumda yer edinebilme ve göc edilen toplumda uyum içinde yalama ve hayata tutunmanın bassinda evlilik müessesi gelmektedir (Gültekin, 2018).
Bunun yanı sıra evlilik hem kadınlar için bir kurtuluş hem de aileleri için omuzlarındaki sorumluluğun ve ekonomik yükün hafiflemesi anlamına gelmektedir. Bu açıdan düşünüldüğünde savaş sürecinde hem Suriye'de yaşamaya devam etmek zorunda kalan aileler kızlarını komşu ülkelere evlenmeleri için göndermeye çalıșmakta hem de başka bir ülkeye göç eden aileler gittikleri ülkede tutunabilmek için kızlarını o ülkedeki insanlarla evlendirmektedir. Tüm bu evlilik süreçlerinde ise daha önce komşu ülkelere giden diğer Suriyeliler, özellikle de akrabaları, yardımcı olmaktadır (Özdemir ve Özdemir, 2018).

Suriyeli mülteci konusunda belki de üzerinde daha az durulan bir konu ise Suriyeli mültecilerin hayata tutunma çabalarıdır. Milyonlarca Suriyeli evini ve yurdunu terk edip, diline ve kültürüne yabancı olduğu bir ülkede ve çoğu kez “öteki” olarak görüldükleri bir düzlemde yaşadıkları travmaları geride bırakıp, sağlık, barınma, eğitim, temel hak ve özgürlüklerinin korunması vb. sorunlarla baş etmeye çalışarak, hayata tutunmak için çaba göstermektedir (Kizılkan, 2018). Hayata tutunmayı etkileyen önemli faktörlerden birisi ise dayanıklılık durumudur. Yapılan araştırmalar psikolojik dayanıklılığ yüksek olan göçmenlerin hayata tutunmalarının daha yukarıda olduğunu göstermiştir. Tutunmayı etkileyen dayanıklılığı genel olarak güçlükler karşssında olumlu adaptasyonun, diğer bir deyişle darbeler ve zorluklar karşısında yıkılmadan devam edebilme potansiyelini açığa çıkaran geniş bir kavram olarak tanımlanmaktadır (Masten ve Obradovic, 2006). Psikolojik dayanıklılık travma, yakın bir kişinin ölümü, hayati 
tehlike arz eden, potansiyel olarak rahat edici bir durum veya kayıp gibi stresli yaşam olaylarının aşırı yüküne rağmen hayatta kalma becerisidir (Agaibi ve Wilson, 2005; Bonanno, 2004). Psikolojik dayanıklılık, yaşanılan zorluğun daha iyi bir işlevselliğe yol açtığı zamanlard da bazen "travma sonrası gelişme" veya "güçlendirici etkiler" olarak adlandırılmaktadır (Rutter, 2008). Sığınmacılar ve mültecilerin tutunma ve dayanıklılık durumları incelendiğinde ise çok nadiren psikolojik dayanıklılıkları, tutunma yetenekleri ve sığınma talep ettikler topluma katkı sağlayacak kapasiteler olan insanlar olarak görülmektedirler. Bu kișiler daha ziyade muhtaç, çaresiz ve kaynakları sömüren kişiler olarak değerlendirilmektedirler (Grove ve Zwi, 2006). Psikolojik dayanıklılığın söz konusu olabilmesi için bireyin bir tehdide veya travmaya maruz kalması ve bu olumsuzluklara rağmen hayata tutunma sürecinde aksama yaşamamış olmas gerekmektedir. Başka bir deyişle bireyin gelişim sürecine veya göç sebebiyle git tiği yeni bir topluma uyumuna yönelik riskler bulunmasina rağmen oluml sonuçların ortaya çıkması söz konusu ise dayanıklılıktan bahsedilebilmektedir (Masten, 2001).

Özelde Suriyeliler olmak üzere Mülteci kadınlarla yapılan çalışmalarda bu kadınların gittikleri ülkede yaşadıklar sorunlar, o ülkede hayata tutunma biçimleri ve hayata tutunmak için kullandıkları stratejilerin arastırılmas mülteci kadınların yaşam kaliteleri için büyük bir önem arz etmektedir. Mülteci kadınları sığındıkları ülkelerdeki topluma ve toplumsal ilişkilere uyum süreçlerinin hangi dinamikler ile gerçeklestiğin Suriyeli mülteci kadınlarla görüşme yapılarak öğrenilmesi gerekmektedir. Bu arastırmanın temel problemini, Türkiye'de tutunma stratejisi olarak göçmen evliliğinin incelenmesidir. Araștırmanın temel problemi kapsaminda Türkiye'ye göç eden Suriyeli kadınların hayata tutunma biçimleri incelenecek olup, bu tutunma stratejilerinden evliliği kullanıp kullanmadıkları tespit edilecektir.

\section{Yöntem}

Türkiye'de tutunma stratejisi olarak göçmen evliliğinin incelendiğ $i$ bu araştırmada sosyal bilimler alanındaki bilimsel arasstırmalarda sıklıkla tercih edilen bir yöntem olan nitel araștırma yöntemi kullanılmıştır (Karasar, 2010).

\section{Evren ve Örneklem}

Araştırmanın evrenini Suriye'den Türkiye'ye sığınmış ve Türkiye'de evlilik yapmış Suriyeli göçmen kadınlar oluşturmaktadır. Araştırmanın örneklem grubu ise arastırmacı tarafindan kartopu örneklem yöntemiyle seçilmiş Türkiye'de evlilik yapmıș 15 Suriyeli kadından olusmaktadır. Örneklem grubunda yer alan kadınların yaşları 2449 yas arasında yer almaktadır. Mülakat yapılan Suriyeli kadınların Suriye'de doğum büyüdükleri yerler arasında ise Halep, Sam, İdlib gibi sehirler yer almaktadır. Ayrıca örneklem grubunun eğitim düzeyleri ise ilkokulu, ortaokulu, lise, üniversite terk ve üniversite düzeyindedir. Örneklem grubunda yer alan kadınlar çalıșmada "K" harfi ile kodlanmıștır. Suriyeli göçmen kadınlarla yapılan derinlemesine yapılan mülakatlar sonrası elde edilen bulgular açıklanırken de kadınlar yine $\mathrm{K}$ harfi ile anılacaktır. Karışıklık olmaması içinde mülakat yapılan kadınlar sirasiyla K1, K2, K3, K15 olarak numaralandırılmıştır.

\section{Veri Toplama Araçları}

Araștırmada kullanılacak veriler mülakat tekniği kullanılarak elde edilmiştir. Mülakat; iki ya da daha fazla kiş arasında belirli bir amaç etrafinda ve belli bir düzende yapılan soru-cevap şeklinde yapılan söyleşi tekniğidir olup sosyal bilimlerde yaygin olarak kullanılmaktadır (Coşkun, Altunışık ve Yıldırım. 2017). Mülakat tekniğinde yapılan görüssmelerde veriler toplanırken araştırmacı soruduğu sorulara görüşme yapılan kișilerden aldığı cevapları kaydederek konu hakkında detaylı bir şekilde alır. Bu tür görüşmelerde görüşülen kiş ile görüşmeci arasındaki diyaloglar ve kurulan ilişkiler görüşmenin güvenirliğ açısından son derece önemlidir. Araştırmacı görüşme esnasında hassas, özenli ve dikkatli olarak görüşmenin güvenirliliğini artırarak araștırma için doğru veriler elde edebilir (Kümbetoğlu, 2005).

Verileri toplamak için araştırmacı tarafından hazırlanmış yar yapılandırılmıs görüșme formu olușturulmuștur. Görüşme formu toplam 19 sorudan oluşmaktadır. Görüşme soruları arastırmanın amacina hizme edecek şekilde araştırmacı tarafindan konu ile ilgili ilgili literatür incelenerek gelistirilmistir. Hazırlanmıs olan görüsm formu 2 göçmen kadına uygulanarak görüssme sorularının anlaşılır ve açı sorulardan olușup oluşmadiğ 1 test edilmiștir. Yapılan örnek uygulamalar aracılığıyla görüssme formunda yer alan soruların göçmen mülteci kadınlar tarafından kolaylıkla anlaşıldığg ve cevap verildiği gözlemlenmiștir. Hazırlanan görüsme formunun, çalışmanın amacına ulaşmasın gerçekleştirmede yeterli ve geçerli olup olmadığının değerlendirilmesi amacıyl alan uzmanlarından görüssler alınmıştır.

\section{Verilerin Analizi}

Bu çalıșmada nitel araștırma yönemleri arasında yer alan içerik analizi kullanılmıştır. İçerik analizi, belirli kurallara dayalı kodlamalarla bir metnin bazı sözcüklerinin daha küçük içerik kategorileri ile özetlendiği sistematik, tekrarlanabilir bir tekniktir. İçerik analizinde temel amaç, toplanan verileri açıllayabilecek kavramlara ve iliskilere ulaşmaktır. Betimsel analizde özetlenen ve yorumlanan veriler, içerik analizinde daha derin bir ișleme tabi tutulur ve betimsel bir yaklaşımla fark edilemeyen kavram ve temalar bu analiz sonucu keşfedilebilir. Bu amaçla toplanan verilerin önce kavramsallaştırılması, daha onra da ortaya çkan kavramlara göre mantıklı bir biçimde düzenlenmesi ve buna göre veriyi açıklayan temaların saptanması gerekmektedir (Yıldırım ve Şimşek, 2005).

\section{Bulgular}

Bu bölümde araştırmanın bulguları mülakatlardan elde edilen veriler ışıda açıklanmıştır. Bulgular ele alınırken araştırmanın açıklık getiren mülakat soruları bulgu basslıkları olarak belirlenmiştir. Aşağıda yer alan her bir bulgu başlığı mülakatlardan elde edilen veriler, mülakatlardan alınan kanıt niteliğinde örnek cevaplar ışı̆̆ında çıklanmıștır. Mülakat yapılan mültecilerin Türkiye'deki evlilik süreçleri, Türkiye ve Suriye'deki evlilik arasındaki farklar hakkındaki fikirleri, evlilikten beklentileri, akrabalık ilişkileri, evlilik sonrası uyum süreci gibi durumları açıklanmıştır. 


\section{Mültecilerin Evlilik Süreçleri}

Görüşmelerden elde dilen verile 1şığında Suriye'den Türkiye'de göç eden mülteci kadınlar Suriye'deki savaş koşulları sebebiyle hayatta kalmak için göç et tiklerini belirtmişlerdir. Türkiye'ye gö ettikten sonra ise burada hayata tutunmak için evlilik yolunu tercih ettiklerin söylemişlerdir. Özellikle topluma uyumsuzluk, ekonomik gerekçeler, barınma sorunları, iş gibi sebepler mülteci kadınları Türkiye'deki yaşama tutunma konusunda evliliğe iten sebepler arasında yer almaktadır. Suriye'den Türkiye'ye göç sürecinde yanlarında hayata tutunma için temel ihtiyaçlarını bile karşılayabilecek maddi herhangi bir birikimler olmadan gelen kadınların hayata tutunmak için evlilik yolunu tercih etmeleri ise kaçınılmaz bir son olarak görünme ktedir. Ayrıca mülteci kadınların Suriye'den birlikte geldikleri diğer aile üyeleri ile aralarındaki problemli ilişkiler de mülteci kadınları evliliğe iten nedele arasında yer almaktadır. Mülteci kadınların evlilikle ilgili süreçlerinde evlilik fikirleri oluştuktan sonra evlenme şekli, evlenmenin resmi boyutu, ikinci es olup olmama durumları da bir açıdan rafa kalkmış görünmekte ve kadınlar tutunma için evlenmeyi düşündüklerinde evlenme sürecinin niteliğine odaklanmayıp hızlı bir evlilik süreçleri geçirmektedirler. Mülakat yapılan kadınlardan birisi K1 “... Ancak adam ikinci evliliğini yapacaktı ve bu durumun gizli kalmasını istiyordu. Ben de o zamanlar abimden çok fazla şiddet gördüğüm için 'kim olursa olsun evleneceğim' demiştim ..." diyerek hem hayata tutunma için evlilik yolunu tercih ettiğini belirtip hem de abisinden gördüğ̈̈ kötï şiddetten kurtulmak için gizli bir ikinci evliliği bile tercih edeceğini belirtmiştir. Aynı kadın bu evlilik gerçekleşmemesinin sonrasında yeğeninin çalıştığ iş yerinde çalışan birisi ile "Eşim, yeğenimle çalıştığ lokantadan tanışıyordu ve ona Suriyeli biriyle evlenmek istediğini söylemiş. Yeğenim de benim fotoğrafımı göstermiş o da kabul etmiş. Ben de onu gördüm ve beğendim. Sonrasında abimle konustum. Bilezik, elbise ve resmi nikah istiyorum bunu eşime ilet dedim ve resmi nikahla evlendik" sözleriyle evlendiğini belirtmiştir. Mülakat yapılan mülteci kadınlardan bazıları Türkiye'deki evliliklerini öncesinde başka bir evlilik geçirmiş olduklarını belirtirken bazıları da ilk evliliklerini Türkiye'de yaptıklarını söylemişlerdir. Mesela K3 “...Ben aslında evlilik düşünmüyordum. Suriye'de evlenmek hiç aklıma gelmezdi. Okul okuyordum ama evlilik istemiyordum. Ama buraya geldim para yok ev küçük kalabalık kendimi aileme yük gibi hissediyordum..." diyerek ilk defa evlendiğini ve bu evliliğini Türkiye’ye göc ettikten sonra hayata tutunma sebebiyle yaptığını belirtmiştir. Mülteci kadınlar bazıları evlendikleri erkeklerin ilk evlilikleri olduğunu söylemekle birlikte bazı kadınlar evlendikleri erkeklerin başlarından daha önce bir ya da daha fazla evlilik geçirdiklerini belirtmişlerdir. Örneğin K4 "Eşimle buradaki komşularım aracılığıyla tanıştım. İlk eşi ölmüş dört çocuğu olan bir adam var dediler evlenmek istersen görüş. Bende görüstüm imam nikahıyla evlendik." diyerek 4 çocuklu ve eşi vefat etmiş bir erkekle hem de dini nikah ile evlendiğini belirtmiştir. Türkiye de evlenen bazı mülteci kadınlar da Suriye'deki evliliğinin bittiğini (eşin vefatı sebebiyle) belirterek Türkiye'de göç ettikten sonra Suriyeli yetim çocuğu olan dul bir kadınla evlenmek isteyen bir erkekle evlendiğini söylemiștir. K2 “...Komșum olan bir abla bir gün bana biri var ama Türk ve orda evliymiş. Suriyeli yetimleri olan bir dul bayanla evlenmek istiyormuş dedi. Görüsstük ben olumlu bulunca abilerim İstanbul'da onlarla görüş onay verirlerse benim için tamam dedim...” Şimdiye kadar verilen örneklerde ve yapılan mülakatların çocuğunda mülteci kadınlar Türkiye'deki evlenme süreçlerine ya bir Türk ya da daha önce Türkiye'ye göç etmiş başka bir mülteci aracılığıyla evlenmişlerdir. Mülakat yapılan kadınlardan sadece birisi doğrudan evlendiğ erkekle tanışıp evlilik süreçlerini başlatmışlardır. K11 “...Türkiye'de yeniden sinava girdim. Kimya bölümünü kazandım. Orda bir yurda yerleștim. Orda okuyordum. Sonra bir sinav esnasinda eşimle tanıştık. Kimse aracı olmadı ve evlendik." diyerek herhangi bir arac olmadan bir eğitim süreci içerisinde eşiyle tanışıp evlenmiştir. Yapılan görüşm elerde her ne kadar Suriyeli mültec kadınlar mülteci olma durumunun getirmis olduğu dezavantajları ortadan kaldırmak ve hayata tutunmak için evliliği tercih etseler bile genel olarak evlilik ile ilgili teklif Türkiye'de yaşan erkek tarafindan yapılmaktadır. K14'ün de belirttiği gibi "Ben bir lokantada bulaşıç̧ılık yapıyordum eşim o lokantaya gelip gidiyordu müşteri olarak orda beni görmüş evlenmek istemiş." Suriyeli kadın evlenmeyi kabul ediyor olsa da evlenme yolunu açan kişinin Türkiye'de yaşayan erkek olduğu anlaşılmaktadır.

Yapılan mülakatlar sonucunda Suriye'den Türkiye'ye göç eden kadınların Türkiye'de uyum sorunlarını ve mülteci olmanın getirdiği dezavantajları ortadan kaldırmak amaçlı evlenmeyi tercih et- tikleri görülmektedir. Evlilik tercihi yapan Suriyeli kadınların her birinin birbirinden farklı evlilik süreçleri olmuştur. Dul olarak evlenme, dul ile evlenme, resmi nikahla evlenme, sadece dini nikahla evlenme, kuma olarak evlenme gibi farklı evlilik süreçleri ve hikayeleri olmuştur. Evlilikten beklentilerinin karşılanıp karşılanmadığı ve de evliliğin Türkiye'deki uyum süreçlerine ve hayata tutunmalarına katkı sağlayıp sağlamadığı ise sonraki başlıklarda açıklanmıştır.

Suriye ve Türkiye'deki Evliliklerin Karşıștırması

Yapılan mülakatlarda mülteci kadınların Suriye ve Türkiye'deki evlilikler ve her iki ülkedeki evlilikler arasındaki farklarla ilgili fikirleri alınmıştır. Mülteci kadınlar genele olarak Suriye'deki evliliklerdeki mehir olayının sıkı bir şekilde uygulandığını hatta mehri ödemeyen erkeklerin devlet tarafindan cezalandırıldığını söylediler. Görüşme yapilan kadınlardan K3 “...Suriye'de evlenen kadını devlet boşanırken imam nikahlı olsa bile koruyor. Mesela evlenmeden önce konuşulan mehrin bir kısmı düğünde takılan takılardan hariç kadına verilir ve geri kalan para verilmeden boşanma olmaz." diyerek kadınların en azından mehir konusunda devlet tarafindan korumaya alındığını ve bunun sıkı bir şekilde uygulanan kanun ve gelenek olduğunu belirtmişlerdir. Ayrıca mülteci kadınlardan bazıları Türkiye'de birden fazla kadınla (iki, üç ya da dört) evliliğin hoş karşılanmadığını ama bu durumun Suriye'de çok normal olduğunu belirttiler. K2 “Ama Suriye'de böyle bir şey yok. İkinci eşte normal ilk eş gibi evlenirdi düğün yapilırdı. Ama burada sadece dini nikah kıyılıyor düğün yapılmıyor.” Yine K2 “...Ben Türk bir eşle 
evlenince anladım Türk erkekler daha iyi daha az sinirliler bağırmıyorlar..." diyerek Suriye ve Türkiye arasindaki evlilik farkında erkek davranıssının farklı olduğunu belirtip Türkiye'deki erkeklerin daha nazik davrandıklarını belirtmiştir. Bunun aksi bir durumu da başka bi mülteci kadın belirtmiştir. K4 "Suriye'de kocalar karılarına çok kıymet veriyo ama burada öyle değil (șimdiki eșini eski eşi ile kıyaslıyor.) Eşi, her tartıştıklar zaman "Beğenmiyorsan git Halep'te kal" gibi bir açıllama ile Türkiye'de yapmıs olduğu evlilik deneyimi sonrasında Suriye'deki evliliklerde erkeklerin eşlerine kıymet verdiklerini belirtmiştir. Yine aynı mülteci kadın (K4) Türklerle iyi evlilik yapan Suriyeli arkadaşlarının da bulunduğunu belirterek diğer Türk erkeklerle yapılan evliliklerin kendi evliliğine göre daha iyi bir durumda olabileceğini açıklamıştır. Ayrıca K15 “Evlilikler bence millete göre değil kişilere ve ailelere göre değişir." gibi bir açıklama yaparak evliliklerin niteliğinin milletle arasındaki farklılıklara göre değil kiși, kişilik ve ailelere göre değișeceğini dile getirmiştir. Buna benzer bir açıllamay K1 “...Çok büyük bir fark yok...” diyerek yapmıştır. Bunların yanı sıra evlilik yaş ile ilgili bir farklılığı da K11 “.... Mesela Suriyeliler daha erken yaşta evlenirken Türkler daha geç yaşta evlilik yapıyorlar..." gibi bir ifade ile açıklamıştır.

Sonuç olarak Suriyeli mülteci kadınlarla yapılan görüşmelerde ortaya çıkan genel kanaate göre Suriye ve Türkiye'deki evliliklerle ilgili farklılıkların temelinde bazı ritüeller (mehir, nişan, düğün yapma) gibi farklılıklar, ikinci eș olm durumundaki farklılıkların yer aldığ sonucuna ulaşıllmıştır.

\section{Evlilikten Beklentiler ve Akrabalık}

\section{İlişkileri}

Suriyeli mülteci kadınlarla yapılan mülakatlar neticesinde kadınların Türkiye'de yapmış oldukları evliliklerdeki beklentiler ve bu evliliklerdeki aile ilişskilerine dair görüşler bu kısımda açıklanmıştır. Yapılan mülakatlar neticesinde genel olarak kadınların beklentileri arasında huzur, mutluluk, geçim sıkıntısının olmaması, değer verilmesi gibi beklentilerin olduğu sonucu ortaya çıkmıştır. Bu beklentilere örnek olarak K4 “...Her kadın gibi evlilikten beklentim sevmek, sevilmek, çocuklarıma değer verilmesi ve maddi olarak geçimimin sağlanmas1...”, K11 “...Evlilikten beklentim herkes gibi mutlu ve huzurlu bir hayat...” verilebilir. Mülakat yapılan kadınlardan birisi ise evlilik sürecinde hiçbir beklentisinin olmadığını sadece savaş sonrası ortaya çıkan sıkıntılardan bir an önce kurtulmak istediğini dile getirmiştir. Birçok görüşmeci de evlilikle ilgili beklentisini açıklamadan evliliğinin güzel olduğunu, beklentilerinin karşılandığını ve de mutlu bir evlilik hayatlarının olduğunu belirtmişlerdir. Bunlar arasında K6 “...Evlilik beklentimi karşıladı...”, K2 “...Evet eşim çok iyi bir insan onu seviyorum...” ve K9 “...Allaha şükür evliliğim çok iyi gidiyor. Eşim çok iyi bana karşı çok iyi davranıyor...” gibi açıklamalarla evlendikleri için mutlu olduklarını belirtmişlerdir. Evlilikle ilgili beklentilerin karşılandığının mülteci kadınlar tarafından yoğun bir şekilde dile getirilmesi evlilikten beklentilerinin az olduğundan kaynaklı olduğu düşünülebilir. Evlilikte doğal bir şekilde gelişen ve evliliğin sağlıklı bir şekilde ilerlemesini sağlayan akrabalık ilişkilerinde ise mülteci kadınlar genellikle olumsuz açıklamalarda bu- lundular. Mülteci kadınları çoğunluğu akrabalar tarafından dışlandığını, çok az görüştüklerini dile getirmişlerdir. Bunla arasında K2 “...ikinci eș olduğum için insanlar dışlıyor zaten yabancıyım bir de o var tabii...”, K3 “...Onlarla ben görüşüyordum ama onlar beni hiç istemediler. Çok az görüşmek istediler. Akrabalık ilişkileri kötüydü zaten. Sadece kız kardeşi ilgilendi benimle...”, K14 “...Hiç kimseyle görüşmüyorum. Onlarda beni arayıp sormuyor. Zaten onlarm benden haberler var $\mathrm{m} ı$ ondan bile emin değilim...” gibi açıklamalarla akrabalık ilişkilerinin zayıf olduğunu belirtmişlerdir. Bunların aksine K1'in açıkladığı gibi “.... Eşimin akrabalar ile aynı apartmanda oturuyorum. Aile apartmanındayız. Normal bir Türk gelin gibi eşimin akrabalarıyla görüșüyorum. Ben onlardan Türkçeyi öğreniyorum. İk çocuğum oldu. Kayınvalidem sürekli ben ziyaret eder ben de onları ziyaret ederim. Hiçbir sıkıntı yaşamadım..." açıklamasıyla iyi bir akrabalık ilişkisi olduğunu söyleyen mülteci kadınlar da bulunmuştur.

Görüssmelerden elde edilen veriler neticesinde Suriyeli mülteci kadınların evlilikle ilgili beklentilerinin düsük düzeyde olduğu bilgisine ulaşılmıştır Kadınların evlilikten beklentileri daha çok Maslow'un ihtiyaçlar hiyerarşisinin en alt basamağında yer alan fizyolojik ihtiyaçlar temelinde olduğu için genel olarak mülteci kadınların evlilikten memnun oldukları ve beklentilerinin karşılandığ sonucu ortaya çıkmıstır. Her ne kada evlilikten beklentiler karşlanıyor olsa da mülteci kadınlar akrabalık ilişkilerinin zayıf olmasından ve de akrabalar tarafindan dişlanmaktan şikayet etmek te ve bu durum karşısında üzüntülerini dile getirmektedirler. Mülteci kadının Türkiye'de uyum sürecini sadece bir evin içinde eşi ve çocuklarıyla zaman geçirerek elde edemeyeceği için akrabalık ilişkilerinin zayıf olması uyum sürecini olumsuz şekilde etkilemesi kaçınılmaz olarak karşımıza çıkmaktadır.

\section{Evlilik ve Uyum İlişkisi}

Yapılan mülakatlar neticesinde mülteci kadınların evlilik öncesi ve sonrasındaki uyum durumları ortaya çıkarılmıştır. Mülakat yapılan mülteci kadınların çoğunluğu Türkiye'deki hayata uyum konusunda sıkıntılar yaşadıklarının, evlilik sonrası da uyum sürecinin zorluklarının devam ettiğini belirtmişlerdir. Bu sıkıntıların temel sebebi ise Suriyeli oldukları için kendilerine ön yargı ile yaklaşıldığını belirterek açıklamışlardır. Az sayıda da olsa evlilik sonrası uyum sürecinde yaşadıkları zorlukları eşinin ve ailesinin desteği ile aştığını belirterek Türkiye’ye uyum sağladığını söylemiştir. Uyum konusunda ağırlıklı olarak olumsuz, az sayıda olumlu örnekler şöyledir: K2 “... Maalesef çok yaşıyorum insanlar soğuk davranıyor bana. Sokağa çıkmayı çok istemiyorum. Komşularım komşuluk yapmıyor Suriyeli olduğum için...”, K3 “...Burada insanlar kötü kötü bakıyor sokağa hiç çıkmak istemiyorum ben. Genelde evde kaliyorum...”, K11 “... Komşuluk ilişkilerim çok zayıf çok fazla insanla görüşemiyorum...”, K14 “...Uyum sorunu yaşıyorum, dil eksiğim var...”, K1 “...İlk başlarda çok fazla yaşadım çünkü dil bilmiyordum, kimseyle konuşamıyordum. Ve çalıştığım yerlerde patronlarım 14 saat çalıştırıp çok az maaş veriyordu. Calıstığım yerde insanlar hep kötü davranıyordu bana karşı. Ancak evlendikten sonra her şey değişti. Eşim ve ailesi bana sahip çıktı ben de zamanla buraya alışmaya ve sevmeye başladım...", K15 
“...Yeni geldiğimiz zaman yaşıyordum ama şimdi Türkçeyi öğrendim ve insanlar artık beni tanıdıkları için daha iyi davraniyorlar...”

Yukarıdaki örneklerde de görüldüğü gibi Suriyeli mülteci kadınların tamamı evlilik öncesi Türkiye'de uyum sağlama ve tutunma konusunda sorunlar yaşamıştır. Sorunlardan kurtulma, temel ihtiyaçları giderme, huzurlu bir yaşam sürme, uyum sağlama gib nedenlerle evlenen Suriyeli mültec kadınların önemli bir kısmı evlilik sonrasında da uyum sorunları yaşamaya de vam etmişlerdir. Bazı mülteci kadınlar ise evlilik sonra Türkiye'de yaşadıklar uyum sorunlarını atlatmış ve bu ülkedeki hayata daha kuvvetli bir şekilde tutunmaya başlamışlardır.

\section{Tartışma}

Arastırmadan elde edilen bulgulara göre Türkiye’ye göç eden Suriyeli mülteci kadınlar arasında bekar olanlar (daha önce hiç evlenmemis olanlar, daha önce evlilik geçmişi bulunanlar) buradaki hayata tutunma ve uyum sağlam konusunda evliliği tercih ettikleri sonucuna ulaşılmıştır. Mülakatlar sonrası mülteci kadınlar arasında evliliğin uyum ve tutunmayı kolaylaştırdığı durumlar olmuștur. Ama evliliğin uyum ve tutunma konusunda pozitif bir etkisinin olmadığı durumlar da ortaya çıkmıştır. Bunun dişında mülteci kadınlar evlilik yolunu tercih etseler bile sosyal anlamda dışlanmaya da maruz kalmaya devam etmektedirler.

Arastırmanın bulguları literatürdeki bazı çalışmalarla da desteklenmektedir. Bunlar arasında Gültekin (2018)'in çalısmasında evliliğin modernlik önces toplumlardan günümüze kadar toplu- luklar arası ilişkiler için önemli yeri olduğu söylenmekte ve günümüzde ise çeşitli sebeplerle mültecilik durumlarında da toplumda yer edinebilme ve göc edilen toplumda uyum içinde yaşama ve hayata tutunmanın başında evlilik müessesinin geldiği vurgulanmaktadır.

Ayrıca başka bir çalıșmada ise mülteci kadınların kamusal alana katılım konusunda daha fazla özgürlük deneyimledikleri için Türkiye'de edindikleri yeni rollerini güçlendirici olarak nitelendirmiștir. Araștırmada Suriyeli kadınların, Suriye'deki yaşamlarının büyük çoğunluğu için bir erkeğe bağımlı olduklarını bildirmișlerdir (Adıgüzel ve Tanyaş, 2020). Araştırmamızda elde edilen bulgularda ise kadınların Türkiye'deki hayata tutunmaları için bir erkeğe bağımlılık tercihini yaptıkları görülmektedir.

Başka bir çalıșmada ise çokeşlilik vurgusu yapılmaktadır. Ülkelerindeki olumsuz sartlardan Türkiye'ye sığınan mülteci kadınların geride bıraktıkları olumsuz yaşamlarına ek olarak Türkiye'de onların hayata tutunmalarında hem bir seçenek hem de bir problem olan çok eslilik ve kumalık durumlarıyla karşı karşıya kaldıkları da bilinmektedir (Çelik ve Vural, 2018). Bu çalışmadaki sonuc da arasstırmamızdaki bulgularda örtüşmekte ve mülakat yapılan kadınlardan bazılarının ikinci eş olarak evlilik yaptıkları bilgisine ulaşılmıştır.

Barın, (2015)'in çalıșmasında ise Suriye'de olağan olarak kabul edilen hem erken yașta olan evlilik hem de çok eșli evlilikler Türkiye'de sadece Suriyeli ailelerin değil Türkiye'de var olan aile yapısını da olumsuz bir sekilde etkilemektedir. Ayrıca Suriyeli kadınların evlilikleri Türkiye'deki kadınlar arasında da ciddi kaygi durumu da yaratmaya başlamıştır. Bu durum mülakat yapılan kadınlar tarafindan da belirtilmistir. Özellikle Suriye ve Türkiye'deki evlilik farkları açıklanırken mülteci kadınlar bu konuyla ilgili örnekler vermişlerdir. 


\section{Kaynakça}

Adıgüzel, S.Ö. ve Tanyaş, B. (2020) Suriyeli Mülteci Kadınların Göç Deneyimleri: Zorunlu Göç, Gündelik Yaşam ve Uyum Üzerine Nitel Bir Çalıșma. Kadem Kadın Araştırmaları Dergisi, Vol. 6, No. 2 173-210.

Agaibi, C.\&Wilson, C. (2005). Trauma, PTSD and resilience. Trauma, Violence and Abuse,6(3), 195-216. doi $10.1177 / 1524838005277438$.

Aldamen, Y. (2020). Sosyal Medyanın Ürdün ve Türkiye'de Yaşayan Suriyeli Mülteciler Üzerindeki Etkisi. Yayımlanmamıs Yüksek Lisans Tezi, Sosyal Bilimler Enstitüsü, İstanbul Üniversitesi, İstanbul.

Barın, H. (2015). Türkiye'deki Suriyeli Kadınların Toplumsal Bağlamd Yaşadıkları Sorunlar ve Çözüm Önerileri. Göç Araștırmaları Dergisi, 1(2), 10-56.

Bonanno, G. A. (2004). Loss, trauma and human resilience: have we underestimated the human capacity to thrive af ter extremely aversive events? American Psychologist, 59, 20-28.

Buz, S. (2006). Kadın ve Göç İlişkisi: Sığınan ve Sığınmacı Kadınlar Örneği Yayımlanmamıs Doktora Tezi, Sosyal Bilimler Enstitüsü, Hacettepe Üniversitesi, Ankara.

Celik, İ. A. ve Vural, F. (2018). Suriyeli Mülteci Kadınların Kuma Dramı: Kilis İlı Örneği, Uluslararası Toplum Araştırmaları Dergisi, 8(14).

Deniz, A. C., Ekinci, Y., ve Hülür, A. B. (2016). "Bizim Müstakbel Hep Harap Oldu” - Suriyeli Sığınmacıların Gündelik Hayat1 Antep - Kilis Cevresi. İstanbul: İstanbul Bilgi Üniversitesi Yayınları.
Dizman, A. O. (2012). Geçici Koruma Politikası ve Türkiye'ye Sığınan Suriyeliler. İstanbul: Türkiye Ekonomi Politikası Araştırma Vakfi (TEPAV).

Grove, N. J., \& Zwi, A. B. (2006). Our health and theirs: Forced migration, othering and Public health. Social Science \& Medicine, 62, 1931-1942.

Gültekin, M. N. (2018). Gaziantep’teki Suriyeli Mültecilerin Toplumsal Dayanışma ve

Etkileşim Noktaları, Turkish Studies Social Sciences, 13(26), 673-692.

Harunoğulları, M., ve Cengiz, D. (2016). Suriyeli Göçmenlerin Mekânsal Analizi: Hatay (Antakya) Örneği / Spatial analysis of Syrian immigrants: Case of Hatay (Antakya). Bilidiri,

TÜCAUM Uluslararası Coğrafya Sempozyumu / International Geography Symposium 13-14 Ekim 2016 /13-14 October 2016, Ankara

Healy, C. (2015). Targeting Vulnerabilities - The Impact of the Syrian War and Refugee Situation on Trafficking in Persons - A Study of Syria, Turkey, Lebanon, Jordan and Iraq. International Centre for Migration Policy Development. https:// d1r4g0yjvcc7lx.cloudfront.net//wpcontent/uploads/Targeting_Vulnerabilities_ EN_SOFT_-1.pdf

İncetahtac1, N. (2020). Gaziantep’te Suriyeli Ailelerin Baş etme Stratejileri. Gaziantep University Journal of Social Sciences, 19(2), 499-525.

Karasar, N. (2010). Bilimsel Araştırma Yöntemi. Ankara: Nobel Yayın Dağıtım.

Kaya, M. (2017). Türkiye’deki Suriyeliler: İc İçe Geçişler ve Karşılașmalar. İstanbul: Hiper Yayın.
Khattab, L. \& Myrttinen, H. (2017). "Most of the men want to leave" Armed groups, displacement and the gendered webs of vulnerability in Syria. International Alert. https://www.internationalalert.org/sites/default/files/Gender_VulnerabilitySyria_EN_2 017.pdf

Kizılkan, Z. B. (2018). Avrupa Birliğ ve Türkiye'nin Suriyeli Mültecilerin Dayanıklılığını Geliştirme Stratejileri, Mukaddime, Cilt 9 Sayı 3 - Özel Sayı, Avrupa Komşuluk Politikası ve Göç Özel Sayıs1, 95-114.

Kümbetoğlu, B. (2005). Sosyolojide ve Antropolojide Niteliksel Yöntem ve Araştırma. İstanbul: Bağlam Yayınları.

Masten, A. S. (2001). Resilience process in development. American Psychologist, 56(3), 227-238.

Masten, A. S. ve Obradovic, J. (2006) Competence and resilience in develop ment, New York Academy of Sciences, 1094 (1), 13-27.

Ördek, K. (2017). Syrians under "temporary protection" in Turkey and sex work. Red Umbrella Sexual Health and Human Rights Association. https://www. sexworkeurope.org/sites/default/files/userfiles/files/syrians\%20under\%20temporary.pdf

Özdemir, Ö. Ve Özdemir, E. (2018). Suriyeli Mülteci Kadınlar ve İnsani Güvenlik, Güvenlik Stratejileri Dergisi, 14 (27), 113-145

Rutter, M. (2008). Developing concepts in developmental psychopathology, Hudziak, J. J. (Ed.), Developmental psychopathology and wellness: Genetic and environmental influences içinde (ss. 3-22). Washington, DC: American Psychiatric Publishing.
Sirkeci, I., ve Bardakçı, S. (2016). Suriye'den Gelenler Misafir Değil Bir Göç Kültürünün Öncüleri. Humanitas Uluslararası Sosyal Bilimler Dergisi, 4(7), 531-544

Şimşek, D. (2018). Mülteci Entegrasyonu, Göç Politikaları ve Sosyal Sınıf: Türkiye'deki Suriyeli Mülteciler Örneği. Sosyal Politika Çalışmaları Dergisi, 18(40), 367-392.

UNHCR ve ASAM. (2017). Urban Refugee Women's Network - Turkey. In UNHCR. Gender Equality Promising Practices: Syrian Refugees in the Middle East and North Africa. UNHCR.

Yıldırım, A. ve Simsek, H. (2005). Nitel Araştırma Yöntemleri. Ankara: Seçkin Yayıncilık. 
1980 Sonrasi Küreselleşmenin Etkisi İle Güçlenen

Neoliberal Politikalarin Sosyal Devletin Rolüne Etkisi ve Küresel Sivil Toplumun Or taya Çıkışı

Merve Ege YANBASAR AKTAŞ ${ }^{1}$

Özet

Sivil toplum kavramı çok eski dönemlerde ortaya çıkmıș olmasına rağmen, küreselleşmenin etkisi ile 1980'li yılların sonlarında dünya gündemine gelmeye başlamıştır. Bu döneme kadar devlet denilince akla sosyal hayatı düzenleyen bir otorite gelmekteydi. Ancak zaman içerisinde yaşanan karmaşıklıklar ve ekonomik nedenler ile devletin toplumsal sorunları çözmede yetersiz kalması, küresel sivil toplum kavramını gündeme getirdi. Bu çalışmada sivil toplum ve devlet ilişkisini ele alırken öncelikle ilkel toplumların tarihsel süreç içerisinde belirli toplumsal hareketler ile siyasallaşarak devletin doğuşuna neden olması ve devlet kavramının gelişimini, buradan hareketle sivil toplum kavramının tarihini, liberal ve neoliberal politikalar etkisinde devletin sahip olduğu rolü, küreselleşme ile gelişen küresel sivil toplum kavramı bağlamında sivil toplum ile devletin göz ardı edilemez ilişkisini inceleyeceğiz. Çalışma sonucunda sivil toplum kavramının, sosyal hayatın düzenlenmesi, toplumsal sorunların ele alınması ve bu toplumsal sorunlara küresel boyutta çözüm aranması süreçlerinde devlet kavramının karşısında etkinliğinin arttığını göreceğiz.

\section{Anahtar Kelimeler}

Küreselleşme • Neoliberalizm • Sivil Toplum Kuruluşları

1 Marmara Üniversitesi- Sosyal Bilimler Enstitüsü/ Yönetişim ve Sivil Toplum Kuruluşları Yüksek Lisans Öğrencisi, merveyanbasar94@gmail.com, ORCID: 0000-0002-5116-5118

$\begin{array}{llr}\text { Bassvuru: } 20 \text { Ağustos 2021 } & \text { Kabul: } 30 \text { Aralık 2021 } & \text { Copyright } \odot \text { 2021 İnsan ve Medeniyet Hareketi } \\ \text { Illk Revizyon: } 17 \text { Eylü1 2021 } & \text { OnlineFirst: 31 Ocak 2022 } & \text { http://toplumsaldegisim.com/ } \\ \text { Son Revizyon: 29 Kasım 2021 } & & 2022 \text { 4(1) 70-87 }\end{array}$

OnlineFirst: 31 Ocak 202 $20224(1) 70-87$
The Effect of Neoliberal Policies Strengthened

by Globalization After 1980, on the Role of the Social State and the Emergence of Global Civil Society

Merve Ege YANBASAR AKTAȘ ${ }^{1}$

Although the concept of civil society originated in ancient times, it began to come to the world agenda in the late 1980s with the effect of globalization. Until this period, when the state was called, an authority that regulated social life came to mind. But over time, complexities and economic reasons, as well as the inability of the state to solve social problems, raised the concept of global civil society. In this study, we will first examine the relationship between civil society and the state in the context of the concept of global civil society, the history of the concept of civil society, the role of the state under the influence of liberal and neoliberal policies, the relationship between civil society and the state in the context of the concept of global civil society developing with globalization. As a result of the study, we will see that the concept of civil society increases its effectiveness in the face of the concept of the state in the processes of regulating social life, addressing social problems and looking for solutions to these social problems in a global dimension.

Keywords

Globalization • Neo Liberalism• Non-Governmental Organizations 
20. Yüzyılın sonuna damga vuran iki önemli kavram olarak sivil toplum ve küreselleşmeyi ele aldığımız bu çalışma, totaliter rejimlerin yıkılması sonucu ekonomik, siyasal, sosyal ve kültüre birçok alanda küreselleşme kavramının etkisiyle yeni bir boyut kazanan sivil toplum kavramı ve bu iki kavram arasındaki ilişkiyi incelemektedir. Sanayi Devrimi'nden önce tarım ve ticarete dayanan “dünya ekonomisi”, Sanayi Devrimi ile hızlı bir gelişim kazandı ve uluslararas alanda etkin bir yapı haline geldi. Bu süreç içerisinde kapitalist üretim modeli dünya ekonomilerinde hâkim konuma ulaştı. İkinci Dünya Savaşı sonrasında kurulan yeni düzen, sonrasında yaşanan Soğuk Savaş Dönemi ve liberal demokrasilerin varlığı, küreselleșmeye giden süreci hızlandırdı. Soğuk Savaş sonrası dönemde ulus devletler gelişen neoliberal politikaların da etkisiyle hem ekonomik alanda hem siyasi ve sosyal alanda etkilerini kaybetmeye başladılar. Teknolojik gelişmelerin de etkisi ile "ulus devletin bireyi” uluslararası bir aktör olma amacıyla ilgi alanlarını siyasal konular ve sorunları kapsayacak şekilde genişletmeye başladı. Yerelde özgürlük ve demokrasi kavramlarında yaşanan gelişmeler, küreselde sivil toplum kavramının yeniden canlanmasına neden olmuştur.

Çok eski dönemlerde ortaya çıkan sivil toplum kuruluşları, küreselleşmenin etkisi ile 1980 'lerde dünya gündemine oturdu. Sosyal hayatı düzenleme işlevine sahip olan devlet aktörü 19.yüzyılın ikinci yarısı itibariyle birçok alanda yetersiz kalmıştır. Bu durum devlet dışı aktör olarak sivil toplum kuruluşlarına olan ilgiyi arttırmıştır. Son elli yılın yükselen değeri olan sivil toplumun hem ulusal hem uluslararası alanda devletin yarattığı boşluğu doldurabilecek olduğu görülmüştür.

İkinci Dünya Savaşı sonrası dönemden 1970'li yıllara kadar olan süreç içerisinde devlet kavramını toplumsal kalkınma, refah ve yoksullukla mücadele gibi temel toplumsal sorunlarm çözümünde ilk yetkili ve sorumlu mercii olarak gören Keynesçi Refah Devleti ya da diğer bir deyişle Ulusal Kalkınmac1 Devlet modeli, 1980'li yıllar itibariyle terk edilmiş ve yerini devletin bu alanlardan piyasalar lehine çekilmesini esas alan neoliberal politikalara bırakmıştır (Bayraktar: 2017:108). 1990'lar yukarıda bahsettiğimiz alanlarda yaşanan ciddi krizler neticesinde Dünya Bankası da başta olmak üzere pek çok ulusal ve uluslararası kalkınma ve kredi kuruluşları, toplumsal sorunların belirlenmesi ve çözümü konularında STK'ları öncelikli ortak veya paydaş olarak tanımlamışlardır (Kamat, 2004: 166).

Bu makalede devlet kavramının ortaya çıkışından itibaren devlet ile sivil toplum ilişkisine değinirken son dönemde küreselleşme ve neoliberal politikaların devlet faktörü üzerindeki etkisi ve sivil toplum kavramının, devletin sosyal hayattaki yetersizliği ile güç kazanarak gündeme gelmesi sürecini ele alacağız.
Bu çerçevede öncelikle devlet kavramının ortaya çıkışı tarihsel bir arka planda sunulacak ve sonrasında devletin rolünü sivil toplum kuruluşlarına devretmesine neden olan küresel etkiler incelenecektir.

\section{Devlete Giden Süreç}

İlkel toplumlardan devlete giden süreçte, insan topluluklarının kırsaldan kent kültürüne geçişi bazı toplumsa olaylar sonucunda yaşanmıştır. İlkel dönemde göçebe bir hayat süren insan top lulukları zaman ile hayvancılık alanında çeşitli gelişmeler kaydetmiş ve besin üretiminin yani tarımın da yapılması ile küçük yerleşim birimlerinde yaşamların sürdürmüş ve köy, kasaba gibi yerleşim alanlarının ortaya çıkmasını sağlamıştır.

Zaman içerisinde nüfustaki artıs, kırsal alanda üretilen mal miktarının artması ile fazla malın ortaya çıkması ve bu üretimin pazarlanmasına duyulan ihtiyaç gibi etmenler ve gelişen toplumun yeni ihtiyaçlarının doğması sonucu, toplumu bir arada tutacak, birbirlerine zarar vermelerini engelleyecek siyasi bi varlığa yani devlete ihtiyaç duyulmuştur. Görüldüğü üzere ilkel toplumların tarihsel süreç içerisinde yaşadığı belirl toplumsal hareketler ile siyasallaşmasının sonucunda "devlet" adını verdiğimiz aktör doğmuştur.

\section{1. İlkel Toplum}

Günümüzde bilim insanları ve araştırmacılar tarafından insanlık tarihi "ilkel toplum ve uygar toplum" olarak ikiye ayrılmış ve ilkel topluluklar da "avcı toplayıcı ve besin üretici” topluluklar olarak sınıflandırılmaya tabi tutulmuştur (Şenel, 2009, sayfa. 134-136).

İlkel toplumların diğer canlılardan farklılaşarak toplum biçiminde ortaya çıkışı süreci, emek faktörünün kullanılması sonucunda yaşanmıștır (Sencer, 1987:33-34). Fransiz Antropolog Pierre Clastres ilkel toplum ve uygar toplum arasındaki ayrımı, devletsiz toplum ile devletli toplum arasındaki ayrım olarak değerlendirmenin gerekliliğini vurgulamıştır. Clastres'a göre ilkel toplumlar yani devletsiz toplumlar iktidar/devleti toplumu kaosa sürükleyebilecek olumsuz bir güç olarak nitelerken, uygar yani devletli toplumlar ise aksine iktidarl/ devleti kaosa son verebilecek olumlu bir güç olarak görmüştür.

Kabileler şeklinde hayatlarını devam ettiren ilkel toplumlar temel ihtiyaçlarını karşılama konusunda hayat tarzlarını "sürü halinde yaşayan topluluklar" olarak belirlemiştir. Sınırlı bir nüfus ile varlığını sürdüren ilkel toplumlarda "şeflik makamı" vardır ancak kabileler ayrı bir siyasal iktidarın ortaya çıkışını engellemektedir ve her zaman kabile şefin üzerindedir. İlkel toplum, toplumsal çatışmayı yasaklar, üretimin toplumu ezmesine izin vermez. Besin stoku toplumun ihtiyacı kadardır. Ancak ilkel toplumun ikinci evresi ile besin üretici topluluklar, toplumsal ihtiyaçtan fazlasını üretmeye başlamıştır.

İlkel toplum kendisini oluşturan her şeyin üzerinde "mutlak ve eksiksiz" bir 
güce sahiptir. Kendisini meydana getiren alt gruplara özerklik tanımaz.

2.1.1. Avcı ve Toplayıcı Topluluklar

Avc1-toplayıcı toplumları incelediğimizde tarihsel olarak yaklaşık 40.000 yll öncesine dayanan, yabani bitkiler ve hayvanları yiyerek yaşamlarını sürdüren, herhangi bir üretim yapmaksızın doğa ile uyumlu bir ilişki içerisinde yaşayan toplumları ele almaktayız.

En fazla yüz kişinin yaşadığ bu topluluklarda, üretim faaliyetlerinin yokluğundan kaynaklı olarak yöneten ve yönetilen ayrımı olmaksızın, ortak mülkiyetin varlığını ve buradan hareketle toplumsal eşitliğin söz konusu olduğunu görmekteyiz. Kısaca avc1-toplayıcı toplumlar arasında "eşitlikçi ve paylaşımcı" bir değer sisteminin hâkimiyetinden bahsederiz.

\subsubsection{Besin Üretici Topluluklar}

10-15.000 y1l öncesine dayanan besin üretici topluluklar, bitkisel ve hayvansal üretime geçiş yapıldığı dönemde cinsiyet ayrımına dayalı iş bölümü ile (basit iş bölümü) yaşamlarını sürdürmüşlerdir. Bu dönem ilkel toplumdan uygar topluma "geçiş dönemi" olarak da adlandırılmaktadır. Besin üretici topluluklarda insan, önce kendisi için üretim yapmıştır.

Sonrasında ihtiyacının fazlasını üretmeye başlamıs ve bu üretim fazlasının bölüşülmesi için örgütsel bir yapıya ihtiyaç duymuştur.

\section{2. İlkel Toplum ve Devletin Doğușu}

İlkel toplumlar zaman içerisinde belli aşamalardan geçerek siyasallaşmış ve modern anlamda devletin oluşumu evresinde önemli bir rol oynamışlardır. Avc1lık ve toplayıcılık ile "ihtiyaçları kadar" ilkesiyle yaşamlarını sürdüren, toplum içerisinde eşitsizliğin yer almadığı ve demokratik bir yapının söz konusu olduğu ilkel toplumlarda, kurulan bu düzen "savaşlar” nedeniyle bozulmaya başlamıştı. Bu toplumlarda "ferdiyet" sahibi olan tek tek üyeler değil bütün bir topluluktu, yani "klan"dı. Bunun bir sonucu olarak da sorumluluk kolektifti. Bu kolektif yapı hem fail hem de mağdur bakımındandı. Dolayısıyla iki ayrı topluluk fertlerinin birbirlerine verdiği zararlar mensubu bulundukları toplulukların savaşmasıyla sonuçlanırdı (Özcan, 2012: 285).

Düzensiz bir yaşam süren çoban toplulukları ve düzenli bir hayata sahip çiftçi toplulukları olarak iki gruba ayrılan bu topluluklar çoban topluluklarının, çiftçilerin üretimini ve süreç içerisinde değişen "ihtiyacı kadar" ilkesi yerine "afet durumları için üretim fazlası”nı yağmalaması ile toplumsal düzen değişmeye başladı. Toplumsal yapıdaki bu ikiliğin savaşa dönüşmesi sonucunda, çobanlar çiftçileri mağlup etti ve çiftçiler üzerinde bir otorite kurdular.

Ve devletin ortaya çıkışına zemin hazırladılar. Burada ilkel toplumdan modern devlete giden süreçte, devletin ortaya çıkışının temelinde aslında toplumun, birbirine sömürü ilişkisiyle bakan karşıt sınıflara bölünmüş olduğunu görmekteyiz.
Toplumsal çözülmeler sonucu yerleşik yaşam süren çiftçi topluluklarının elinde bulunan sulak bölgelere, tapınak lar kurulmuş ve üretim fazlası olarak adlandırılan toplumsal üretimin kaynağ olan suyun kontrolü tapınağın sahibine geçmiştir. Dinin kullanılması toplumsal baskı ile değil ikna yöntemi ile olmuştur. Üretim fazlasının tapınak adı verilen dini kurumlarda işlenmesi ve toplumu oluşturan çoban ve çiftçilerin dışında din adamları sınıfinın doğmasına neden olmuştur. Ekonomik, kültürel ve toplumsal işler din adamlarının yürüttükleri işler haline gelmiş ve böylece gerçekleşen kentleşme, din adamlarının bir yol çizmesi sonucu bir boyut kazanmıştır (Avc1, 2010). Devletli toplumu yaratmada öncü rol oynayan din adamları, topluma bu yeni sistemi kabul ettirirken politikalarını meşru bir zemine oturtmuş, "tanr1-devlet-kral” ilişkisini ilerleyen zamanlarda topluma işleyerek devletin toplum tarafından kabulünü sağlamışlardır.

Modern devletin temellerinin atıldığ bu dönemlerde toplumsal düzene karş yağma ve saldırıların başlaması sonucu ve kurulan yaşam alanlarının savunmas. ve korunması adına yeni bir toplumsal sınıf olan "asker sınıfı" ortaya çıkmıştır. Birlikte hareket etmeyi tercih eden asker sınıfi ve din adamları, toplumun ürettiği iktisadi fazlanın korunması ve ekonomik gelişimin sağlanması ile geniş topraklar üzerinde toplumsal üretimin artmasına katkıda bulunmuş ve ekonomik olarak güçlü kent devletlerinin ku- rulmasını kolaylaştırmışlardır. Ancak güçlü kent devletlerinin varlığı tarihsel süreç içerisinde savaşların tekrarlanmasına neden olmuştur.

Savaşların bu topluluklar için siyasi bir yöntem haline gelmesi ve din adamlarının savunma ve toplumsal kaynakların toplumsal üretim içerisine aktarılması süreçlerinde yetersiz kalması nedeniyle, siyasal erk asker sınıfının eline geçmiş ve krallıkların temeli atılmıştır (Avcı, 2010).

Göçebe olarak bir hayat süren Sümerler, Mezopotamya'da yerleşik yaşam süren topluluklar üzerinde kuvvet kullanması sonucu karşılıklı mücadeleler yaşanmış ve Mezopotamya'da egemenliklerini kurarak tarihte bilinen "ilk devlet" olarak ortaya çıkmıştır. Oppenheimer, “devletlerin doğuş nedeni, köylüler ile çobanlar, çalışanlar ile soyguncular, alçak vadilerdeki topraklarla yüksekteki yaylalar arasında yaşanan zıtlık" olduğunu söyler. Burada da gördüğümüz üzere toplumsal olarak ikiye ayrılan çiftçi ve çobanlar arasındaki mücadele sonucunda, günümüz modern devletinin temelleri atılmıştır. Askerin güç kazanması, din adamlarında güç kaybına neden olmuş ve yönetimde söz hakkı kalmayan din adamları sınıfinın görevi tanrı adına ülkeyi yöneten kişiyi onaylamak olmuştur.

Burada tarihsel süreç içerisinde ele aldığımız üzere askeri ve dini kurumlar üretime ortak olmuş ve zamanla toplumsal baskı unsuru olarak "iktidar kurumları" konumuna gelmiş ve devleti oluşturmuşlardır. 


\subsection{Uygar Toplum}

İlkel toplumdan devlete geçiş tarihsel olarak uzun bir süreci kapsamaktadır. Belirli aşamalardan geçen ilkel toplum, bu tarihsel süreç içerisinde kendisine has özellikler oluşturmuş ve toplumsal olaylar ile değişime uğrayan bu özellikler zaman ile ilkel toplumdan "uygar toplum" aşamasına geçilmesine vesile olmuştur. İlkel toplumun en temel özelliği dendiği zaman akla ilk olarak "devletsiz” olmaları gelmektedir. Toplumsal eşitliğin söz konusu olduğu ilkel toplumda toplumsal ayrışmaya neden olan yöneten-yönetilen sınıfları bulunmamaktadır. İlkel toplumda devlet aygıtının büyüyüp gelişmesinin imkânı yoktur. Kisacası ilkel olmayan her toplum esasında devletli toplum olacaktır (Clastres, 2016:188).

M.Ö. 4000li yıllarda insanın, uygar topluma geçişinin ilk örneği olarak "Sümerler” adı verilen topluluk, Aşağı Mezopotamya bölgesine yerleşmiş ve bu durum yirminci yüzyılın başlarında yapılan araştırmalarla kesinliğe ulaşmıştır (Şenel, 2014:357). M.Ö. 3500lerde köyler kent haline gelmeye başlamış ve M.Ö. 3000li y1llarda ise Mezopotamya'da ilk şehir devletleri kurulmaya başlanmıştır.

Şenel'e göre "Uygar topluma geçiş ile devlete geçiş birbirinden ayırt edilemeyecek iç içe süreçler" olarak görülmektedir (Şenel, 2009, s. 327).

\subsection{Eşit Toplumdan Sınıflı Topluma}

İlkel toplumdan Uygar topluma geçişte kabileler şeklinde yaşayan insanların, tarımı keşfetmesi üretim faaliyetlerinin başlaması, avcılık ve toplayıcılıktan kurtulup, yerleşik kültüre geçmelerine sebep olmuştur. Kabileler konar göçer yaşamı bırakıp köy yaşam tarzını seçmiş ancak tarımsal üretim hala ihtiyaç kadar yapıldığı için fazla üretime geçilememiştir ve "toplumsal eşitlikçi” yapı devam etmektedir.

Hayvancılık faaliyetlerindeki gelişmelerle birlikte insanlar tarımsal faaliyetlerde çeşitli aletleri kullanmaya başlamış bu durum daha kısa sürede daha fazla üretimin yapılmasına ve "üretim fazlası"nın ortaya çıkmasına neden olmuştur ve üretim fazlasına sahip olacak kişinin kim olacağı sorusu ortaya çıkmıştır.

Bu soru tarihsel süreç içerisinde cevap bulmuştur. Sulak alanların ele geçirilmesi ve kabile içinde öncü olan birtakım insanlar tarafindan bu alanlara el konulması, özel mülkiyetin doğuşuna, bu da sınıflı toplum yapısının oluşmasına neden olmustur.

\subsection{Devlete Giden Süreç}

Hızla artan nüfus ve yeni üretim teknikleri ile beraber küçük yerleşim alanı olan köylerin yerini büyük köyler aldı ve kabileler arası çatışmalar yaşanmaya başladı. Diğer kabilelerin saldırısından korunmak için köylere koruma duvarları örüldü ve yavaş yavaş kentleşme adımları atıldı. Bütün bu sınıfsal mücadele- ler, özel mülkiyet kavramının gelişmesi ve üretim ilişkileri konularında, insanın insanla olan ilişkilerini düzenlemek amacıyla, hukuk kavramının ortaya çıkmasına neden oldu. Ve tüm bu süreçlerde askeri sınıf, hukuk düzeninin koruyucusu ve yaptırım gücü oldu.

Üretim ile gelişen ticaret, asker sınıfi, hukuk düzeni gibi kavramlar devlet aktörünün doğuşu anlamına geliyordu. Dünyada bu gelişmeler yaşanırken toplumda sınıf mücadeleleri baş gösterdi, hâkim sınıf olma yani yöneten sınıfi olma ve hâkim sınıf olamama yani yönetilen sinıf olma mücadeleleri günümüze kadar sürecek sınıfsal çatışmaların temeliydi. Sınıfların bu iktidar mücadelesini devletin kendisi olma/devlet olma mücadelesi olarak adlandırabiliriz.

3.1.1980 Öncesi Sosyal Devlet Kavramı

Tarih boyunca yaşanan çeşitli toplumsal olayların ardından devlet kavramının önemi ve rolü zaman içerisinde değişmiştir. "Refah devleti ya da sosyal devlet” kavramı zamana ve ülkelere göre farklı şekillerde tanımlanmıştır. 19. Yüzyıl sonlarında ortaya çıkan sosyal devlet, toplumun sosyal refahını en üst düzeye çıkarmak amacıyla, toplumsal müdahalelerde bulunun bir devlet modelidir. Kriz, savaş, çatışma gibi toplumsal olayların yaşandığ 1 dönemlerin sonrasında devlet hem sosyal yaşama hem de ekonomik yaşama çeşitli müdahalelerde bulunarak, yaşanan toplumsal olaylar sonucunda meydana gelen yoksulluk, toplumsal adaletsizlik, gelir dağılımın- da ortaya çıkan sorunlar ve toplumun refahını etkileyen olaylarla mücadele konusunda çeşitli roller üstlenmiştir.

\section{Sosyal devlet;}

- Müdahaleci bir devlet anlayışıdır.

- Düzenleyici bir devlet anlayışıdır.

- Yeniden dağıtıcı bir devlet anlayışıdır.

- Girişimci bir devlet anlayışıdır

- Bireylere hak ve özgürlüklerin sağlanması bakımından pozitif bir devlet anlayışıdır. (Aktan, 1995: 73-74)

Liberal ekonomiyi benimseyen ülkelerde gelir dağılımında yaşanan dengesizlik sonucu devletin piyasaya müdahalede bulunmuş ve toplumsal sorunlara çözüm arama kapsamında "sosyal devlet" kavramı ortaya atılmıştır. Sosyal devletin amacı, bireylerin refah düzeyinin eşitlenmesinden ziyade, devlet müdahalesi ile topluma karşı çeşitli sorumluluklar üstlenerek bireylerin temel ihtiyaçları çerçevesinde "işsizlik sigortası, sağlık sigortas1, ücretsiz eğitim, aile ve çocuk yardımı ve uygun fiyatlı konut sağlama gibi uygulamalar" ile bu eşitsizliklerin toplumsal hayatı engellemesinin önüne geçmektir.

19. yüzyılın sonu itibariyle kapitalist devlet anlayışındaki değişiklikler sonucu liberalizm ve sosyalizm etkisiyle ortaya çıkan sosyal devlet modeli, ortaya atıldığı dönemde dünyanın gündemine oturmuştur. Sosyal devlet olma hedefine dönük ilk adımlar Almanya tarafindan atılmıştır. İstatistiki veriler ele alındı- 
ğında, Almanya'nın sosyal devletin öncüsü olduğu görülmektedir. İş kazası sigortası (1871), sağlık sigortası (1883) ve emekli maaşı (1889) gibi sosyal devle uygulamaları ilk kez bu ülkede hayata geçirilmiştir (Aktan, 2008).

20. yüzyıla gelindiğinde 29 krizi ve reel sosyalizm deneyimleri refah devleti modeline geçişin ortaya çıkmasını sağlamıştır (http://www.sosyalhizmetuzmani. org/stk_devlet.htm). Sosyal devlet modelinin uygulanması ile toplumda sivillik kavramı, bireysel özgürlükler, örgüt kurma, katılımcı demokrasi anlayışı, sivil ve demokratik toplum gibi kavramlar öne çıkmıştır. Modern sivil toplum kavramı bu konjonktür bağlamında tarihsel süreç içerisinde şekillenmiştir. Liberal politikaların uygulanması sebebiyle sosyal devlet modelinde siyaset üretmek yalnızca siyasi partilere indirgenmemiştir ayn zamanda sivil toplumun da bir özelliğ olarak ele alınmıştır. Bu durum refah devletinde sivil toplum kavramının güçlenmesine ve hem kamusal alanda hem de siyasi alanda sivil toplumun bir aktör olarak rol oynamasına neden olmuştur.

1950’lerde birçok ülke için itibar kazandıran sosyal devlet modelinin çöküşü, 1970'li yıllarda başlamıştır. Sosyal devlet modeline karşı güçlenen siyasi akım "neoliberalizm" olmuştur. Sosyal devlet modelinin güç kaybetmesinin en büyük sebebi olarak, devletin sosyal harcamaların altında ezilmesi ve yaşanan toplumsal problemlere çözüm arama boyutunda yetersiz kalması gösterilir.

\subsection{Sonrası Neo liberal Politi-} kalar

1980'li yıllardan itibaren sosyal devlet modeline karşı yapılan eleştiriler artmıştır. Neoliberal politikanın güç kazanması ve küreselleşmenin etkisi ile devlet kavramı yeniden yapılandırılmış ve bu yapılandırma çerçevesinde yeniden tanımlanmıștır. Bu doğrultuda sosyal devlet modelinin yerini, birçok ülkede neoliberal devlet modeli almaktadır.

1980 öncesi liberal ekonomi politikalarının neden olduğu toplumsal sosyal eşitsizliklerin giderilmesi ve bu amaçla insanlara asgari bir yaşam düzeyinin sağlanması niyetiyle hareket eden sosyal devlet sistemi, kapitalist düşünce sistemini ortadan kaldıramamıștır. Sosyal devlet modeli içerisinde kamu iktisadi kuruluşları, kamu hizmetlerinin yerine getirilmesi hususunda küresel rekabet ortamında başarılı olamamış ve bu başarısızlık ekonomiye ağır bir yük olarak yansımıştır. Küreselleşme süreci içerisinde tüm ülkeler tarafindan bu ekonomik yükler hissedilmiş ve bu durum dünya genelinde sosyal devlet modelinden uzaklaşılmasına neden olmuştur (Ertuğrul, 2004).

Küreselleşme süreci ile ekonomik ilkeler uluslararası sermaye tarafindan belirlenir hale gelmiştir ve bu rekabet ortamına giren devletler belirlenen ilkeler çerçevesinde hareket etmeye zorlanmıştır. Ve uzun süre dünya gündemini meşgul eden bir model olan refah devleti modeli yerini ve rolünü neoliberal devlete devretmiştir. Neo-liberal anlayış, özgür ve adil bir toplumun ancak Pazar mekanizması tarafından kendiliğinden oluşan bir düzenle var olabileceğini iler sürer (Ertuğrul- Çolak, 2010).

ABD ve İngiltere tarafindan 1980'li yıllarda devletin küçülmesinin gerekliliği vurgulanmıştır. Kamunun müdahalesinin gerekliliğini savunan Keynezyen politikanın aksine "başka alternatif yok" söylemiyle ortaya çıkan neoliberal yaklaşım, mükemmel piyasa için devletin piyasadaki rolünün küçülmesi gerektiğin savunmuş ve bu sebeple piyasa ekonomisinin gücü artmıştır. Bu bağlamda kamu harcamaları azaltılmıștır. Neo liberal politikalar ile ülkelerin kalkınma performansı ve halkların yaşam standardı yükselmiş, yönetimde demokrasi ve şeffaflık teşvik edilmiştir.

\subsection{Neoliberal Politikaların Sosyal}

\section{Devlete Etkisi}

Neoliberal politikaların etkisiyle güçlenen küreselleşme kavramı, yalnızca ekonomik alanda değil aynı zamanda kitle iletişim araçlarının kullanımının yaygınlaşması ile siyasal, sosyal ve kültürel birçok alanda etkili olmuştur. Sovyet bloğunun yıkılışı ve küreselleşme ile sosyal devlet, işlevini yerine getirme konusunda sıkıntılar yaşarken bu süreçte piyasa ekonomisi yükselişe geçmiş ve sivil toplum kavramı yeniden bir dirilis yaşamıştır.

Refah devletinde yaşanan sosyo-ekonomik krizler, sosyal devletin eşitlik, adalet, temel hak ve özgürlükler ile ilgili toplumsal sorunların çözümünde yetersiz kalmasının ardından Batı'nın post modernizasyon süreci ve neoliberal politikaları ile şekillenen küreselleşme olgularıyla, sivil toplum kavramı yeniden üretilmiştir. Liberal sosyal devlet modelinde, devletin kalkınma aracı haline gelen sivil toplum zaman içerisinde devletin rolünü üstlenmiş ve devletin sosyal alandaki etkisi azalmıștır.

\section{KÜRESEL SIVIIL TOPLUM}

\subsection{Sivil Toplum-Politik Toplum}

Sivil toplum-politik toplum ayrımını yaparken politik toplumu "devlet" olarak ele alıp sivil toplumu "doğrudan doğruya devletin denetiminde olmayan bütün alanlar" olarak ele almaktayız.

\subsection{Sivil Toplum Kavramina Tarihsel} Bir Bakış

Ilkel toplumdan uygar topluma geçildiği dönemde özellikle Orta Çağ döneminde merkezi krallıklar kurulmaya başlanmıştır. 16 ve 17.yüzyıllarda krallar sahip oldukları orduların ihtiyaçlarını karşılamak üzere o dönemde nakit parayı ellerinde bulunduran tüccarlara ve burjuva sınıfina danışmışlardır ancak bu sınıflar nakdi paranın karşılığında kraldan, çıkarları doğrultusunda bazı haklar talep etmişlerdir: "Yaşadıkları kentlerde kendi kararlarına kendilerinin karar vermesi yani kralın hiçbir şekilde o kentin iç işlerine karışmaması" gibi haklar vesilesi ile kentler, dönemin özerk alanları olmuş ve sivil toplumun ilk adımları atılmıştır. 
Tüm bu yaşanan tarihsel olaylar sonucunda, bugün sivil toplum kavramının ilk ortaya çıkışı hakkında konuşurken, aristokrasiye karşı mücadele ederek bazı haklara sahip olan burjuvaları ele alıyoruz.

Tarih sahnesinde sivil toplum kavraminı ilk kez Aristo ve Platon tarafindan kullanılmıştır ve bu kavramın, dönemin polis devletleri üzerinden ortaya çıktığı söylenmektedir. Antik Yunanda polis alanı "özgür yurttaşların devlet yönetimine katıldıkları, yaşam için gerekli zorunluluklardan uzak, insani varoluşun gerçekleştirildiği "bir alan olarak tanımlanmıştır. (Arendt, 1996: 34). Aristo tarafindan ortaya atılan ve Çiçero tarafından 1438 yılında Latinceye çevrilen "societas civilis” yani Politike Koinonia kavramı, sivil toplum kavramının tarihsel kullanımı konusunda başlangıç olarak sayılmaktadır. Ancak bu kavram zaman içerisinde bazı değişikliklere uğramıştır. Devlet üçüncü bir şahıs gibi algılanarak sivil toplum-politik toplum ikiliğinin doğmasına ve sonrasında Hegel, Gramsci ve Marx tarafindan "devlet ile beraber" tanımlanan sivil toplum, "devlete göre” tanımlanmaya başlanmıştır. Aile, devlet ve sivil toplumu birbirinden tamamen ayıran Hegel, sivil toplum kavramını tanımlarken karışık/kompleks bir sosyal düzenin teorisi olarak ele almıştır.

1980 sonrasinda sivil toplum Bat kavramı olmaktan çıkarak küresel bir kavram haline gelmiştir ve 1990 ile beraber "çağdaş sivil toplum" kavramı literatüre hâkim olmaya başlamıştır.
Günümüzde ise sivil toplumu toplumsal sorunları ele alan ve bu sorunlara devlet otoritesinin dişında çözüm arayan, devlet otoritesi dışında hareket etme alışkanlığ1 edinmiş, devlete düşman olmayan ancak devletten bağımsız olan toplum olarak tanımlamaktayız. Sivil toplumun bir sözleşme ile "oluşturulmuş” olmayıp, doğal bir süreç içerisinde şekillen bir kurum olduğunu belirten ve onu ahlaki bir kategori olarak değerlendiren Ferguson, sivil toplumun bir medeniyet ve bir ilişkiler bütünü olduğunu vurgular (Tester,1992: 46).

Çağdaş sivil toplum kavramı kamusal hizmetlerin yerine getirilmesi ve demokrasinin işler halde olması bağlamında tanımlanmaktadır. Sivil toplumun varlığından söz edebilmemiz için bireylerin haklara sahip olması ve dokunulmazlıklarının bulunması, toplum içerisinde gönüllü örgütlenmelerin varlığ gerekmektedir. Gramsci sivil toplumdaki bireyi politik mücadelenin aktörü olarak tanımlamaktadır. Bu birey haklara sahiptir ve toplumsal sorunlara çözüm olarak örgütlü hareket eder ve ortak hizmetlerin yerine getirilmesini sağlar. Ancak sivil toplumun belirlenen amaca ulaşabilmesi ve katılımcı demokrasinin sağlanması için, gönüllülük esasıyla örgütlenen bireylerin, kamusal sorunlara ve çözümlerine ilişkin hareket edebilmeleri, sahip oldukları temel hakların ve özgürlüklerin anayasal çerçevede tanımlanmış ve korunmuş olması gerekmektedir.

\subsection{Politik Toplum}

Batı toplumlarında sivil toplum-politik toplum ayrımı Anglo-Sakson mode ve Fransız Modeli üzerinden tanımlanmaktadır. İngiltere ve Amerika'da uygulanan Anglo-Sakson modelde toplum yukarıdan-aşağıya şekillenmez, yani toplumu şekillendiren devlet değildir bireydir. Fransa modelinde ise toplum yukarıdan-aşağıya şekillenmektedir yani toplumun şekillenmesinde rol oynayan aktör devlettir. Günümüz sivil toplum-politik toplum ilişkileri bu anlayışlar çerçevesinde biçimlenmiş ve tanımlanmıştır (Hira-Şan 2009).

Sivil toplum kavramını ilk kez eserinde başlık olarak kullanan (Doğan, 2002:71) Ferguson'a göre, despotizme bürünen politik toplum (devlet), bireyleri pasifleştirir, vatandaşları kendi haklarından mahrum bırakır ve bunu sağlamak için de geniş bir bürokratik düzenden yararlanır. Korku, güç ve militarizmi kullanarak kamusal alan üzerindeki her çeşit tartışmayı engelleyerek tekil kamusallığa neden olur (Ylldırım, 2005:63).

\subsection{Gönüllüilülk Kavramı}

Gönüllülük kavramı, kişiden kişiye toplumdan topluma değişse de özünde bireyin özgür iradesi ile bir toplumsal girişim ya da sivil hareket aracılığıyla, içinde yaşadığı topluma, sosyal hizmetlerin ulaşması amacıyla eyleme geçirdiği faaliyetlerin bütününü ifade etmektedir

Gönüllü katılım ise, en genis anlamıyla, toplum yaşamını etkilemek amaciyla girişilen bireysel ya da toplu hareketler olarak tanımlanmaktadır (Cooper, 2006:76).

Gönüllü katılımın sahip olduğu bazı özellikler vardır. Bunlar: zorunlu olmaması (gönüllü olması), karşılık beklenmeksizin yapılması ve kamu yararı amacına gütmesidir.

Gönüllülük kavramının dünya çapında farkındalık kazanması 1985 yılı itibariyle Birleşmiş Milletler Genel Kurulu'nun 5 Aralık tarihini "Dünya Gönüllüler Günü” olarak kutlamasıyla birlikte olmuştur. Ve gönüllü hizmetlerinin yaygınlaştırılması adına 2001 yılı "Dünya Gönüllüler Yılı” olarak ilan edilmiş ve sonrasında birçok ülke bu çalışmaya destek sağlamıștır. Bugün Türkiye'nin de aralarında bulunduğu 123 ülkede 5 Aralık tarihi Gönüllüler Günü olarak kutlanmaktadır ve birçok kurum ve kuruluş her sene yaptığı çalışmalar ve projeler içerisine gönüllü çalışmaları dahil eder bir konuma gelmiştir.

\subsection{Küreselleşen Dünyada Gönüllülük}

En basit haliyle "küreselleşme" uzak-yakın kavramının göz ardı edilerek insanların ve ülkelerin birbirine gerek ekonomik gerekse sosyal etkileşim konusunda yakınlaşması olarak tanımlanabilir. Bu tanımdan yola çıkarak küreselleşme ve gönüllülük olguları arasındaki benzerliği görebiliriz. Küreselleşme, Soğuk Savaş sonrasının en moda ve fakat belki de en çarpıC1 ve uyarıc1 kavramlardan birisi olmuştur (Çalış, 2003:34). 
Bu süreç ile beraber Sivil Toplum Kuruluşları için yeni dönem başlamış ve bir birini etkileyerek gelișen ve değer kazanan iki olgu olarak küreselleşme ve sivil toplum kavramları dünya gündeminde önemli bir yer edinmiştir (Yıldız, 2006:23).

Soğuk Savaş'ın sona ermesi ile beraber ortaya çıkan küreselleşme sadece ekonomiyi değil siyasal, sosyal ve kültüre hayatı da etkilemiştir. Küreselleşmenin siyasi basamağı olan "siyasal küreselleşme” ulus devlet üzerinde büyük bir etkiye sahip olmuştur. Siyasal küreselleşme ile demokrasi yaygınlaşmış, uluslararas kurumların ve sivil toplum kuruluşlarnın etkinliği artmıştır. Küreselleşme süreciyle birlikte ortaya çıkan küresel sivil toplumlar, uluslar üstü bir seviyede faaliyet gösteren, gönüllülük ilişkisine dayalı, kâr amacı gütmeyen, bireylerin veya toplulukların gönüllü girişimlerinden oluşmaktadır. Küreselleşme sonucu demokrasi ve özgürlüklerin, küresel ölçekte yaygınlık kazanması eğilimi, devletler karşısında daha özgür yurttaşlardan oluşan bir toplum kurma beklentisi sivil topluma olan ihtiyacı ortaya koymustur (Yıldız, 2006: 49). Kamu politikalarını etkilemek isteyen devlet dışı aktör olarak kurulan bağımsız sivil toplum kuruluşlarının en önemli özelliği de gönüllülüik esasına dayalı çalışması olmuştur.

Buradan hareketle gönüllülük hareketlerini tıpkı küreselleşme kavramının "sınır ötesine akışı" gibi düşünebiliriz. Bu durumda gönüllülerin, küresel boyutta faaliyet gösteren aktörler olduğunun ve uluslararası gönüllüler ağının da küresel sivil toplumun ortaya çıkışında önemli bir faktör olduğunun vurgusunu yapabiliriz.

4.5. NeoLiberal İdeoloji ve Küresel Sivil Toplumun Etkileri

Giddens küreselleşmeyi, yerel olayların uzakta gerçekleşen olaylarla biçimlendirilmesi yoluyla Dünya çapında sosyal ilişkilerin yoğunlaşması olarak tanımlar (Bulut, 2003: 181). Küreselleşme süreciyle birlikte ortaya çıkan Küresel Sivil Toplum, küresel kapitalizmin neden olduğu sosyal eşitsizlikler ve adaletsizliklere karşı mücadele etmekte ve devlet-altı, devlet-üstü oluşumların önemini arttırmaktadır. Aynı zamanda sosyal refah programlarına katkıda bulunurken hem siyaseti hem de siyasetçiler etkiler ve siyasal karar alma süreçlerine aktif olarak katılım sağlar.

Küreselleşme süreciyle birlikte gelişen neoliberal anlayış ile devlet, eğitim, sağlık ve sosyal güvenlik gibi birçok alanda işlevini sivil topluma bırakmıştır. Küresel Sivil Toplumun gönüllü organizasyonları neoliberal politikaların etkisi altında olan dünyada, eğitim, sağlık, barınma gibi temel sorunlar konusunda alternatif çözümler üretmeye çalışmaktadır. Küresel Sivil Toplumun diğer işlevlerine değinecek olursak bunlar;

1. Küresel boyutta kamuoyu oluşturarak yoksulluğun azaltılması ve demokrasinin geliștirilmesini sağlamak,

2. Şeffaflı̆̆ı ve hesap verilebilirliği arttırarak finansal sorunları görünür hale getirmek,
3. Refah seviyesini yükseltmek adına oluşturduğu kamuoyu tartışmaları ve şeffaf faaliyetleri ile toplumsal farkındalığı arttırarak eşitsizliklerin ve sosya çatışmaların azaltılması konusunda rol oynamak,

4. Teknolojik gelişmelerden faydalanarak kitle mobilizasyonu sağlamak konferanslar, gösteriler ve toplantılar aracılığıyla gönüllüler ile beraber teme sorunlara alternatif çözümler üretmek.

Ancak tüm bu işlevlerine rağmen yetersiz fon, insan gücü ve ekipmanlar sebebiyle faaliyet kapasiteleri sınırlanmaktadır.

\subsection{Küresel Sivil Toplum Eleștirisi}

Küresel sivil toplumu, devletlerden ve piyasalardan bağımsız, vatandaşların, ulusal devletin sorumluluğunun dişında sahip oldukları faaliyet alanı şeklinde tanımlamak mümkündür. Bu anlamdaki küresel örgütler, çevreden-üçüncü dünyanın borçlarına, fakirlik, cinsiyet ayırımı, şiddet, çocuk köleliği, insan haklar ve demokratikleşmeye kadar bir dizi konuyla ilgilenmektedirler (Yıldız, 2006:58).

Neoliberalizm etkisinde gelişen küreselleşme sürecinde sivil toplum, birçok devlet tarafından resmi olarak "doğal ortak" olarak kabul edilmiş ve ulus-ötesi STK'lara devletler tarafindan kaynak sağlanmasına neden olmuştur. Kürese sivil toplum kuruluşlarının büyük çoğunluğunun Batı'da kurulması ve Batılılar tarafindan maddi olarak desteklenmesi bu STK'ların Batı'nın kontrolünde olduğu suçlamalarına neden olmuştur.
Siyasal ve kültürel olarak etkilenen sivil toplumun sermayeden bağımsızlığı sorgulanmaya başlanmıștır.

\section{Giris}

Yakın tarih, devlet içi krizler ve devletler arası çatışmalar nedeniyle kitlesel vahşetlere ve büyük ölçekli can kayıplarına tanık oldu. 1993'teki Somali felaketi, bir yıl sonra 1994'te yaşanan Ruanda katliamı, 1995’te Boşnak halkına karşı gerçekleşen soykırım, 1999'da Kosova'daki etnik temizlik, Soğuk Savaş sonrası dünyada uluslararası kamuoyunun gözleri önünde akıl almaz insani krizlerin gerçekleşebileceğini gösterdi. Temel insan hakları, dünya barışı ve güvenliği ile açıkça çelişen ve vicdanları sarsan bu felaketler, aslında Soğuk Savaş sonrası doğan güç boşluğunda özellikle Afrika ve eski Yugoslavya bölgelerinde birbiri ardına patlayacağı beklenen krizlerdi.

Tüm bu beklentilere rağmen uluslararası sistemin bu insani krizleri önlemede ve nasıl yanıt verdiğine baktığımızda, ne yazık ki efektif ve hızlı bir politika geliştirilemediğini görürüz. Bu hadiseler, başta Birleşmiş Milletler olmak üzere uluslararası kurumların sarsıcı felaketler karşısında etkisizliğini ve âtıl yapısını göstermiş ve sonuçta söz konusu kurumlar başarısızlık eleştirileriyle birlikte ciddi kınamalara maruz kalmıştır. Birleşmiş Milletler, tarihsel anlayışının bir yansıması olarak, İkinci Dünya Savaşı'ndan sonra egemenlik normlarını düzenlemis ve tüm üye devletleri eşit birimler olarak kabul etmişti. 
Soğuk Savaş Dönemi'nin sona ermesi ile ortaya çıkan "yeni dünya düzeni" fikri ile önem kazanan küreselleşme kavramını bir süreç olarak ele alırsak sadece ekonomik alanda değil aynı zamanda siyasal, kültürel, sosyal ve teknolojik alanlarda da yadsinamaz öneme sahip etkileri olduğunu görürüz. Bu süreçle birlikte mevcut dünya düzenindeki eski yapı ve kurumlar, köklü değişiklikler ve küreselleșme ile birlikte güçlenen ve gelișen yeni politikalar üretmek zorunda kamıştır. Küresel siyasetin belirlenmesinde başat rol oynayan ulus devlet aktörünün yanı sıra uluslararası kurumlar, çok uluslu şirketler ve sivil toplum kuruluşları siyasi arenada aktif rol almaya başlamıştır.

Küreselleșmenin önemi ve tanımını incelediğimizde, sivil topluma etkisi ve sivil toplumun dünya politikasında rolünün ve öneminin artmasına neden olduğu görülmektedir. Tüm bunları ele alırken tarihse süreç içerisinde öncelikle sivil toplum kavramının ortaya çıktığını görmekteyiz. Yaşanan teknolojik gelişmelerin de etkisiyle sosyal ilişkilerde mesafe ve sinıf engelleri azalmış, sosyal ilişkiler yaygınlık kazanmış ve tüm bu süreçler sivil toplumun gelişimine zemin hazırlamıştır. "1980 Sonrası Küreselleșmenin Etkisi ile Güçlenen Neo liberal Politikaların Sosyal Devletin Rolüne Etkisi ve Küresel Sivil Toplumun Ortaya Çıkışı" başlığını taşıyan bu çalışmada ilk olarak ilkel toplumdan devlete giden süreç tarihsel olarak ele alınmıștır. İkinci olarak küreselleşme öncesi sosyal devlet/refah devleti kavramı incelemesinin ardından neoliberal politikalar etkisinde devletin değişen rolüne değinilmiştir. Son olarak birlikte gelişen ve yükselen iki kavram olarak ele alınan küreselleşme ve sivil toplum kavramlarına ilişkin kavramsal çerçeve oluşturulmuştur.

Makalenin hipotezini neoliberal politikalar etkisinde önem kazanan küreselleşme kavramı ile beraber sivil toplum ve sivil toplum kuruluşlarının zaman içerisinde devletin rolünü üstlendiği varsayımı oluşturmaktadır. Buna bağlı olarak küreselleşmenin sivil toplumu hangi yönde etkilediği ve hangi yönde yetersiz kalarak eleştirilere maruz kald1ğ1 cevaplanmaya çalışılmıştır.

\section{Kaynakça}

Aktan, Coşkun Can (1995), 21.Yüz yıl İçin Yeni Bir Devlet Modeline Doğru Optimal Devlet, Kamu Ekonomisinin ve Yönetiminin Yeniden Yapılanması ve Küçültülmesine Yönelik

Öneriler, İstanbul: TÜSİAD Yayınları

Aktan, Coşkun Can (2008), Sosyal Refah Devleti, İstanbul: Okutan

Arendt, H. (1996) Geçmişle Gelecek Arasında, (Çev: B.S. Şener), İstanbul: İletişim Yayınları

Avc1, Onur. Bilim ve Gelecek Dergis Say1.73-Devletin Doğuşu

Bayraktar, Fesih (2017) Neo-Liberalleşme, Sivil Toplum Kuruluşları ve 'Projecilik': Eleştirel Bir Bakış, Amme İdaresi Dergisi, 105-142

Bulut, Nihat (2003). "Küreselleşme: Sosyal Devletin Sonu Mu?", Ankara Üniversitesi Hukuk Fakültesi Dergisi, 52 (2), 173- 197.

Clastres, Pierre. (2016), Devlete Karş Toplum (Çev. Mehmet Sert ve Nedim Demirtaş), Ayrıntı Yayınları, İstanbul.

Cooper, Terry L., Bryer, Thomas A. Ve Meek, Jack W., “Citizen-Centered Collaborative Public

Management", Public Administration Review, December, Special Issue, 2006, S. 76. (Ss. 7688).

Çalış, Şaban (2013) "Üç Tarz-1 Siyasetten Globalizme”, Küresel Sistemde: Siyaset, Yönetim Ekonomi, Derleyen. M. Aki
Çukurçayır, Konya, Çizgi Kitabevi

Doğan, İlyas. (2002), Özgürlükçü ve Totaliter Düşünce Geleneğinde Sivil Toplum, Alfa Yayınları, İstanbul.

Ertuğrul, Cemil. (2004), Tarımda Küreselleşme - Uruguay Görüşmeleri ve Sonrası, Odak Yayınevi, Ankara.

Ertuğrul, Cemil- Çolak, Olcay (2010) Finans Politik \& Ekonomik Yorumlar Cilt: 47 Say1:543

Küreselleşme Sürecinde Sosyal Devletten Neo-Liberal Devlete Geçiş

Kamat, S. (2004), "The Privatization Of Public Interest: Theorizing Ngo Discourse İn NeoLiberal Era”, Review Of International Political Economy, Vol. 11, No: 1 , S. $155-176$

Sencer, Muzaffer (1987), "Toplumların Evrimi”, Amme İdaresi Dergisi, S.1

Şenel, Alaeddin (2009). Kemirgenlerden Sömürgenlere İnsanlık Tarihi (2. Baskı). Ankara: İmge Kitabevi Yayınları.

Özcan, Mehmet Tevfik (2012) İlkel Toplumlarda Toplumsal Kontrol-Hukuk Dışı Mekanizmalar ve İlkel Hukuk, İstanbul

Yıldırım, Ergun. (2005), Apolitik Politikaların İnşacısı Olarak Sivil Toplum, Sivil Toplum, 3, (10), Ss. 63.

Yıldız, Osman (2006 Küreselleşme Sürecinde Sivil Toplum Kuruluşlarının Dünya Politikasında Artan Rolü: Uluslararası Kuruluşlar Açısından Bir Değerlendirme, Doktora Tezi Tester, K. (1992) Civil Society, London: Routledge Inc. 
Elektronik Kaynaklar

Https://Www.Teorivepolitika.Net/ İndex.Php/Arsiv/İtem/481-Devletsiz-Yasamak-MumkunMu

Hira, İsmail-Şan, Mustafa Kemal. (20.04.2009), Türkiye'de Sosyo-Politik Sistem ve Sivil

ToplumArayışları,

Http://Www.Sosyoloji.Sakarya.Edu. Tr/Turkiyede_Sosyopolitik_Sistemve_Sivil_Toplum.Pdf

Özcan, Emre, Http://Www.Sosyalhizmetuzmani.Org/Stk_Devlet.Htm, Sivil Toplum

Kavramının Tarihsel Gelişimi ve Sivil Toplum-Devlet İlişkisi 


\section{Birleşmiş Milletler Koruma Sorumluluğu Doktrininin}

(Responsibility to Protect) İnsani Müdahalelere Olan

Katkısı ve 2011 Libya Müdahalesi

Sümeyye Semiha BÜYÜK'

\section{Özet}

Makale bağlamında, insani krizler karşısında Karşı Sorumluluğun (R2P) sütunları değerlendirilmektedir. Öncelikle, egemenlik kavramının farklı yorumuna ve müdahaleleri meșru kılmak için R2P'de nasıl kullanıldığına yer verilerek öğretinin sorumluluk ayağı açıklanmıştır. Öğretinin ikinci ayağı olarak, bir müdahale için önleyici tedbirler değerlendirilir. Son olarak, insani krizlere olan tüm katkıları göz önünde bulundurularak, müdahale öncesi ve sonrası aşamalar, 2011 Libya müdahalesi örneği ile değerlendirilmektedir. Artıları ve eksileri ne olursa olsun, Koruma Sorumluluğu kavramı, kısa sürede eksiksiz bir normatif kılavuzun hazırlanmasına yönelik dikkate değer bir adım olmuştur.

\section{Anahtar Kelimeler}

Müdahale • Koruma Sorumluluğu (R2P) • Egemenlik • İnsani Krizler • Libya
The UN Responsibility to Protect Doctrine's Contribution to

Humanitarian Interventions and 2011 Libya Intervention

Sümeyye Semiha BÜYÜK

1 Brunel University London, International Relations MA, Post-Graduate, aksusumeyyes@gmail.com, ORCID: 0000-0003-4158-0614

Başvuru: 9 Ağustos 2021

Kabul: 30 Aralık 2021

Ilk Revizyon: 10 Eylül 2021

OnlineFirst: 31 Ocak 202

Copyright $\odot 2021$ İnsan ve Medeniyet Hareketi

http://toplumsaldegisim.com/ $20224(1) 88-99$

1 Brunel University London, MA in International Relations, Post-Graduate, aksusumeyyes@gmail.com,

\section{Keywords}

Intervention • Responsibility to Protect (R2P) • Sovereignty • Humanitarian Crises • Libya
In the context of the article, the pillars of the Responsibility to Protect (R2P) to contribute the humanitarian causes are evaluated. First of all, the responsibility pillar concept and how it is utilized in R2P to make interventions legitimate. As the second pillar of the report, the prevention measures for an intervention is assessed. post-intervention phase is evaluated with the example of 2011 Libya intervention. Regardless of the pros and cons, the concept of Responsiblity to Protect has been a remarkable step towards the preparation of a complete normative guide in a short time span. 
Bu nedenle, müdahalesizlik ilkesi uluslararası sistemin temel direklerinden biri olmuştu. Ancak mevcut krizler, devlet içi şiddetten kaynaklanan insan krizlere nasıl cevap verileceği ve "egemen" devletlerin sınırlarının ne olmas gerektiği sorularını beraberinde getirdi.

Uluslararası sistemin yapısından doğan bu sorunları ele almak üzere Kanada Hükümeti tarafindan Uluslararası Müdahale ve Devlet Egemenliği Komisyonu (ICISS) kuruldu. Farklı ülkelerde birçok uzmanın katıldığı çeşitli toplantılar sonrasinda bu komisyon 2001 yılinda "Koruma Sorumluluğu (Responsibility to Protect)" adlı bir doktrin yayınladı. Komisyonun temel amaçları, devlet içi ve devletler arası insani krizler karşısında uluslararası sistem için meşru bir müdahale yetkisi koymak, dışarıdan müdahale gereken bu durumlarda müdahalenin başlatılacağı kriz eşiğini belirlemek ve bu krizlere hangi yöntemlerle daha etkin yanıt verileceğini bulmaktı (Hehir, 2012, s.83). Koruma Sorumluluğu doktrini, yayımlandığı günden bu yana yeterliliği üzerine birçok tartışma yaratt1. Doktrin başlıca üç görüş ekseninde oldukça eleştirilmiştir: Koruma Sorumluluğunun devletlerin iç olaylarına müdahale firsatı kollayan yabancı devletler için aşırı bir zemin sağladığını savunanlar, doktrinin kriz anlarında harekete geçmek için yetersiz olduğunu savunanlar ve doktrinin mevcut krizlere çözüm bulamayacak kadar muğlak olduğunu savunanlar (Bellamy, 2012, s.59). Bunun- la birlikte doktrin, müdahale öncesi ve sonrası arasındaki sürece iyi geliştirilmiş bir çerçeve sunmuş ve insani krizlere yönelik normatif bir kılavuz oluşturmak için ilk adımları atmıştır. Bu makalede Koruma Sorumluluğunun etkinliğini ve güvenilirliğini olumsuz etkileyen eksikliklere atıfta bulunularak Koruma Sorumluluğunun insani amaçlara dikkat çeken normatif katkıları eleştirel bir şekilde incelenecektir. Bu makalenin üç ayaklı yapısı öncelikle Koruma Sorumluluğunun değer zemini ve yapısının temel bileşeni olarak egemenlik terimine odaklanmaktadır. İkinci olarak Koruma Sorumluluğunun can kayıpları ve kitlesel yıkımlara neden olan kriz olgusunun öncesinde devlet içi krizi çözmenin hayati bir parçası olarak önleme ayağı ele alınacaktır. Son olarak, bir insani kriz durumunda Koruma Sorumluluğunun ilk uygulama örneği olarak Libya müdahalesi incelenecektir.

\section{a. Bir Sorumluluk Olarak Egemenlik}

"Egemenlik" kavramı, uluslararası ilişkiler disiplininde tartışmalı bir kavram olagelmiştir. Terim çeşitli şekillerde değerlendirilmiş, dolayısıyla kısmen de olsa herhangi bir küresel çerçevenin standartlarını ve kılavuzlarını belirleme noktasında bir yetersizliği ortaya koymaktadır (Krasner, 2009). Bu makale çerçevesinde en baskın egemenlik kavramı üzerinde durulacaktır. Westphalia tipi egemenlik kavramı, devletlerin kendi yönetişim sistemleri için kendi kaderini tayin etme ve kendi kültürlerini belirle- me haklarını vurgular. Bu perspektiften bakıldı̆̆ında, "bölgesel sahiplenme ve dış aktörlerin yerel otorite yapılarından dışlanması" egemenliğin temelidir ve müdahalesizlik normu devlet olmanın temel unsurudur (Krasner, 2009, s.20) 18. yüzyıldan 1970'e kadar müdahalesizlik, 1970 tarihli Devletler Arasında Dostça İlişkiler ve İşbirliğine İlişkin Uluslararası Hukuk İlkeleri Konusundaki Bildirge gibi uluslararası anlaşmalarda tekrar tekrar onaylanmıştır.

Egemenlik kavramına olan bu geleneksel yaklaşımın kökeni bakıldığında sömürgeciliğin yeniden yükselişine karş1 koymak için sömürge sonrası dönemde müdahelesizlik ilkesiyle pekişmis olduğunu görebiliriz. Buna karşın, müdahalesizlik ilkesini içeren geleneksel egemenlik kavramı insan haklarının desteklenmesi, demokrasi, insanlığa karşı suçların önlenmesi arasında zorlu ilişkiler doğurmuştur. Buna mukabil, özellikle Soğuk Savaş sonrası dönemde yoğunlaşan devlet içi çatışmalardaki sistematik insan hakları ihlallerine ve korkunç felaketlere karşı gelişen muğlak tutumların zemini oluşturmuştur.

Geleneksel egemenlik kavramının mevcut insani krizlere yanıt vermede engel teşkil eden bu problematik yönünün bir sonucu olarak Koruma Sorumluluğu Doktrini Komisyonu (ICISS), ilk olarak egemenliğin anlamını inceledi. Bu tarihi yaklaşıma yanıt olarak ICISS, takdire şayan bir şekilde geleneksel kavramları yeniden değerlendirmeye tabi tuttu.
Egemenlik fikri, ICISS komisyonunun ana bileşeni olarak belirlendi. Sonrasında Kofi Annan'in sorduğu kritik soru, 2001 yılında Koruma Sorumluluğunun çıkış noktası olan alternatif egemenlik kavramını yarattı.

"İnsani müdahale gerçekten de egemenlige kabul edilemez bir saldıriysa, bir Ruanda'ya, bir Srebrenitsa'ya, paylaştığımız insani değerlerin her ilkesini zedeleyen büyük ve sistematik insan haklarn ihlallerine nastl yant verilmeli? (ICISS, 2001a, s. vii)

Verilen cevap ve doktrinin ana temas1 "egemen" devletlerin vatandaşlarını devlet sınırları içinde belirli düzeyde zararlardan, felaketlerden, toplu katliamlardan ve soykırımlardan korumakla yükümlü olduğuydu. Bu sebeple, ICISS doktrininde egemenlik kavramı insan haklarıyla birbirinden ayrılamaz bir bütünlükle ele alınd1. Aralarında tutarlılı̆ğ sağlamak için bu yorum, egemenliğe bir "sorumluluk" olarak yaklaştı. Böylece, Westphalia anlaşmasından bu yana egemen devletlerin üç özelliği, konuyu insan hakları açısından ele alan dördüncüsü tarafindan desteklendi (Weiss, 2004, s.138). Çünkü bir sorumluluk olarak egemenlik iki temel varsayıma dayanmaktadır; Birinci varsayım bireylerin "devredilemez" hakları olduğudur, ikincisi varsayıma göre ise hükümetler vatandaşlarının doğal ve genel haklarını korumaya yönelik sorumluluğu yerine getirmezlerse uluslararası toplumun gerekli önlemleri almakla yükümlü olduğudur (Bellamy, 2009, s.20). 
Egemenlik kavramı tarih boyunca çeşitli sorumluluklarla ilişkilendirilmiştir faka bu defa değișen sorumlulukların bağlamıdır, yani kime karşı sorumlu olunduğudur (Bellamy, 2009, s.33). Ayrıca, görece yen olan bu yaklaşım, kısa sürede ana akım politikaya taşınmış ve tüm devletlerin uluslarını vahşetten koruma görevi uluslararası arenada ön plana çıkarılmıştır.

Bununla birlikte Koruma Sorumluluğu doktrininde bu yorum pek çok eleştiriyi de beraberinde getirdi. Örneğin bir "sorumluluk olarak" egemenlik yaklaşımının ICISS'in düşündüğü gibi revizyonist bir yaklaşım olmadığı bunlardan biriydi (Weiss, 2004, s. 139). Bellamy, bunun “...ne yeni, ... ne de radikal” olduğunu belirtti (Bellamy, 2009, s.20) Gerçekten de, egemenliğin sorumluluk olarak kavramsallaştırılmasının tarihi, Amerika'nın Bağımsızlık Bildirgesi'nde ilk kez telaffuz edildiği 1776 yılına kadar uzanmaktadır. O zamanlar, egemenin sorumluluğunun kapsamı, Soğuk Savaş'in sonuna kadar temel insan haklarından çok kendi kaderini tayin hakkına atıfta bulunuyordu. Soğuk Sava sonrası dönem, kavramın insan haklar açısından tekrar yorumlanmasının ve insan haklarının kavramın ikinci unsuru olması açısından önemli bir dönüm noktası olmuştur. Ülke İçinde Yerinden Edilmiş Kişiler özel temsilcisi Francis Deng, 1996 yllında terime yeni bir çehre kazandırarak egemenliğin yönetişim açısından hesap verebilir olması konusunda belirli sorumlulukları olduğunu savunmuştu (Hehir, 2012, s.69). Onun egemenlik ve temel insan hakları arasında kurduğu pozitif ilişkisinin başlangıç noktası, insanları korumaya yönelik öncelikli sorumluluğu kabul etmesi ve korumaya yönelik sorumluluklarını yerine getirmeyen devletler için uluslararası topluma ilk kez rol vermeye çalışmasıyla olmuştu. Bu bağlamda, ICISS doktrininin insani krizlere müdahalenin doğas1nı değiștiren radikal bir değişiklik değil, yakın geçmişte verilen yanıtların bir birikimi olduğu söylenebilir.

Bununla birlikte, insani krizlere etkin bir şekilde yanıt verilmesi için güçlü bir dayanak noktası oluşturan bu doktrin temelinde "bir sorumluluk olarak egemenlik" fikri yatmaktadır. En önemlisi de teorik düzeyde vakalar için bir değer çerçevesi belirlenmiş olması ve meşru önleme söyleminin önünün açılmış olmasıdır.

\section{b. Önleme}

Önlemenin müdahaleye nazaran daha geniş bir siyasi kesim tarafindan desteklendiği yadsınamaz bir gerçektir. Ölümcül krizlerin önlenmesi, Birleșmiș Milletler'in uzun süredir devam eden amaçlarından biri olmuştur; bunu "savaş belasından" "yeni nesilleri kurtarmak" olarak da ifade edebiliriz (UN.org, tarih yok). Hem insani amaçlar hem de ekonomik faktörler, önleyici tedbirlerin önemini merkezileștirmiștir. Koruma Sorumluluğunun üç ayaklı yapısının temel unsurlarından biri olan "önleme sorumluluğu”, dört ana suçun oluşmasını önlemeyi amaçlamaktadır: soykırım, savaş suçları, etnik temizlik ve insanlığa karşı işlenen suçlar. ICISS, önlemenin "tek başına koruma sorumluluğunun en önemli boyutu” olduğunu savunmuştur (2001a, s. xi). ICISS doktrini ile birlikte insani acil durumların önlenmesi için uygun ve etkili tedbirlerin alınmasinda en önemli rol uluslararası topluma verilmiştir; bu rolün gerekleri ise etkin uyar sisteminin kurulması ile mevcut siyas araçların ve siyasi iradenin (istemin) belirlenmesidir (ICISS, 2001, s. 20). Tüm bileșenleriyle önleme konsepti başarılı olursa uluslararası toplumu müdahale etmeye zorlayan insani acil durumların sayısı da azalacaktır.

Öte yandan müdahalecilik karşıt şüphecilere bir yanıt olarak, Koruma Sorumluluğunun "önleme” bileșeni dikkate değer bir çözüm sunmaktadır. Bu nedenle, devlet içinde egemenlik ve in san hakları arasında makul ve messru bir ilişki kurmak için kök nedenlerin belirlenmesi ve bu nedenlere yönelik önleme çabaları çok önemlidir. Ek olarak, önleyici tedbirlerin eklenmesiyle bireylerin haklarına değer verilmis ve Koruma Sorumluluğu mağdurlar lehine işlenmişti (Bellamy, 2009, s.98). Tüm bunlar, devlet içi çatışmaların ortaya çıkmasından önce ekonomik ve politik "kök nedenlerinin” altını çizmektedir ve ICISS'in ikinci katkısına yönelik temas edilebilecek değerli bir noktadır.

Öte yandan, "önleme sorumluluğunun” ne kadar kapsamlı olması gerektiğ ve "başarılı olması için hangi önlemlerin alınması gerektiği” doktrinde belirsiz kalmıştır. Koruma Sorumluluğu kavramı, "tüm vatandaşlar için adil muamele ve adil firsatlar sağlanmasının çatışmaların önlenmesi noktasında sağlam bir temel oluşturduğu" varsayımına dayanır (ICISS, 2001, s.21); erken uyarı, kök neden önleme ve doğrudan önlemeye yönelik kriterler belirler. Devlet içi silahlı çatışmaların çok sayıda kök nedeni olabileceği düşünüldüğünde önleme araçları, müdahaleci devletler için hem maliyetli hem de zor politikalar gerektiren daha geniş kapsamlı yapısal değişiklikleri beraberinde getirmektedir. Daha da önemlisi yapısal önleme, "kalkınma hakkı" ve “insan güvenliği kavramı” üzerine daha geniş tartışmaların önünü açmaktadır (Bellamy, s. 100). Böylelikle yapısal önleme, Koruma Sorumluluğunun sınırlarını aşmakta ve kavramın diğer unsurları ile tutarsızlıklara yol açmaktadır.

ICISS doktrininde dahil edilen yapisal önleme, muğlak bir özellik olarak karş1mıza çıkmaktadır. Silahlı çatışmaların önlenmesi başlı başına önleyici tedbir olarak savunulmaktadır ancak Koruma Sorumluluğunun geri kalanı yalnızca dört suça (soykırım, savaş suçları, etnik temizlik ve insanlığa karşı suçlar) yanıt olarak 'haklı amaç eşiği' odaklıdır. Bellamy'ye göre, Koruma Sorumluluğunun tutarsız özelliği "kapsamlılık ikilemine" neden olmuştur (Bellamy, 2009, s.131). İkilemden kasıtsa şudur: Çatışmaların önlenmesi her ne kadar meseleleri halk lehine değiştirmeye çalışsa da kavra- 
mın belirsizlikleri nedeniyle sürecin sonunda hiçbir şeyi değiştirememektedir. Hangi önleyici tedbirin dört suçun önlenmesine yönelik olduğu konusundak belirsizlik, doktrini ayırt edici özelliğ olmayan bir şekle büründürmektedir. Sonuç olarak, önleme üzerine Koruma Sorumluluğu tartışması bağdaştırıcı ve geliştirici bir formülün ilkelerini oluşturmak yerine genel öneriler dahilinde basit bir genel bakış sunmaktadır.

Basit ifadesiyle önleyici tedbirler, müdahaleci devletlerin hem maliyetlerini hem de anlaşmazlıklarını azaltmanın ilk engeli olarak kabul edilebilir. Buna karşın yalnızca etkin dar kapsamlı tedbirle önlemeyi gerçekleştirme potansiyeline sahiptir, kök nedenlere çözümler bulmaya çalışmak yerine bu odağa göre hareket edilmelidir. Dolayısıyla Koruma Sorumluluğunun önleme ikilemi, insani amaçlara yönelik zayıf argümanlar sunmaktadır.

Bu makalenin son bölümüne geçmeden önce bir şeyi belirtmek gerekir: Hem "bir sorumluluk olarak egemenlik" hem de "önleme" perspektiflerinden doktrin, savaş ve şiddet vakalarının tümünde mağdurlara öncelik vermektedir. İlk bölgesel toplantıdan sonuncusuna kadar, ICISS doktrini hazırlanırken, insan hakları konusundaki fikir birliğine dayal uzlaşı sürecin belirleyicisi olmuştur. Bu bağlamda Koruma Sorumluluğu, müdahale tartışmalarının eksenini "müdahale edenlerin hakları"ndan "mağdurların hakları"na çevirmeye çalıșmıștır (Bellamy, 2009, s.60). Egemenliğin yeniden kavramsallaştırılması, kitlesel vahşete karşı harekete geçme kararlılığı, önleyici tedbirler ve yeniden yapılandırma politikaları ile tüm bileşenler, müdahale hakkını tersine çevirmiş, müdahale hakkı kavramı yerine tüm devletlerin ortak sorumluluğunu ve mağdurların haklarını getirmiş, mağdurlara ve bireylere öncelik vermiştir. Nitekim gerçekten de "haklı amaç eşiği çok yüksektir”, “büyük çaplı can kayıpları ve etnik temizlik" ile "suçun gerçekleşmiş olması veya suçüstü yapılması" terimleri ırk ayrımcılığ 1 ve sistematik insan hakları istismarları gibi ciddi suçları içermemektedir (Weiss, 2004, s.139). Ancak Koruma Sorumluluğu metni değerler açısından güçlü bir metindir. Dolayısıyla devletin attığ 1 adımların bir sorumluluk olarak egemenlik ilkesini karşılamadığı ve tüm önleyici tedbirlerin tükendiği durumlarda mağdurların haklarının korunması amacıyla müdahaleye yönelik bu yeni yaklaşımın doğduğunu söylemek mümkündür.

\section{Libya Müdahalesi}

İlk Koruma Sorumluluğu deneyimi olan NATO'nun Libya'ya askeri müdahalesi öğreti için bir dönüm noktası olmuştur. Bu açıdan teorik ve soyut varsayımlar düzeyinden gerçek durumlara yani pratiğe geçişte öğretinin fiili katkılar1nın incelenmesi mühimdir.

Öncelikle Libya müdahalesi, açıktan ve hızlı bir yanıt niteliğindeydi; kendinden önceki Irak işgali uygulaması ile karşılaştırıldığında Ortadoğu'da görece tartışmasız bir müdahaleydi (Hehir, 2015, s.293). BM'nin 1970 ve 1973 tarihli Libya Kararları, Libya makamlarının kendi nüfusunu koruma noktasındaki yetersizliğini ve uluslararası adımlar atılmasının gerekliliğini açıkça belirtmekteydi. Ko ruma Sorumluluğunu savunanlar için bu öğretinin bir zaferiydi. Çünkü BM’nin müdahale kararı, yeni "Koruma Sorumluluğu” doktrininin kavramsallaştır masıyla birlikte Güvenlik Konseyi'nde önemli bir politika değișikliği olarak değerlendirilmiştir (Hehir, 2015, s.297) Koruma Sorumluluğunun savunucuları, BM tarafindan takip edilen müdahale öncesindeki aşamaların çoğunun Libya hükümetinin koruma konusundaki yetersizliği üzere geliştiğini iddia etmektedir. Buna göre önleyici tedbirler ortaya konulmaya çalışılmış, ancak daha sonra devletin halkına karşı görevi uluslararası kuruluşlar tarafindan yerine getirilmiştir. Gerçekten de Koruma Sorumluluğunun olumlu etkisiyle uluslararas toplumun Libya'da insanlığa karşı suçların önlenmesi için hızlı bir uzlaşı örne ği sergilediği söylenebilir. Ayrıca birçok müdahale taraftarı, Libya müdahalesinin geçmişteki operasyonların olumsuz etkisini azaltarak yeni adımlarda insani amaçları tetikleyebileceğini düşünmüştür (Hehir, 2015, s. 300). Dolayısıyla Libya müdahalesi, Koruma Sorumluluğu çatısı altındaki insani müdahaleler için yeni bir dönem olabilirdi.

Bununla birlikte, 1973 tarihli BM Libya Kararı, Libya makamlarının kend vatandaşlarını koruma görevine atıfta bulunurken uluslararası toplumun mağdurları koruma görevinden bahsetmemiştir (Hehir, 2015, s. 298). Bu durum, Libya müdahalesinin Koruma Sorumluluğu doktrininin bir yansiması olup olmadığına dair belirsizlik yaratmıștır. Ayrıca, BM'nin Somali hakkındaki 794 sayılı ve Silahlı Çatışmalarda Sivillerin Korunmasına ilişkin 1265 sayılı Kararı, Koruma Sorumluluğu doktrini öncesinde de bu tür krizlere verilen uluslararası tepkilerde ahlaki motivasyonun erken belirtilerini göstermektedir. Bu açıdan bakıldığında dönemsel ivme ne yönde olursa olsun uygulamalar BM Güvenlik Konseyi ve 5 Daimi Üyenin potansiyel gücü gibi görünmektedir. Ayrıca, müdahale ve müdahale sonrası döneme ilişkin tartışmalar, Libya'da iç açıcı sonuçlara işaret etmemektedir. Koruma Sorumluluğu kapsamında değişikliklere yönelik tedbirler etkisiz kalmıştır, pek çok kişi NATO müdahalesinin Libya'da insani amaçlardan ziyade rejim değișikliğini hedeflediğini ve istikrarsızlığın Kaddafi rejiminden daha fazla sivil ölüme yol açtığını savunmuştur. Diğer bir deyişle Korumu Sorumluluğu Libya'daki birincil hedeflerini gerçekleştirememiştir.

$\mathrm{Bu}$ çerçevede, Koruma Sorumluluğunun uygulanmasının Libya özelinde hem tartışmalı hem de paradoksal olduğu düşünülebilir. Genel anlamda Suriye gibi çok benzer krizlerde neden herhangi bir müdahalenin uygulanmadığı sorusu da pratikte daha bulanık bir tablo ortaya koymaktadır. 


\section{Sonuç}

Bu makale kapsamında Koruma Sorumluluğunun insani amaçlara katkıları değerlendirilmiştir. İlk olarak egemenliğin geleneksel anlamı açıklanmıştır. Çünkü "Bir sorumluluk olarak egemenlik" kavramsallaştırmasının gücü ancak kendi tarihsel süreci içinde açıklığa kavuşturulabilir. Bu kavramsallaştırma oldukça eleştirilmiş olsa da terim Soğuk Savaş sonrası dönemdeki koşullarda yapılan müdahalelere hukuki zemin oluşturmak için kullanılmıştır. Lehte ve aleyhte görüşlere bakılmaksızın egemenlik kavramı insani amaçlarla olumlu bir şekilde şekillenmiştir ve bu değişim için önemli çabalardan biri de Koruma Sorumluluğudur.

İkinci olarak önleme kavramı ve tedbirler üzerinde durulmuştur. Bu makalenin bakış açısında önleme ayağı, egemenlik ve müdahale arasında makul bir denge kurmak için çok önemlidir. Koruma Sorumluluğunun hayati unsurlarından biri olarak ICISS doktrini, önlemenin önemine dikkat çekmektedir. Büyük ölçekli can kayıpları meydana gelmeden insani acil durumların önlenmesinin arzu edilen bir durum olduğu inkar edilemez. Bu açıdan önleme ayağı, insani amaçlara en çok katkı sağlayan etkenlerden biridir. Koruma Sorumluluğunun önlemeye yönelik vaat ettikleri kısa sürede uluslararası topluma da yansımıştır, bu durum Koruma Sorumluluğunun başarılarından biri olarak görülebilir Bununla birlikte, nihayetinde önleme sorumluluğu henüz beklenen başarıyı getirmemiştir. Bu durum Koruma Sorumluluğundaki önleme söyleminin çok tartışmalı ve yetersiz olmasıyla izah edilebilir. En önemlisi de Koruma Sorumluluğundaki önleme ayağı, doktrinin geri kalanıyla tutarsızdır. Pratikte önleyici tedbirler çeşitlilik göstermekte ve büyük ölçüde devletlerin siyasi iradesine dayanmaktadır. Bu durum, bir kez daha egemenlik konusunda kızışan tartışmalara yol açmıştır. Hangi önleyici tedbirlerin (yapısal mı yoksa doğrudan mı) gerekli olduğunun belirlenmesi gerekmektedir, çünkü hangi "kök neden"in soykırıma götürdüğünü bilmek çok zordur. Ne yazık ki görece başarısına rağmen Koruma Sorumluluğundaki önleme kavramının meselelerle pratik olarak ilgilenmek için yeterli olmadığı çok açıktır.

Makalenin üçüncü bölümünde, 2011 yılında gerçekleştirilen NATO'nun Libya Müdahalesi ele alınmıștır. Müdahale öğretinin uygulama noktasındaki katkısını ortaya koymaktadır. Müdahale görece hızlı gerçekleşmiş ve çok fazla tartışmaya neden olmamıştır. Ayrıca, 1973 Kararıyla devletin "sorumluluğunun" belirtilmesi açısından da farklı etkiler görülebilir. Ancak Koruma Sorumluluğu doktrininin başarılı olduğunu söylemek için henüz çok erkendir. Üstelik Libya müdahalesi de "eşsiz” bir örnek olarak literatürde yerini korumaktadır. Hehir'in deyimiyle, "asla faktörlerin takımyıldızı olmamalıydı” (Hehir, 2015, s.301). Dikkat çeken bir diğer nokta ise askeri gücün tercih edilen alternatif olarak kullanılması ve "haklı sebep” eşiği ile "son çare" kriterinin dikkate alınmamasıdır (Saba \& Akbarzadeh, 2017, s.19) Tüm bu eleştiriler, Koruma Sorumluluğunun Libya örneğinde ciddi katkılar sağlamadığı ve etkinliğinin çok sınırlı olduğu yönündeki varsayımları güçlendirmiştir.

Sonuç olarak, yukarıda bahsedilen tüm artı ve eksileriyle Koruma Sorumluluğunun eksiksiz bir normatif rehber hazırlanmasına ilişkin ilk adım olduğunu söylemek yerinde olacaktır. Üstelik bir fikrin uluslararası alanda bu kadar geniş ölçekte kabul görmesi açısından değerlendirildiğinde bile çok kısa zamanda bir ivme kattettiği göz ardı edilmemelidir; Evans'ın da söylediği gibi, "fikir tarihi açısından ve özellikle asırların alışılmış bilgeliğine meydan okuyan bir fikir için sadece göz açıp kapayıncaya kadar bir zamanda...” (Evans, s.10) bunu başarmıştır. Bu nedenle, Koruma Sorumluluğunun gelecek deneyimleri, uzun vadede insani amaçlara katkıları için belirleyici olacaktır. 


\section{Kaynakça}

Bellamy, A., 2009. Responsibility to Protect: The Global Effort to End Mass Atrocities. Polity Press, Cambridge.

Evans, G., (2009). The Responsibility to Protect: Ending Mass Atrocity Crimes Once and for All. Irish Studies in International Affairs. Cilt 20, s. 7-13.

Hehir, A. (2015). Humanitarian intervention. Johanneshov: MTM.

Hehir, A., 2012. The Responsibility to Protect: Rhetoric, Reality and The Future of Humanitarian Intervention. Palgrave Macmillan, London.

Krasner, S., (1999). Sovereignty: Organized Hypocrisy. Princeton Univ. Press

Nato.int. (1999). Resolution 1265. [çevrimiçi] Erișim adresi: https://documents-dds-ny.un.org/doc/UNDOC/GEN/ N99/267/94/PDF/N9926794.pdf?OpenElement [Erişim tarihi: 2 Aralık 2017].

Nato.int. (2011). Resolution 1973. [çevrimiçi] Erişim adresi: https:// www.nato.int/nato_static/assets pdf/pdf_2011_03/20110927_110311UNSCR-1973.pdf [Erişim tarihi: 2 Aralık 2017].

Saba, A. and Akbarzadeh, S. (2017) The Responsibility to Protect and the Use of Force: An Assessment of the Just Cause and Last Resort Criteria in the Case of Libya. International Peacekeeping, s.1-24.

Securitycouncilreport.org. (1992). Resolution 794. [çevrimiçi] Erişim adresi: http://www.securitycouncilreport.org/ atf/cf/\%7B65BFCF9B-6D27-4E9C-8CD3-CF6E4FF96FF9\% 7D/Ch a $\% 20$ VII\% 20 SRES\%20794.pdf [Erişim tarihi: 2 Aralık 2017].

The Responsibility to Protect. (2001) Ottawa: The International Commission on Intervention and State Sovereignty

Un.org. (tarih yok). Gerekçe. [Çevrimiçi] Erişim adresi: http://www.un.org/ en/sections/un-charter/preamble/index. html [Erişim tarihi: 2 Aralık 2017].

Weiss, T. (2004). The Sunset of Humanitarian Intervention? The Responsibility to Protect in a Unipolar Era. Security Dialogue, 35(2), s.135-153. 


\section{Elektronik İnsan Kaynakları Uygulamalarının Algılanan Net Faydaya Etkisi ve Kullanım Kolayliğinin Aracı Rolü: Türkiye Banka Sektöründe Bir Araştırma}

Prof. Dr. Yonca Deniz GÜROL ${ }^{1}$ Furkan BAĞRIYANIK²

\section{Özet}

21. yüzyılda teknolojinin gelişmesi, bilgisayar kullanımının artması, internetin yaygınlaşması ve küreselleşmenin etkisiyle iş hayatında büyük değişmeler yaşanmıştır. Bu değişimler sayesinde geleneksel yöntemler terk edilmiş yerine daha kolay ve pratik çözümler sunan uygulamalar tercih edilmiştir. Örgütlerin ve çalışanların alıskanlıkları da bu durumdan etkilenmistir. Geleneksel insan kaynakları yönetimi tamamen karlılık odaklı, insanları sadece üretim faktörü olarak gören ve çoğunlukla evrak işleriyle ilgilenmekteyken günümüzde uygulanan elektronik insan kaynakları yönetimi çalıșanların, işletmenin ve hizmet verilen kurum veya müșterilerin tüm ihtiyaçlarını gidermeye odaklanmıştır. Bu çalışmada elektronik insan kaynakları (Operasyonel E-IK, İlişkisel E-IK ve Dönüșümsel E-IK) uygulamaları ile algılanan net fayda etkisi arasındaki ilişkide kullanım kolaylığının aracı rolü incelenmistir. Bu çalışmada sırasıyla elektronik insan kaynakları uygulamalarının modellenmesi, amacı, önemi, kapsam çalışma grubu, veri toplama araçları, veri toplama süreci, veri analiz işlemleri ve sınırlılıkları incelenmiştir.

\section{Anahtar Kelimeler}

Elektronik İnsan Kaynakları Uygulamaları • Algılanan Net Fayda

- Kullanım Kolaylığ
1 Prof. Dr. Yonca Deniz Gürol, Yıldız Teknik Üniversitesi, Sosyal Bilimler Enstitüsü, İşletme Anabilim Dalı, İnsan Kaynakları Yönetimi, gurol@yildiz.edu.tr, ORCID: 0000-0002-0618-5750

2Yldı Teknik Üniversitesi, Sosyal Bilimler Enstitüsü, İsletme Anabilim Dalı İnsan Kaynakları Yönetim Tezli Yüksek Lisans Öğrencisi, fbagriyanikk@gmail.com, ORCID: 0000-0003-1644-5533

Başvuru: 27 Ağustos 2021

Ilk Revizyon: 24 Eylül 2021
The Effect Of Net Perceived Benefit Of Electronic Human Resource Applications and The Intermediate

\section{Role Of Practicality}

Prof. Dr. Yonca Deniz GÜROL ${ }^{1}$ Furkan BAĞRIYANIK ${ }^{2}$
In the 21st century, there have been substantial changes in business life with the development of technology, the increase in computer use, the spread of the internet and globalization. By means of these changes, instead of abandoning traditional methods, applications that offer easier and practical solutions have been preferred. The habits of organizations and employees have also been affected by this situation. While traditional human resources management is purely profitability-oriented, seeing people only as production factors and mostly dealing with paperwork, today's electronic human resources management applications are focused on meeting all the needs of employees, businesses, and institutions or customers. In this study, the mediating role of ease of use in the relationship between electronic human resources (Operational E-HR, Relational E-HR, and Transformational E-HR) applications and the perceived net benefit effect was examined. Furthermore, modeling, purpose, importance, scope working group, data collection tools, data collection process, data analysis procedures, and limitations of electronic human resources applications were examined respectively.

\section{Keywords}

Electronic Human ResourcesPractices • Net PerceivedBenefit • Ease of Use 1 Prof. Dr. Yonca Deniz Gürol, Ylldız Technical University, Institute of Social Sciences, Department of Business Administration, Human Resources Management, gurol@yildiz.edu.tr, ORCID: 0000-0002-06185750

2 Ylldiz Technical University, Institute of Social Sciences, Department of Business Administration, Human Resources Management Master’s Student with Thesis, fbagriyanikk@gmail.com, ORCID: 00000003-1644-5533 
Araștırmanın konusu, amacı ve önemi incelendiğinde ülkemizde insan kaynakları konusunda literatürde çok fazla çalışmanın mevcut olduğu ancak elektronik insan kaynakları üzerine sinırl sayıda çalışma bulunmakla birlikte bu sayının son yıllarda ufakta olsa artışta olduğu gözlemlenmektedir. Birbirinden bağımsız olarak birçok incelemeye konu olan algılanan kullanım kolaylığı ve algilanan net fayda kavramlarının elektronik insan kaynakları üzerindeki etkiler konusunda bir çalışmaya rastlanmamıs olması bu çalışmayı kıymetli kılmak tadır. Bu çalışmanın organizasyonlara ve akademik çalışmalara fikir vereceği düşünülmektedir. Bu tez çalışmasının amacı elektronik insan kaynakları uygulamalarının işletmelerde var olan bilgi sistemleri ve teknolojilerini ortaya çkarmak; kullanım seviyelerini tespit etmek, şirket, yönetici ve çalışan açısından elektronik insan kaynaklarının sağladığ avantajları belirlemek; çalışanlar için önemli konuları tespit etmek ve elektronik insan kaynakları uygulamaları ile ilgili memnuniyetlerini ölçmektir.

Çalışmanın en büyük önemi günümüzde işletmeler, bilgisayar teknolojisine yatırım yapmakta ve eline geçirdiğ tüm bilgileri bir sistem içinde toplamaktadır. Buradaki amaç, işletmelerin işine yarayacak veya faydalı olacak bilgileri özümseyen sistemler geliştirmek ve bu bilgileri işletmenin performansını arttırıcı şekilde kullanmasını sağlamaktır.
İnsan kaynakları yöneticileri de bu gelişmeler ışı̆̆ında bilgisayar teknolojilerine yatırım yapmaktadır. Ancak, çalışanların performansını artırmak sadece teknolojik yatırım yapmakla mümkün değildir. Bunun için yapılan bu yatırımlar tüm birimler tarafindan sahiplenilmelidir. Bu nedenle, çalışanların bilgi işlem sistemlerine yaklaşımları, bu sistemlerden ne kadar yararlandıkları ve sistemlere karşı tutumları önem arz etmektedir. İşletmelerin kurmuş olduğu sistemi doğru algılamış olmaları sistemlerin işleyişi, üstünlükleri ve zayıflıkları hakkında bilgi sahibi olmaları gerekmektedir. Araştırmanın sonucunun alan yazınına katkı sağlayacağı ve gelecekte yapılacak çalışmalara yol gösterici nitelikte olacağ1 düşünülmektedir.

$\mathrm{Bu}$ araştırmada, işletmelerin elektronik insan kaynakları yönetimi uygulamalarının algilanan net faydasının etkisinin belirlenmesi amaçlanmaktadır. Belirlenen bireysel teknolojik hazır oluş düzeylerinin teknoloji kabulü kapsamında çalışanların E-İKY uygulamalarını ne derecede kaliteli ve kullanımlarını kolay algıladıkları ölçülmeye çalışılmıştır. Bu çalışmanın en temel amacı, Türkiye'deki bankalarda E-İKY'nin fayda ve benimsenmesinin en önemli belirleyicilerini tespit etmektir.

Bu araştırmada, aşağıdaki temel varsayımlar kabul edilmiştir.

1) Verilerin toplanacağı örneklemin, evreni temsil edebilir nitelikte olduğu varsayılmaktadır.
2) Örneklemi oluşturan kişiler, anket sorularına hiçbir etki altında kalmadan samimi, dürüst ve doğru olarak cevaplandırdığı varsayılmaktadır

3) Anket sorularını yanıtlayan İK bölümü çalışanları, anketteki sorular yanıtlayabilecek yeterli bilgiye sahip oldukları varsayılmaktadır.

4) Araştırmada kullanılan veri toplama araçlarının, ölçülmek istenilenler doğru ölçtüğü varsayılmaktadır.

Araștırmanın kısıtlarında ise uygulama alanı olarak bu araştırmada Bankacılık ve Finans sektöründe faaliyet gösteren, Türkiye'de aktif olarak hizme veren bankaların İnsan Kaynakları Bölümündeki direktör, müdür, yönetmen, uzman ve uzman yardımcisı unvanlarıyla çalışan kişilerden elde edilen veriler kullanılmıştır.

Bu anketin uygulanması için kişi sayıs1 sinırlılığında ise Bankacılık ve Finan sektöründe faaliyet gösteren, Elektronik İnsan Kaynakları Yönetimi uygulamalarını kullanan bankaların, insan kaynakları bölümünde çalışan, elektronik insan kaynakları yönetimi uygulamaların kullanma yetkisi olan toplam 196 kişiye uygulanmıştır.

Ayrıca araştırmanın değişkenleri, E-İKY uygulamaları, E-İKY uygulamalarında algılanan kullanım kolaylığı ve E-İKY uygulamalarından algilanan net fayda şeklinde sıralanmaktadır.

Araştırmanın modellenmesinde ise nicel araştırma yöntemlerinden ilişki- sel tarama modeli kullanılmıştır. Araştırma iki ve daha çok sayıdaki değişken arasında birlikte değişimin varlığ 1 veya derecesini araştıran genel tarama modellerinden ilișkisel tarama modeli kullanılarak yapılmıştır (Karasar, 2011). Araştırma temelde değişkenler arasındaki ilişkiye odaklanmıștır. Araştırmanın hedeflerine ulaşabilmek ve oluşturulan hipotezleri deneyebilmek için değişkenler arasındaki nedensel ilişkiler tespit edilmeye çalışılmıştır. Bu araştırmanın bağımsız değişkeni E-İKY uygulamaları, bağımlı değişkeni E-İKY algılanan net fayda, aracı değişkeni ise E-İKY algılanan kullanım kolaylığıdır.

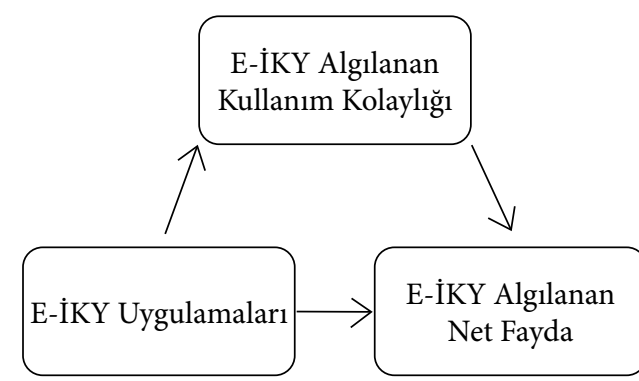

Sekil 1: Arastırma Modeli

\section{Literatür Taramas}

Elektronik hayat ilk olarak e-posta ile hayatımıza girmiştir. İlerleyen zamanda internetin gelişmesiyle e-banka, e-ticaret, e-devlet, e-arşiv, e-nabız ve yüzlerce "e"li uygulama hayatımızın her alanında karşımıza çıkmıştır. Yeni dünya düzeniyle beraber günlük hayatımızda sık kullandığımız birçok paradigma zaman, mekan ve sınır kavramı fark etmeksizin değişmiștir (Allahverdi, 2006). Elektro- 
nik insan kaynakları yönetimi, hizmet kuruluşlarının insan kaynakları hizmetlerinin kalitesini iyileştirmek için çağdaş kritik ihtiyaçlarına cevap verebilecekler yeni önemli yaklaşımlardan biri olmuştur (Ramezen vd.,2013). Gelişen bilgi teknolojileri ile İKY kendi kendine hizme verebilen ve intranet tabanlı özellikleriyle elektronik ortamda yer edinmiştir.

Elektronik insan kaynakları, son yıllarda teknoloji devinim hızının artışı ve küreselleşmeyle birlikte tüm dünyadak işletmeler ve çalışanlar üzerinde etkilerini artırmaktadır. Örgütler ise yeni pazarlara daha hızlı ulaşabilme, teknoloji ve bilginin getirdiği değişim dinamiklerin yakalama çabası içine girmiştir. Söz konusu değişimler, işletmelerin süreçlerin sürekli gözden geçirmelerini ve yeniliklere adapte olmalarını gerektirmektedir. $\mathrm{Bu}$ düzene ayak uyduramayan işletmeler, günümüz ekonomik düzeninden elenmeye mahkûmdur. Bu yüzden günümüzde birçok işletmenin elektronik insan kaynakları yönetimi üzerine çalışma yaptığ görülmektedir. Bu uygulamalar işletmeler için yeni kolaylıklar sağlarken, işletmelerin bilgi ve teknolojik donanımı bakımından yeterli düzeyde olup olmadığ hakkında da bilgi vermektedir. Bu işlem aynı zamanda işletmenin bel kemiğin oluşturan insan kaynağının ön planda tutulmasına olanak sağlamaktadır.

Elektronik insan kaynakları, insan kaynakları fonksiyonlarını uygulayabilmek için interaktif elektronik medyayı, telekomünikasyon ağlarını ve bilgisayar sistem- lerinin kullanılması şeklinde tanımlanır (Strohmeier, 2007). Son dönemde insan kaynakları fonksiyonları ve uygulamaları da güncel gelişmelerden payını almış ve İK başlığının altında E-İKY kendine yer bulmuştur. E-İKY “insan kaynakları stratejilerini, politikalarını ve uygulamalarını tamamen web-tabanlı kanallar üzerinden ya da doğrudan bu kanallardan destek alarak gerçekleştirme biçimidir" şeklinde tanımlanır (Saraç, 2016). E-IKKY aynı zamanda hem ağ oluşturma hem de en az iki bireysel veya kolektif aktörü ortak IK faaliyetlerini gerçekleştirirken desteklemek için bilgi teknolojisinin planlanması ve uygulanması olarak nitelendirilir (Strohmeier, 2007). Akademik literatürde E-İKY olarak bilinen kavram, pratikte daha çok E-IK olarak adlandırılır (Berber vd., 2018). Marler ve Fisher (2013), E-IKY yazınının bilgi teknolojileri, bilgi sistemleri veya strateji literatürüne kıyasla hala erken bir aşamada olduğunu söylemektedirler ve ilk E-İKY çalışmalarının 1995 civarında uluslararası yayında görünmeye başladığını ileri sürmüşlerdir (Winarto, 2018).

E-İKY faaliyetlerini gerçekleştirmek için bilgisayar donanımı, yazılım ve elektronik ağlardan (internet, intranet, extranet) yararlanır. Bu sayede kurumlar insan kaynaklarını elektronik ortamlara taşımış olur. Böylece personel yönetimi, insan kaynakları yönetimi, stratejik insan kaynakları yönetimi ve insan kaynakları bilgi sistemleri şeklinde devam eden insan kaynakları yönetimi; internet, bilgisayar ve teknolojinin gelişmesiyle yeni bir terim olan elektronik insan kaynakları yönetimi kavram ortaya çıkmıştır.

Lepak ve Snell (1998), Walker (2001), Lengninc-Hall ve Moritz (2003), Bissola ve Imperatori'nin (2013) E-IKKY üzerinde yaptıkları çalışmalar sonucunda E-İKY'nin üç farklı seviyede gerçekleştiğini belirtmektedirler. Bunlar; Operasyonel E-İKY, İlişkisel E-İKY ve Dönüşümsel E-İKY'dir. Operasyonel E-İKY uygulamaları, İK işlevinin idari rolü ile ilgilidir. Bunların İK işlevinin varlığı için zorunlu olduğu kabul edilir (Iqbal ve diğerleri, 2018). Bissolave Imperatori (2013) İlişkisel E-IKKY uygulamalarını "şirket dışında, organizasyon içinde ve çalışanlar arasındak ilişkiyi yönetmek için” bir araç olarak tanımlamaktadır. Kısaca kişiler veya kurumlar arasındaki ilişkiye odaklanmaktadır. Lepak ve Snell (1998)'e göre Dönüşümsel E-İKY, organizasyon için stratejik öneme sahip olan İKY alanındaki faaliyet lerin gerçekleştirilmesi ile ilgili olarak tanımlanmıştır. Bunlar; bilgi yönetimi stratejik yeniden uyum, çalışan gelişimi organizasyonunun stratejik hedefleri, stratejik yetkinlik yönetimi, stratejik yetenek yönetimi, sanal ekiplere destek, stratejik bilgi yönetimi, insan kaynakları stratejik uyumu vd. sayılabilir.

Günümüzde, İKY fonksiyonlarının örgüt içerisinde dijital formlara dönüştürülebildiği ve mevcut süreçlerle bütünleştiği görülmektedir. Günümüzde, en yaygın kullanılan E-IKKY işlevlerinin: e-planlama e-işe alım, e-özlük, e-performans yönetimi, e-eğitim, e-ücret yönetimi, e-kariyer yönetimi, e-endüstri ilişkileri, e-iş değerleme, e-iş̧̧i sağlığı, e-ödüllendirme ve e-izin olduğu belirtilmektedir. Teori ve uygulama bazında bakıldığında E-İKY fonksiyonlarından bazılarının örgütlerce çok fazla tercih edildiği bazılarının ise oldukça az kullanıldığı görülmektedir. Fonksiyonların sistemleri, elektronik ortamda kullanılmalarını etkilemektedir. Örneğin kurumlar e-işe alım sürecini elektronik ortamda sıklıkla kullanırken, e-insan kaynakları planlamasının kullanımı daha s1nırlı olabilmektedir (Doğan, 2011).

İnsan kaynakları uygulamalarının internet üzerinden kolayca yapılmasını sağlayan E-İK'nın üç ana kullanım alanı vardır. Kullanım alanları; bilgi paylaşı$\mathrm{m}$, otomasyon ve dönüşümdür. Bilgi paylaşımı, intranet sayesinde iş görenlere her türlü bilgi veya haberi hızlıca iletmesini sağlamaktadır. Otomasyon sistemleri, E-İK portalların kurulmasıla bordro, izin, kariyer, eğitim vb. işlemleri direkt olarak yapılabilmekte böylece İK'nın evrak yükü azalmaktadır. Dönüşüm ise kendisini İK'nın idari rolünün stratejik olarak değişmesinde gösterir. $\mathrm{Bu}$ değişimle beraber operasyonel işler azalmakta ve insan kaynakları işletmenin ana hedeflerine ulaşmasında stratejik bir rol üstlenmektedir. Dönüşüm ile beraber bazı sorunlar da ortaya çıkmıştır. Örneğin covid-19 virüsü sebebiyle evden çalışmanın artmasıyla E-İK uygulamalarının, ev ve iş arasındaki ince dengeyi bozduğu hakkındaki düşüncelerin ortaya çıkması veya çalıșanların özlük ve 
diğer bilgilerinin gizliliğinin sağlanmasindaki zorluklar sayılabilir (Vatansever ve Yllmaz, 2015). E-İKY, insan kaynakları süreçlerini otomatikleştirmek ve desteklemek için kullanılan web tabanlı bir araçtır (Iwu,2016).

\section{Veri Seti ve Yöntem}

3.1. Arastırmanın Problemi ve Kullanulan Hipotezler

Ülkemizde insan kaynakları konusunda literatürde çok fazla çalışmanın mevcut olduğu ancak elektronik insan kaynakları üzerine sınırlı sayıda çalışma bulunmakla birlikte bu sayının son yıllarda ufakta olsa artışta olduğu gözlemlenmektedir. Birbirinden bağımsız olarak birçok incelemeye konu olan algılanan kullanım kolaylığı ve algılanan net fayda kavramlarının elektronik insan kaynakları üzerindeki etkileri konusunda bir çalışmaya rastlanmamıştır. Bu çalışma, elektronik insan kaynaklar uygulamalarının işletmelerde var olan bilgi sistemleri ve teknolojileri belirlemek; kullanım seviyelerini tespit etmek, şirket, yönetici ve çalışan açısından elektronik insan kaynaklarının sağladığ avantajları belirlemek ve elektronik insan kaynakları uygulamaları ile ilgili memnuniyetlerini ölçmeyi hedeflemektedir. Belirlenen bireysel teknolojik hazır oluş düzeylerinin teknoloji kabulü kapsamında çalışanların E-IKKY uygulamalarını ne derecede kaliteli ve kullanımlarını kolay algıladıkları ölçülmeye çalışılmıştır. Araştırmada yanıtı aranan soru olarak, çalıșanların elektronik in- san kaynakları uygulamalarındaki bireysel teknolojik hazır oluş düzeylerinin ne durumda olduğu ve bu durumdan duydukları faydanın ne düzeyde olduğu belirlenmiştir.

Bu duruma göre belirlenen hipotezler

H1: E-IKKY uygulamaları, E-IKKY algılanan kullanım kolaylığını olumlu yönde etkiler.

H2: E-İKY uygulamaları, E-İKY alg1lanan net faydayı olumlu yönde etkiler.

H3: E-İKY uygulamaları, E-İKY alg1lanan kullanım kolaylığı yoluyla E-İKY algılanan net faydadan olumlu yönde etkilenir.

\subsection{Evren ve Örneklem}

Türkiye'de 2021 yılında 53 adet banka bulunmaktadır. Bunların içinden 13 banka ve 196 insan kaynakları çalışanına ulaşılmıştır. Bu bankalardan 8 tanesi mevduat bankası (QNB Finansbank, Yapı Kredi, Deniz Bank, Akbank, TEB, İş Bank, Şekerbank ve Garanti), 3 tanesi katılım bankası (Kuveyt Türk, Albaraka Türk ve Emlak Katılım), 1 tane kamu bankası (Vakıf Katılım) ve 1 tane de yatırım (Türkiye Sınai ve Kalkınma Bankası) bankası bulunmaktadır. İnsan kaynakları çalıșanları bu sistemlerin işleyişinden sorumlu olduğu için araştırma İK çalışanları ile gerçekleştirilmiştir. Araştırmanın örneklemi ise Türkiye'de faaliyet gösteren 13 bankanın insan kaynakları bölümünde karar verici konumunda görev yapan; direktör, müdür, yönetici, uzman ve uzman yardımcısı gibi unvanlarla çalı- şan 196 kişiyi kapsamaktadır. Örneklem olarak bankaların seçilmesinin sebebi değer yaratmak ve pazarda rekabet et mek için elektronik insan kaynaklar uygulamalarına odaklanmış ayrıca bu konu üzerine oldukça fazla yatırım(altyap1, eğitim vs.) yapmaları ve E-IKK kullanımının üst seviyede bulunmasıdır. $\mathrm{Bu}$ bilgiler neticesinde amaçlanan kurumsal performansı iyileştirmek, rakiplere üstünlük sağlamak ve E-IKKY gibi teknolojik yenilikleri benimseye yönlendirmektedir. Uygulama alanı içinden kolayda örnekleme yoluyla anketi doldurmay kabul eden kişiler seçilmiştir. Kullanılabilir düzeyde cevap veren herkesin anketi değerlendirmede kullanılmıştır.

Uygulama alanı olarak bu araştırmada Bankacıllk ve Finans sektöründe faaliyet gösteren, Türkiye'de aktif olarak hizmet veren bankaların İnsan Kaynakları Bölümündeki direktör, müdür yönetmen, uzman ve uzman yardımcis unvanlarıyla çalışan kişilerden elde edilen veriler kullanılmıştır.

$\mathrm{Bu}$ anketin uygulanması için kişi sayıs1 sinırlılığında ise Bankacılık ve Finans sektöründe faaliyet gösteren, Elektronik İnsan Kaynakları Yönetimi uygulamalarını kullanan bankaların, insan kaynakları bölümünde çalışan, elektronik in san kaynakları yönetimi uygulamaların kullanma yetkisi olan toplam 196 kişiye uygulanmıştır.

Ayrıca araştırmanın değişkenleri, E-IKKY uygulamaları, E-İKY uygulamalarında algılanan kullanım kolaylığı ve
E-İKY uygulamalarından algılanan net fayda şeklinde sıralanmaktadır. Bu değişkenler ile ilgili elde edilen veriler de analiz için kullanılmıştır.

\section{3. Ölçüm Aracı}

Hazırlanan anket formu toplam 22 soru ve dört bölüm halinde tasarlanmıştır. Anketin birinci bölümünde çalışanların elektronik insan kaynakları yönetimi uygulamalarına ait 11 soru sorulmuştur. Birinci bölüm kendi içinde 3'e ayrılmıştır. Bu bölümler: Operasyonel E-İK (3 soru), İlişkisel E-İK (5 soru) ve Dönüşümsel E-IKK (3 soru)'dır. Anketin ikinci bölümünde, E-İKY alg1lanan net fayda ölçeğinde, 6 soru sorulmuştur. Anketin üçüncü bölümünde, E-IKKY algılanan kullanım kolaylığı ölçeğinde, 5 soru sorulmuştur. Son bölümde ise işletme adı, sektör, cinsiyet, yaş, eğitim durumu, İK pozisyonu, sorumluluk alanı, işletmedeki çalışma süresi, E-IK kullanım süresi ve işletmedeki toplam çalışan sayısı ile ilgili demografik sorular bulunmaktadır. Anket formunda katılımcilardan sorulara beşli (5'li) Likert ölçeğinde; “kesinlikle katılmıyorum”, "katılmıyorum”, "kararsızım”, "katılıyorum”, "kesinlikle katılıyorum” şeklindeki seçeneklerden birini işaretlemesi suretiyle, okudukları yargılara ne ölçüde katılıp, katılmadıklarını belirtmeleri istenmiştir.

- Araştırmanın modeline uygun olarak; Elektronik İnsan Kaynakları düzeylerinin ölçülebilmesi için Iqbal ve diğ. (2019)tarafindan geliştirilen ve Operasyonel E-İK (3 soru), İlişkisel E-İK (5 soru) 
ve Dönüşümsel E-İK (3 soru) olmak üzere üç kategori ve 11 soruyla inceleyen “elektronik insan kaynakları uygulaması ölçeği” kullanılmıştır.

-Algılanan kullanım kolaylığının ölçmek için, F.Davis'in (1985) tarafindan geliştirilen 5 soruluk ölçek kullanılmıştir.

- Algılanan net faydayı ölçmek için, Tansley ve diğ. (2001) tarafından geliştirilen 6 soruluk ölçek kullanılmıştır.

- Demografik bilgi formu, araştırmac1 tarafindan oluşturulan bu formda katılımcılara cinsiyet, yaş, eğitim durumu, İK sorumluluk alanı, İK pozisyonu, işletmedeki çalışma süresi, E-İKY kullanım süresi, işletme adı, sektör ve işletmedeki toplam çalışan sayısına ilişkin 10 soru yöneltilmiştir.

\subsection{Verilerin Toplanması}

Araştırma kapsamında hazırlanan anket, Google formlarda elektronik forma dönüştürülmüsstür. Dijital ortamda oluşturulan anket formları e-posta, mesajlaşma uygulamaları ve sosyal medya platformları kullanılarak katılımcılara ulaştırılmıştır. Bunun yanı sıra internet yoluyla ulaşılamayan banka insan kaynakları çalışanlarına, anketler çıktı alınıp elden teslim edilmiştir. Ölçekleri cevaplamak yaklaşık 4 dakika sürmektedir. Online verilerin toplanması ise 8 ay sürmüştür.

\section{Verilerin Analizi}

Araştırma tutum ölçmeye yönelik olduğundan tutumlarla ilgili olarak ifadeleri 5'li Likert ölçeğinde değerlendirmeleri istenmiştir. Verilerin analizi SPSS 25 programında yapılmıştır. Yapılan analizler sırasıyla, tüm ölçekler için güvenilirlik ve faktör analizinin yanı sıra hipotezler doğrultusunda eldeki verilerin değerlendirilmesinde t-test, ANOVA ve Post Hoc, Pearson Korelasyon, Regresyon Analizi kullanılmıştır. Ölçeklerin güvenirliklerinin test edilmesinde cronbach alpha ve ayrica faktör analizleri kullanılmıştır. Sonuçlar \%95 güven aralığında ve 0,05 anlamlılık düzeyinde yorumlanmıştır.

Model içinde yer alan değişkenlerin, Granger nedensellik testinde durağanlık dereceleri aynı seviyede olması gerekmektedir. Toda Yamamoto nedensellik analizinde ise değişkenlerin aynı dereceden durağan olmalarına ihtiyaç yoktur. Ancak Toda Yamamoto analizi için değişkenlerin maksimum durağanlık düzeyinin tespit edilmesi gerekmektedir. Bu çalışmada durağanlık analizi için Genişletilmiş Dickey Fuller (ADF) durağanlık testi tercih edilmiştir.

\subsection{Demografik Bulgular}

Araştırmanın evrenini 18 yaş üstünde olan ve Türkiye'de ikamet eden bankaların insan kaynakları birimlerinde çalışan bireyler oluşturmaktadır. Çalışma grubunun ise araştırmaya katılmaya gönüllü olan 18 yaş üstü 121 kadın ve
75 erkek olmak üzere toplam 196 birey oluşturmaktadır. Katılımcıların demog rafik bilgileri Tablo 1'de gösterilmiştir.

Çalışmaya katılanların \%61.7'sini (n=121) kadın, \%38.3'ünü (n=75) erkek olmak üzere 196 birey oluşturmaktadır. Katılımcıların yaş aralığı18-55'tir. 25 ve altındaki yaş aralığındaki bireyler tüm katılımcıların \%13.8'ini ( $\mathrm{n}=27), 26-35$ yaş aralığındaki bireyler \%76.5'ini (n=150), 36-45 yaş aralığındaki bireyler \%8.2'sini $(\mathrm{n}=16), 46$ ve 55 yaş aralığındaki bireyler \%1.5'ini ( $\mathrm{n}=3$ ) oluşturmaktadır.

Katılımcıların eğitim durumu değişkeninin dağılımı ise şu şekilde gerçekleşmiştir: \%1.5 (n=3) katılımcı yüksekokul mezunu, \%64.8 ( $\mathrm{n}=127)$ katılımcı üniversite mezunu, \%32.1 ( $\mathrm{n}=63$ ) katılımcı yüksek lisans mezunu ve son olarak da \%1.5 $(\mathrm{n}=3)$ katılımcı doktora mezunu olarak tespit edilmiştir.

Toplam çalışma süreleri incelendiğinde;

Katılımciların \%65.8'i (n=129) 5 yıldan az süredir çalışmaktadır.

Katılımcıların \%27.0'si ( $\mathrm{n}=53)$ ise 5-10 yıl arası bir süredir çalışmaktadır

Katılımciların \%4.6's1 (n=9) 11-20 yıl arası bir süredir çalışmaktadır ve son olarak katılımcıların \%2.6'sı (n=5) 21-30 yıl arasında bir süredir çalışmaktadır.

Çalışma grubunun Elektronik İKY sistemi kullanma sürelerine ilişkin dağılı$\mathrm{m}$ ise şu şekilde gerçekleşmiştir:
$\% 12.8(\mathrm{n}=25)$ katılımc1 1 yıl ve daha az bir süredir,

$\% 10.2$ (n=20) katılımcı 2 yıldır,

$\% 18.4$ (n=36) katılımcı 3 yıldır,

\%7.1 (n=14) katılımc1 4 yıldır,

\%38.3 (n=75) katılımcı 5 yıldır,

$\% 6.1(\mathrm{n}=12) 6$ yıldır ve son olarak \%7.1 (n=14) katılımcı 7 yıldan fazla bir süredir Elektronik İKY sistemi kullanmaktadır. 


\begin{tabular}{|c|c|c|c|c|}
\hline & & Siklık & Geçerli Yüzde & Toplamsal Yüzde \\
\hline \multirow{2}{*}{ Cinsiyet } & Kadın & 121 & 61,7 & 61,7 \\
\hline & Erkek & 75 & 38,3 & 100,0 \\
\hline \multirow{4}{*}{ Yaş } & 25 ve alt & 27 & 13,8 & 13,8 \\
\hline & $26-35$ & 150 & 76,5 & 90,3 \\
\hline & $36-45$ & 16 & 8,2 & 98,5 \\
\hline & $46-55$ & 3 & 1,5 & 100,0 \\
\hline \multirow{4}{*}{ Eğitim Durumu } & Yüksek Okul & 3 & 1,5 & 1,5 \\
\hline & Üniversite & 127 & 64,8 & 66,3 \\
\hline & Yüksek Lisans & 63 & 32,1 & 98,5 \\
\hline & Doktora & 3 & 1,5 & 100,0 \\
\hline \multirow{4}{*}{ Toplam çalışma süresi } & 5 yıldan az & 129 & 65,8 & 65,8 \\
\hline & $5-10$ yil aras1 & 53 & 27,0 & 92,9 \\
\hline & $11-20 \mathrm{yıl}$ arası & 9 & 4,6 & 97,4 \\
\hline & $21-30$ yıl arası & 5 & 2,6 & 100,0 \\
\hline \multirow{8}{*}{$\begin{array}{l}\text { Elektronik IKYY sistemi } \\
\text { kullanma süresi }\end{array}$} & 1 yil ve daha az & 25 & 12,8 & 12,8 \\
\hline & 2 yil & 20 & 10,2 & 23,0 \\
\hline & 3 yil & 36 & 18,4 & 41,3 \\
\hline & $4 \mathrm{yll}$ & 14 & 7,1 & 48,5 \\
\hline & 5 yil & 75 & 38,3 & 86,7 \\
\hline & $6 \mathrm{yll}$ & 12 & 6,1 & 92,9 \\
\hline & 7 yildan fazla & 14 & 7,1 & 100,0 \\
\hline & Toplam & 196 & 100,0 & \\
\hline
\end{tabular}

Tablo 1: Anketi Cevaplayanlar ile İlgili Özet İstatistikler
4.2. Faktör Analizi ve Güvenilirlik Test Sonuçları

Faktör analizi, çok sayıda değişkeni daha az sayıda faktöre indirgemek için kullanılan bir tekniktir. Bu teknik, tüm değişkenlerden maksimum ortak varyansı çıkarmakta ve bunları ortak bir puana koymaktadır (Gorsuch, 1983). Faktör analizi ile en iyi çözüm, minimum hassasiyet kaybıyla verilerinizin gerçek doğasını temsil eden bir basitleştirme sağlayan çözümdür. Faktör analizine bazen "boyut küçültme” de denir. Verilerin "boyutlarını”, gözlemlenmeyen değişkenler veya gizli değişkenler olarak da bilinen bir veya daha fazla "süper değişkene" indirgeyebilmektedir. Faktör analizi tek bir teknik değildir, gözlemlenebilir değişkenleri yönlendiren gizli faktörleri tanımlamak için kullanılabilecek bir istatistiksel yöntemler bütünüdür (Bryant ve Yarnold, 1995).

Kullanılan ölçeklerin katılımcılar tarafindan kaç farklı boyutta ve ne düzeyde algılandığını, öngörülen faktör yapısına yüklenip yüklenmediğini tespit etmek amaciyla keşifsel faktör analizi uygulanmıştır. Keşifsel faktör analizi uy gulamasında SPSS 25paket programı üzerinden "Temel bileșenler analizi" ve "Promax" döndürme yöntemi kullanılmıştır. Temel bileşenler analizi yöntemi çok boyutlu ölçeklerin alt boyutlarını indirgemek amacıyla kullanılmaktadır (Jolliffe, 2002). Bu yöntem sonucunda boyutların indirgenmesi ile elde edilen temel bileşenler çalışmanın amacı doğrultusunda yapılacak analizlerde belirleyici olarak yer alabilmektedir (Rourke ve Hatcher, 2013). Promax döndürme yöntemi ise birbiri ile ilişkili basit yapıları meydana çıkarması ve hızlı olması nedeniyle sosyal bilimler alanında en çok tercih edilen döndürme tekniğidir. Değişkenler arasındaki ilişsi düzeyinin yüksek olması durumunda başvurulması önerildiği için bu çalışmada da kullanılmıştır (Büyüköztürk, Şekercioğlu ve Çokluk, 2010).

Faktör analizi öncesinde veri setinin faktör analizine uygunluğuna bakmak amacıyla Kaiser-Meyer-Olkin (KMO) örneklem yeterliliği testi ve Bartlett küresellik testi uygulanmıştır. Kaiser-Meyer-Olkin (KMO) testi ile örneklemlerden elde edilen veri yapısının faktör analizi için uygunluğu tespit edilmektedir. KMO değerinin 0,60 ve üzerinde olması veri yapısının faktör analizi için uygun olduğunu göstermektedir. Korelasyon matrisinde yer alan ilişkilerin faktör analizi uygulaması için uygun olup olmadığ Bartlett Küresellik testi ile sınanmaktadır. Bu test sonucunda $\mathrm{p}$ değerinin 0,05 'ten küçük olması örneklem için faktör analizi uygulanabileceği anlamına gelmektedir (Gürbüz ve Şahin, 2016). Faktör analizi sonuçları Tablo 2'de yer almaktadır.

Keşifsel faktör analizinin sonucunda ortaya çıkan faktör yükleri ve "Communality” değerleri için alt sınırın 0.5 olduğu kabul edilmiştir (Hair vd., 2010). Buna göre faktör yükü ve communality değeri 0.5 ten düşün olan; teorik olarak öngörülen faktör yapısına yüklenmeyen değişkenler faktör yapısını bozmayacak şekilde değer- 
lendirmeye alınmamaktadır (Field, 2005). Bu bağlamda E-İKY Uygulamaları ölçeği İlişkisel E-İKY alt boyutuna ait birinci soru (İlişkisel EIKY 1) kapsam dışı bırakılmıştır. Böylelikle toplam yirmi iki maddeden bir tanesi çıkarılmış ve yirmi bir madde üzerinden analize devam edilmiştir.

\begin{tabular}{|c|c|c|c|c|c|}
\hline & $\begin{array}{c}\text { E- İKY } \\
\text { Alglanan } \\
\text { Fayda }\end{array}$ & $\begin{array}{c}\text { E- ÍKY } \\
\text { Kullanışhlı̆̆g }\end{array}$ & $\begin{array}{l}\text { İlişkisel } \\
\text { E-IKKY }\end{array}$ & $\begin{array}{c}\text { Dönüşümsel } \\
\text { E-ÍKY }\end{array}$ & $\begin{array}{c}\text { Operasyonel } \\
\text { E-İKY }\end{array}$ \\
\hline Algilanan Fayda 2 & 0,960 & & & & \\
\hline Algilanan Fayda 5 & 0,955 & & & & \\
\hline Algilanan Fayda 3 & 0,893 & & & & \\
\hline Algilanan Fayda 4 & 0,862 & & & & \\
\hline Algilanan Fayda 6 & 0,845 & & & & \\
\hline Algılanan Fayda 1 & 0,787 & & & & \\
\hline Kullanım Kolaylığı 5 & & 0,905 & & & \\
\hline Kullanım Kolaylığı 1 & & 0,902 & & & \\
\hline Kullanım Kolaylığı 4 & & 0,814 & & & \\
\hline Kullanım Kolaylığı 2 & & 0,647 & & & \\
\hline Kullanım Kolaylığı 3 & & 0,628 & & & \\
\hline İlişkisel EIKY 2 & & & 0,939 & & \\
\hline Ílişkisel EIKY 4 & & & 0,794 & & \\
\hline İlişkisel EIKY 3 & & & 0,719 & & \\
\hline flișkisel EIKY 5 & & & 0,669 & & \\
\hline Dönüşümsel EIKY 2 & & & & 0,963 & \\
\hline Dönüşümsel EIKY 1 & & & & 0,905 & \\
\hline Dönüşümsel EIKY 3 & & & & 0,626 & \\
\hline Operasyonel EIKY 1 & & & & & 0,875 \\
\hline
\end{tabular}

Tablo 2: Faktör Analizi Sonuçları

\begin{tabular}{|l|c|c|c|c|c|}
\hline Operasyonel EIKY 3 & & & & & 0,831 \\
\hline Operasyonel EIKY 2 & & & & & 0,622 \\
\hline \% Varyans Açılayıcılığı & 46,882 & 10,891 & 8,337 & 5,598 & 5,000 \\
\hline Notlar & $\begin{array}{l}\text { (i) Promax Rotasyonlu Temel Bileşenler Analizi uygulanmıs̆tr. } \\
\text { (ii) Toplam Açıklanan Varyans: \%76,708; KMO: 0,906; Bartlett } \\
\text { 3211,033*** }\end{array}$ \\
\hline
\end{tabular}

Tüm ölçek soruları için yapılan faktör analizi sonuçlarında KMO test değerinin 0,60'tan yüksek çıkması örneklemin faktör analizi uygulanması için uygun olduğunu, Bartlett Küresellik Testi'nde $\mathrm{p}$ değerinin 0,05'ten düşük çıkması da faktör analizi kullanımının uygun olduğunu göstermektedir.

Oluşan faktör yapılarının E- İKY Algılanan Faydanın\%46,88'ini, E- İKY Kullanışlılığının \%10,89'unu, İlişkisel E-İKY’nin\%8,33'ünü, Dönüşümsel E-İKY'nin \%5,59'unu ve Operasyonel E-IKY'nin\%5,00'ini açıkladığı belirlenmiştir. Oluşturulan faktör yapıları toplam $\% 76,70$ oranında açılklamaktadır.

Araştırmada kullanılan ölçeklerin ve alt boyutların iç tutarlılık katsayısı güvenirlik analizi Cronbach Alpha istatistiksel yöntemi ile incelenmiştir. Güvenilirlik analizi sonuçlarında Cronbach Alpha değeri Operasyonel E-İKY boyutu için 0,792, İlişkisel E-İKY boyutu için 0,873, Dönüşümsel E-İKY boyutu için 0,840, E- İKY Algılanan Fayda boyutu için ise 0,944, E- İKY Kullanışlılığ için 0,901 olarak çıkmıştır (Tablo 3). Çıkan Cronbach Alpha değerleri ölçekteki maddeler arasında iç tutarlılık kabul edilebilir alt sınır değeri olan 0.70’ten yüksektir.

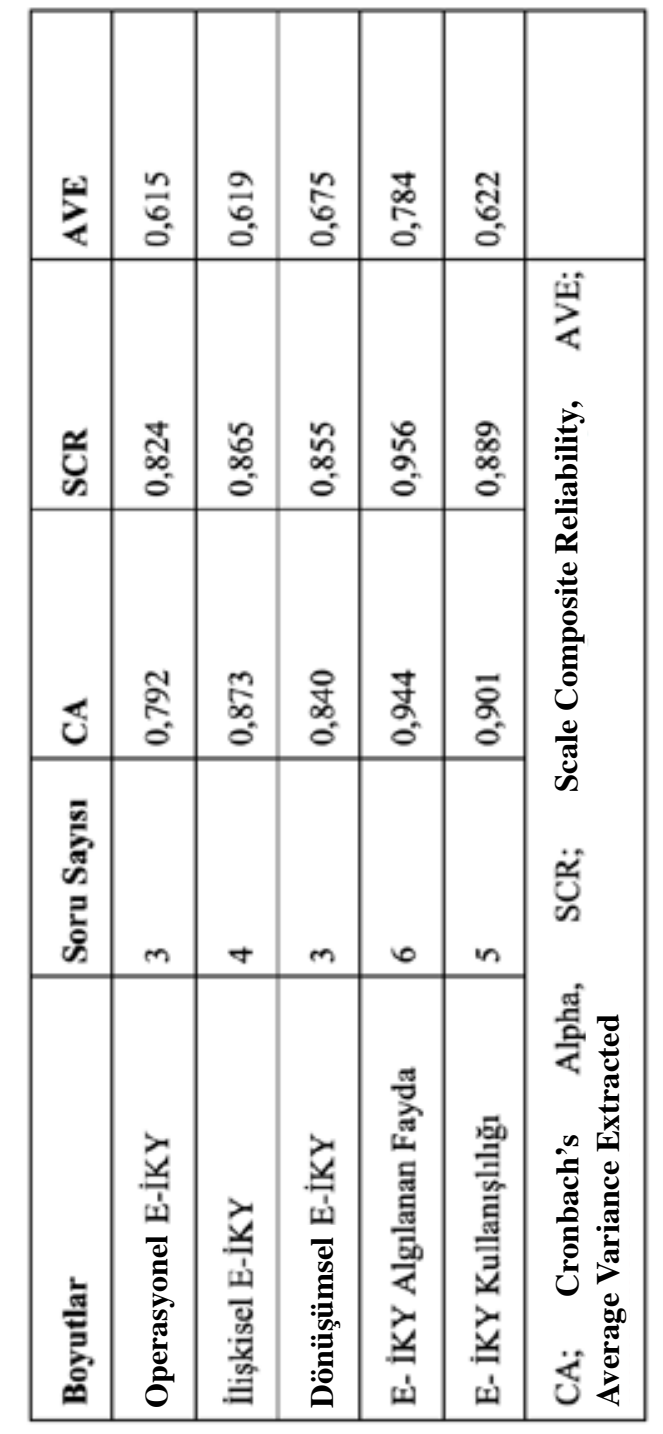

Tablo 3: Geçerlilik ve Güvenilirlik Değerleri 
4.3. Ölçeklere İlişkin Tanımlayıcı İstatistikler ve Korelasyon Analizi Sonuçlar

Operasyonel E-İKY, İlişskisel E-İKY, Dönüşümsel E-İKY, E- İKY Algılanan Fayda ve E- İKY Kullanışlılığı ölçekleri ile ilgili betimsel istatistiklere ve korelasyon analizlerine Tablo 4'te yer verilmiștir.

E-İKY Uygulamaları ölçeği Operasyonel E-İKY, İlişkisel E-İKY, Dönüşümsel E-İKY alt boyutları ile E- İKY Algılanan Fayda, E- İKY Kullanım Kolaylığı ölçekleri anlamlı korelasyonlar göstermektedir. Operasyonel E-İKY ile İlişkisel E-İKY ( $\mathrm{r}=.358)$, Dönüşümsel E-İKY(r=.434), E- İKY Algilanan Fayda(r=.466), E- İKY Kullanım Kolaylığı (r=.532)arasında pozitif yönde bir ilişki vardır.

\begin{tabular}{|c|c|c|c|c|c|c|c|}
\hline Değişken & Ortalama & Std. Hata & 1 & 2 & 3 & 4 & 5 \\
\hline Operasyonel E-İKY & 3,944 & 0,599 & 1 & & & & \\
\hline İlişkisel E-İKY & 4,112 & 0,709 &, $358^{* *}$ & 1 & & & \\
\hline Dönüşüumsel E-İKY & 3,939 & 0,811 &, $434^{* *}$ &, $642^{* *}$ & 1 & & \\
\hline E- IKY Algılanan Fayda & 4,062 & 0,782 &, $466^{*}$ &, $559^{*}$ &, $490^{*}$ & 1 & \\
\hline E- İKY Kullanışlılığ & 4,057 & 0,679 &, $532^{* *}$ &, $409^{* *}$ &, $430^{* *}$ & ,673** & 1 \\
\hline
\end{tabular}

Köşegen değerleri AVE değerinin kareköküdür.

${ }^{*} \mathrm{p}<0.05,{ }^{* *} \mathrm{p}<0.01$ (2-tailed).

Tablo 4: Ortalamalar, Standart Hatalar ve Değişkenler Arası Korelasyon Değerleri

Tablo 4'te görüldüğü gibi bireylerin E-İKY Uygulamaları Ölçeğinin Operasyonel E-İKY alt boyutundan aldığ1 toplam puan ortalaması $3.94( \pm 0.59)$,

İlişkisel E-İKY alt boyutundan aldığ toplam puan ortalamas1 $4.11( \pm 0.70)$ ve

Dönüşümsel E-IKKY alt boyutundan aldığı toplam puan ortalaması $3.93( \pm 0.81)$ olarak tespit edilmiştir.

Katılımcıların E- İKY Algılanan Fayda Ölçeğinden aldığı toplam puan ortalamas1 4.06 ( \pm 0.78$)$, E- İKY Kullanım Kolaylığ Ölçeğinden aldığı toplam puan ortalaması 4.05 ( \pm 0.67$)$ şeklinde bulunmuştur.
İlișkisel E-İKY ile Dönüșümsel E-İK$\mathrm{Y}(\mathrm{r}=.642)$, E-İKY Algilanan Fayda( $\mathrm{r}=.559)$, E- İKY Kullanım Kolaylığı (r=.409) arasında pozitif yönde bir ilişki vardır. Dönüşümsel E-İKY ile E-İKY Algılanan Fayda ( $\mathrm{r}=.490)$, E-İKY Kullanım Kolaylığ $1(\mathrm{r}=.430)$ arasında pozitif yönde bir ilişki vardır. E-İKY Algılanan Fayda ile E-İKY Kullanım Kolaylığı ( $\mathrm{r}=.673)$ arasında pozitif yönde bir ilişki vardır.

4.4. Aracı Etkileri Belirlemek Üzere Uygulanan Regresyon Sonuçları

E-İKY Uygulamaları (ilişkisel, dönüşümsel ve operasyonel) ile E-İKY Algılanan Fay- da arasındaki ilişkide E-IKKY Kullanım Kolaylığı aracı değişken rolünün incelenmes amacıyla regresyon analizi uygulanmıștır. Bağımlı değişken ile bağımsız değişkenler arasındaki neden-sonuç ilişkisini araştıran, değişkenler arasındaki ilişkiyi bir model ile açıklayan analize regresyon analiz denmektedir (Gürbüz ve Şahin, 2016).

Çalışmada;

$\mathrm{X}=$ Bağımsız değişken, $\mathrm{Y}=$ =Bağımlı değişken, $\mathrm{M}=\mathrm{Arac}$ değişken

$\mathrm{a}=X$ 'in M üzerine etkisi,

$\mathrm{b}=\mathrm{M}$ 'nin $\mathrm{Y}$ üzerine etkisi

$\mathrm{ab}=$ Dolaylı Etki

c'=Doğrudan Etki olarak alınmıștır.

Aracılık etkisini incelerken, Boostrap yöntemi ile Regresyon analizi ve sobel testi kullanılmıştır. Boostrap, var olan veri setinin yer değiştirme yöntemi arac1lığıyla defalarca (örneğin 1000, 2000, $5000 \mathrm{kez}$ ) yeniden örnekleme sistemine dayanan, her yeni örnekleme için aracılık etkisinin hesaplandığı bir yöntemdir (Preacher ve Hayes, 2008).

Yordayıcı değişken olarak E-İKY Uygulamaları (ilişkisel, dönüşümsel, ope rasyonel) alt boyutlarından alınan toplam puanlar alınmıştır. E-İKY Algılanan Fayda ölçeğinden elde edilen puanlar araştırmanın yordanan değişkenleridir. E-İKY Kullanım Kolaylığı ölçeğinden alınan toplam puanlar ise ileri sürülen arac1 (mediator) değişkendir. E-İKY Kullanım Kolaylığı ölçeğinin aracı değişken rolünü incelemek amacıyla her bir analizde, bağımsız değişkenin beta değerlerindeki farka ve aracı değişken ve bağımlı değişken arasındaki ilişkinin anlamlılığına bakılmıștır. (Kenny ve ark., 1998).

Araştırma modelinde Baron ve Kenny'nin (1986) belirlemiş olduğu aracı değişken koşulları dikkate alınmıştır. Bir değişkenin aracı değişken olarak kabul edilebilmesi için karşılaması gereken 4 koşul bulunmaktadır.

Bu koşullar:

1.Yordayıcı değişkenler ve yordanan değişkenler arasındaki ilişki anlamlı olmalıdır.

2.Yordayıcı değişkenler ve aracı değişkenler arasında anlamlı bir ilişki olmalıdır.

3.Yordanan değişken ile aracı değişken arasında anlamlı bir ilişki olmalıdır.

4. Aracı değişkenler ile yordayıcı değişkenlerin regresyon analizinde yordayıcı değişkenler ve yordanan değişkenler arasında var olan anlamlı ilişkinin anlamlılığı ortadan kalkmalı veya anlamlılık düzeyi azalmalıdır. Tam aracı rolünden bahsedebilmek için aracı değişken modele girdiğinde yordayıcı değişken ile yordanan değişken arasındaki ilişki anlamlı olmaktan çıkmalıdır. Yordayıcı ve yordanan değişken arasındaki ilişkinin anlamlılık düzeyinde azalma söz konusu olduğunda ise kısmi aracılık rolünden söz edilebilmektedir (Baron ve Kenny, 1986).

Baron ve Kenny'nin (1986) ilk üç ölçütünün araştırma değişkenleri açısından kar- 
şılanıp karşılanmadığının belirlenebilmesi amacıyla E-İKY Uygulamaları (ilişkisel, dönüşümsel, operasyonel), E-İKY Algilanan Fayda ve E-İKY Kullanım Kolaylığı arasındaki korelasyon katsayılarına bakılmıştır sonrasında regresyon analizi yapilmıştır. İlgili değişkenlerle ilgili korelasyon analizleri Tablo 4'te yer almaktadır. Sonuçlar \%95 güven aralığında incelenmiştir.

Dönüşümsel E-İKY Uygulamalarının E-İKY Algılanan Net Fayda yı ne ölçüde yordadığının ve E-İKY Kullanım Kolaylığının aracı rol oynayıp oynamadığının araştırılması amacıyla yapılan analiz sonuçları Tablo 5’te verilmiştir.

\begin{tabular}{|c|c|c|c|c|c|c|c|c|c|}
\hline $\begin{array}{c}\text { Bağımsız } \\
\text { Değişken (ler) }\end{array}$ & Bağımlı Değişken & $ß$ & SE & $t$-test & $\mathbf{p}$ & \multicolumn{2}{|c|}{$\begin{array}{l}\text { 95\% Güven } \\
\text { Aralığı }\end{array}$} & \multirow{2}{*}{\begin{tabular}{|l} 
F-test \\
61,264
\end{tabular}} & \multirow{2}{*}{\begin{tabular}{|c|} 
R2 \\
0,240 \\
\end{tabular}} \\
\hline $\begin{array}{l}\text { Dönüşümsel } \\
\text { E-İKY }\end{array}$ & $\begin{array}{l}\text { E- İKY Algilanan } \\
\text { Fayda }\end{array}$ & 0,472 & 0,060 & 7,827 & 0,000 & 0,353 & 0,591 & & \\
\hline $\begin{array}{l}\text { Dönüşümsel } \\
\text { E-İKY }\end{array}$ & \begin{tabular}{|l|l|l} 
E- IKYY \\
Kullanışılı̀̆ı̆ı
\end{tabular} & 0,360 & 0,054 & 6,641 & 0,000 & 0,253 & 0,467 & 44,101 & 0,185 \\
\hline $\begin{array}{l}\text { Dönüşümsel } \\
\text { E-IKKY }\end{array}$ & \multirow{2}{*}{$\begin{array}{l}\text { E- ÍKY Algilanan } \\
\text { Fayda }\end{array}$} & 0,237 & 0,054 & 4,370 & 0,000 & 0,130 & 0,344 & \multirow{2}{*}{97,138} & \multirow{2}{*}{0,501} \\
\hline $\begin{array}{l}\text { E- İKY } \\
\text { Kullanışlılığı }\end{array}$ & & 0,653 & 0,065 & 10,066 & 0,000 & 0,525 & 0,780 & & \\
\hline \multicolumn{10}{|l|}{ Etkiler } \\
\hline \multicolumn{2}{|l|}{ Doğrudan Etki } & 0,237 & 0,054 & 4,370 & 0,000 & 0,130 & 0,344 & - & - \\
\hline \multicolumn{2}{|l|}{ Dolaylı Etki } & 0,235 & 0,060 & 5,901 & 0,000 & 0,131 & 0,368 & - & - \\
\hline \multicolumn{2}{|l|}{ Toplam Etki } & 0,472 & 0,060 & 7,827 & 0,000 & 0,353 & 0,591 & - & -- \\
\hline \multicolumn{10}{|c|}{$\begin{array}{l}\text { Değerler } 5000 \text { örneklem düzeyinde bootstrap sonuçlarından elde edilmiştir. Dolaylı etkinin t değeri } \\
\text { ve p değeri sobel testi ile hesaplanmıştır. }\end{array}$} \\
\hline
\end{tabular}

Dönüşümsel E-İKY Uygulamalarının E-İKY Kullanım Kolaylığı ile (a yolu; $ß$ $=0.360 \mathrm{SE}=.054, \mathrm{t}=6.641, \mathrm{p} ß .001,95 \% \mathrm{CI}$ [0.253, 0.467]) pozitif ve anlamlı bir ilişki içinde olduğu bulunmuştur. Bu ilişkinin devamında E-İKY Kullanım Kolaylığı ile E-İKY Algılanan Net Fayda arasındaki ilişki de anlamlı ve pozitif olarak bulunmuştur $(\mathrm{b}$ yolu, $ß=0.653, \mathrm{SE}=.065, \mathrm{t}=10.066, \mathrm{p}$ ß .001, 95\% CI [0.523, 0.780]). Dönüşümsel E-İKY Uygulamaları ile E-İKY Algılanan Net Fayda arasındaki doğrudan etki (c' yolu; $\beta$ $=0.237, \mathrm{SE}=.054, \mathrm{t}=4.370, \mathrm{p} ß .001,95 \% \mathrm{CI}$ $[0.130,0.344])$ anlamlı bulunmuştur.

\begin{tabular}{|c|c|c|c|c|c|c|c|c|c|}
\hline $\begin{array}{c}\text { Bağımsız } \\
\text { Değişken(ler) }\end{array}$ & $\begin{array}{c}\text { Bağımlı } \\
\text { Değişken }\end{array}$ & B & SE & t-test & $\mathbf{p}$ & \multicolumn{2}{|c|}{$\begin{array}{c}\text { 95\% Güven } \\
\text { Aralığı }\end{array}$} & \multirow{2}{*}{$\begin{array}{l}\text { F-test } \\
88,258\end{array}$} & \multirow{2}{*}{\begin{tabular}{|c|} 
R2 \\
0,313 \\
\end{tabular}} \\
\hline İlişkisel E-IKKY & $\begin{array}{l}\text { E- IKY } \\
\text { Algilanan Fayda }\end{array}$ & 0,617 & 0,066 & 9,395 & 0,000 & 0,487 & 0,746 & & \\
\hline İlişkisel E-İKY & $\begin{array}{l}\text { E-İKY } \\
\text { Kullanışllığ1 }\end{array}$ & 0,392 & 0,063 & 6,249 & 0,000 & 0,268 & 0,516 & 39,056 & 0,168 \\
\hline Îlişkisel E-İKY & \multirow{2}{*}{$\begin{array}{l}\text { E- ÍKY } \\
\text { Algilanan Fayda }\end{array}$} & 0,376 & 0,058 & 6,437 & 0,000 & 0,261 & 0,491 & \multirow[b]{2}{*}{117,532} & \multirow[b]{2}{*}{0,549} \\
\hline $\begin{array}{l}\text { E-ÍKY } \\
\text { Kullanışllı̆ı̆ı }\end{array}$ & & 0,614 & 0,061 & 10,061 & 0,000 & 0,493 & 0,734 & & \\
\hline \multicolumn{2}{|l|}{ Etkiler } & & & & & & & & \\
\hline Doğrudan Etki & & 0,376 & 0,058 & 6,437 & 0,000 & 0,261 & 0,491 & -- & $\cdots$ \\
\hline Dolaylı Etki & & 0,241 & 0,067 & 5,587 & 0,000 & 0,117 & 0,380 & -- & $\cdots$ \\
\hline Toplam Etki & & 0,617 & 0,066 & 9,395 & 0,000 & 0,487 & 0,746 & -- & $\ldots$ \\
\hline
\end{tabular}

Değerler 5000 örneklem dūzeyinde bootstrap sonuçlarından elde edilmiştir. Dolaylı etkinin $\mathrm{t}$ değeri ve $\mathrm{p}$ değeri sobel testi ile hesaplanmıştr.

${ }^{*} \mathrm{p}<0.05,{ }^{* *} \mathrm{p}<0.01,{ }^{* * *} \mathrm{p}<0.001$

Tablo 6: İlişkisel E-İKY Regresyon ve Aracılık Etki Değerleri

Dönüşümsel E-İKY Uygulamaları ile Kullanım Kolaylığı arasındaki ilişkiye E-IKKY Algılanan Net Fayda arasındaki ilişkide E-İKY Kullanım Kolaylığı aracılığıyla dolaylı etkisi ( $\mathrm{ab}$ yolu; $\beta=0.235, \mathrm{SE}=.060$, $\mathrm{t}=5.901, \mathrm{p} ß .001,95 \% \mathrm{CI}[0.131,0.368])$ istatistiksel açıdan anlamlı bulunmuştur.

Toplam etkinin ise pozitif ve anlaml olduğu görülmektedir (c yolu; $ß=0.472$, $\mathrm{SE}=.060, \mathrm{t}=7.827, \mathrm{p} ß .001,95 \% \mathrm{CI}[0.353$, 0.591]). Sonuç olarak, önerilen model istatistiki olarak anlamlı çıkmıştır [F(1, 195) $=97.138, \mathrm{p}<.001, \mathrm{R} 2=.51]$ ve toplam varyansın \%5'ini açıkladığı tespit edilmiştir. Buna göre E-İKY Kullanım Kolaylığı, Dönüşümsel E-İKY Uygulamaları ile E-İKY kısmi aracılık etmektedir. İlişkisel E-İKY Uygulamalarının E-İKY Algılanan Net Faydayı ne ölçüde yordadığının ve E-İKY Kullanım Kolaylığının aracı rol oynayıp oynamadığının araştırılması amacıyla yapılan analiz sonuçları Tablo 6'da verilmiştir. 


\begin{tabular}{|c|c|c|c|c|c|c|c|c|c|}
\hline $\begin{array}{c}\text { Bağımsız } \\
\text { Değişken (ler) }\end{array}$ & $\begin{array}{c}\text { Bağımlı } \\
\text { Değişken }\end{array}$ & $\beta$ & SE & $t$-test & $\mathbf{p}$ & \multicolumn{2}{|c|}{$\begin{array}{l}95 \% \text { Güven } \\
\text { Aralığı }\end{array}$} & \multirow{2}{*}{$\begin{array}{l}\text { F-test } \\
53,765\end{array}$} & \multirow{2}{*}{$\begin{array}{r}\text { R2 } \\
0,217\end{array}$} \\
\hline $\begin{array}{l}\text { Operasyonel } \\
\text { E-IKKY }\end{array}$ & \begin{tabular}{|l|} 
E-ÍKY \\
Algılanan \\
Fayda
\end{tabular} & 0,608 & 0,083 & 7,333 & 0,000 & 0,444 & 0,771 & & \\
\hline $\begin{array}{l}\text { Operasyonel } \\
\text { E-IKY }\end{array}$ & $\begin{array}{l}\text { E-IKKY } \\
\text { Kullanıșlılığ1 }\end{array}$ & 0,603 & 0,069 & 8,749 & 0,000 & 0,467 & 0,739 & 76,540 & 0,283 \\
\hline $\begin{array}{l}\text { Operasyonel } \\
\text { E-IKY }\end{array}$ & \multirow{2}{*}{$\begin{array}{l}\text { E-IKY } \\
\text { Algilanan } \\
\text { Fayda }\end{array}$} & 0,197 & 0,081 & 2,433 & 0,016 & 0,037 & 0,356 & \multirow{2}{*}{85,106} & \multirow{2}{*}{0,469} \\
\hline $\begin{array}{l}\text { E-IKY } \\
\text { Kullanışlılığı }\end{array}$ & & 0,682 & 0,071 & 9,560 & 0,000 & 0,541 & 0,823 & & \\
\hline \multicolumn{2}{|l|}{ Etkiler } & & & & & & & & \\
\hline \multicolumn{2}{|l|}{ Doğrudan Etki } & 0,197 & 0,081 & 2,433 & 0,016 & 0,037 & 0,356 & $--\cdot$ & 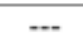 \\
\hline \multicolumn{2}{|l|}{ Dolaylı Etki } & 0,411 & 0,092 & 6,344 & 0,000 & 0,234 & 0,595 & -- & $\cdots$ \\
\hline \multicolumn{2}{|l|}{ Toplam Etki } & 0,608 & 0,083 & 7,333 & 0,000 & 0,444 & 0,771 & $\ldots$ & $\ldots$ \\
\hline \multicolumn{10}{|c|}{$\begin{array}{l}\text { Değerler } 5000 \text { örneklem düzeyinde bootstrap sonuçlarından elde edilmiştir. Dolaylı etkinin t değeri } \\
\text { ve p değeri sobel testi ile hesaplanmıştr. }\end{array}$} \\
\hline
\end{tabular}

İlişkisel E-İKY Uygulamalarının E-IKY lunmuştur. İlişkisel E-İKY Uygulamaları ile Kullanım Kolaylı̆̆ ile (a yolu; $\beta=0.392 \mathrm{SE}=\quad$ E-IKY Algilanan Net Fayda arasındaki ilis$.063, \mathrm{t}=6.249, \mathrm{p} ß .001,95 \% \mathrm{CI}[0.268,0.516]) \quad$ kide E-iKY Kullanım Kolaylı̆̆ aracılı̆̆ılya pozitif ve anlamlı bir ilişki içinde olduğu dolaylı etkisi ( $\mathrm{ab}$ yolu; $\beta=0.241, \mathrm{SE}=.067$, bulunmustur. Bu iliskinin devamında E-IKY $\quad \mathrm{t}=5.587, \mathrm{p} ß .001,95 \% \mathrm{CI}[0.117,0.380])$ istaKullanım Kolaylı̆̆ı ile E-IKKY Algılanan Net tistiksel açıdan anlamlı bulunmuştur. TopFayda arasındaki ilişki de anlamlı ve pozi- lam etkinin ise pozitif ve anlamlı olduğu tif olarak bulunmustur (b yolu, $\beta=0.614$, görülmektedir (c yolu; $\beta=0.617, \mathrm{SE}=066$, $\mathrm{SE}=.061, \mathrm{t}=10.061, \mathrm{p} ß .001,95 \% \mathrm{CI}[0.493, \mathrm{t}=9.395, \mathrm{p} ß .001,95 \% \mathrm{CI}[0.487,0.746])$.

0.734]). İlişkisel E-İKY Uygulamaları ile E-IKYY Algılanan Net Fayda arasındaki doğrudan etki (c' yolu; $ß=0.376, \mathrm{SE}=058, \mathrm{t}=6.437$, $\mathrm{p}$ ß .001, 95\% CI [0.261, 0.491]) anlamlı bu-

Tablo 7: Operasyonel E-IKKY Regresyon ve Aracılık Etki Değerleri

Buna göre E-IKKY Kullanım Kolaylı̆̆g, İlişkisel İKY Uygulamaları ile E-i̇KY Kullanım Kolaylığı arasındaki ilişkiye kısmi aracılık etmektedir.

Operasyonel E-IKY Uygulamalarının E-İKY Algılanan Net Faydayı ne ölçüde yordadığının ve E-IKY Kullanım Kolaylığının aracı rol oynayıp oynamadığının araştırılması amacıyla yapılan analiz sonuçları Tablo 7'de verilmiştir.

Operasyonel E-İKY Uygulamalarının E-İKY Kullanım Kolaylığı ile (a yolu; $ß=0.603$ $\mathrm{SE}=.069, \mathrm{t}=8.749, \mathrm{p} ß .001,95 \% \mathrm{CI}[0.467$, 0.739]) pozitif ve anlamlı bir ilişki içinde olduğu bulunmuştur. Bu ilişkinin devamında E-IKKY Kullanım Kolaylığı ile E-İKY Algılanan Net Fayda arasındaki ilişki de anlamlı ve pozitif olarak bulunmuştur ( $b$ yolu, $\beta=0.682$, $\mathrm{SE}=.071, \mathrm{t}=9.560, \mathrm{p} ß .001,95 \% \mathrm{CI}[0.541$, 0.823]). Operasyonel E-İKY Uygulamaları ile E-İKY Algılanan Net Fayda arasındaki doğrudan etki ( $c$ ' yolu; $ß=0.197, S E=.081, t=2.433$, p $3.05,95 \%$ CI $[0.037,0.356])$ anlamlı bulunmuştur. Operasyonel E-İKY Uygulamaları ile E-IKKY Algılanan Net Fayda arasındak ilişkide E-İKY Kullanım Kolaylığı aracılığıy la dolaylı etkisi (ab yolu; $ß=0.411, \mathrm{SE}=.092$, $\mathrm{t}=6.344, \mathrm{p} ß .001,95 \% \mathrm{CI}[0.234,0.595])$ istatistiksel açıdan anlamlı bulunmuştur. Toplam etkinin ise pozitif ve anlamlı olduğ görülmektedir (c yolu; $ß=0.608, \mathrm{SE}=.083$, $\mathrm{t}=7.333, \mathrm{p} ß .001,95 \% \mathrm{CI}[0.444,0.771])$.

Sonuç olarak, önerilen model istatis-

Sonuç olarak, önerilen model istatistiki olarak anlamlı çıkmıştır $[\mathrm{F}(1,195)=$ $117.532, \mathrm{p}<.001, \mathrm{R} 2=.54$ ] ve toplam varyansın \%5'ini açılkladığı tespit edilmiştir. tiki olarak anlamlı çıkmıștır $[F(1,195)=$ 85.106, $\mathrm{p}<.001, \mathrm{R} 2=.46$ ] ve toplam var yansın \%4'ünü açıkladığı tespit edilmiştir. Buna göre E-İKY Kullanım Kolaylığı,
Operasyonel İKY Uygulamaları ile E-İKY Kullanım Kolaylığı arasındaki ilişkiye kısmi aracılık etmektedir.

\section{Sonuc}

Elektronik insan kaynakları, son yıllarda teknoloji devinim hızının artışı ve küreselleşmeyle birlikte tüm dünyadaki işletmeler ve çalışanlar üzerinde etkilerini artırmaktadır. Örgütler ise yeni pazarlara daha hızlı ulaşabilme, teknoloji ve bilginin getirdiği değişim dinamiklerini yakalama çabası içine girmiştir. Söz konusu değişimler, işletmelerin süreçlerini sürekli gözden geçirmelerini ve yeniliklere uyum sağlamalarını gerektirmektedir. Bu düzene ayak uyduramayan işletmeler, günümüz ekonomik düzeninden elenmeye mahkûmdur. Bu yüzden günümüzde birçok işletmenin elektronik insan kaynakları yönetimi üzerine çalışma yaptığı görülmektedir. Bu uygulamalar işletmeler için yeni kolaylıklar sağlarken, işletmelerin bilgi ve teknolojik donanımı bakımından yeterli düzeyde olup olmadığı hakkında da bilgi vermektedir. $\mathrm{Bu}$ işlem aynı zamanda işletmenin bel kemiğini oluşturan insan kaynağının ön planda tutulmasına olanak sağlamaktadır.

Son bölümde öncelikle araştırmanın konusu, amacı, önemi, varsayımları, kısıtları, metodolojisi incelenmiştir. Daha sonra çalışmanın temel amacını ortaya koyabilmek için, gerçekleştirilen anket çalışması ve bulgularına yer verilmiştir. Çalışmanın asıl amacı elektronik insan kaynakları yönetimi ve alg1lanan net faydanın, bankalar üzerinde kullanımının ve öneminin belirlenmesidir. Tarım, gıda, otomotiv, gayrimenkul, sağlık, lojistik, madencilik, turizm, ulaşım ve finans Türkiye'deki en önemli sektörlerdir. Bu sektörler 
arasında finans ve bankacıllk seçilmesinin en büyük nedeni elektronik insan kaynakları yönetimini en çok kullanan, yatırım yapan ve insan kaynakları faaliyetlerinin gelişmi olduğunun düşünüldüğü için finans ve bankacılık sektörü seçilmiştir.

Araştırmaya katılım sadece bankacılık ve finans sektöründen gerçekleştirildiği belirlenmiştir. Bölgelere göre ayrım yapıldığ zaman ise katılımın sadece Marmara Bölgesindeki İstanbul ilinden olduğu gözlenmiştir. $\mathrm{Bu}$ durumun Türkiye'nin genel durumunu temsil ettiği düşünülmektedir. Çünkü Türkiye'nin bankacılık bakımından en gelişmiş ili İstanbul'dur.

Yapılan analizler ile E-İKY Uygulamalarından Operasyonel E-İKY, İlişkisel E-İKY, Dönüşümsel E-IKKY alt boyutları ile E- İKY Algılanan Fayda, E- İKY Kullanım Kolaylığı anlamlı pozitif yönde korelasyonlar göstermektedir. Yapılan analizler sonucunda ortaya çıkan sonuçlar ile E-İKY Uygulamalar ölçeği Operasyonel E-IKKY, İlişkisel E-İKY, Dönüşümsel E-İKY alt boyutları ile E- İKY Algılanan Fayda ilişkisinde E- İKY Kullanım Kolaylığının kısmi aracı rolü bulunduğu sonuçları bulunmuştur.

E-İKY'nin insan kaynakları yönetiminin stratejik rolünü geliştirdiği, insan kaynaklarının idari işlerini kısalttığı ve İKY hizmetleriyle ilgili çalışanların tatminini arttırdığı ortaya çıkmıştır. E-İKY uygulamalarının maliyetlerin azalmasında ve verimliliğin artışında önemli rol oynayabileceği; E-IKKY uygulamaları sayesinde işletmelerin İK işlemleri için yaptıkları harcamalarda \%60'a varan tasarruf sağlayabildikleri görülmüştür.
Bankaların insan kaynakları çalışanlarından elde edilen bilgiler doğrultusunda E-İKY kullanımının; hız, zaman, maliyet tasarrufu, kurumsallık, kalite, yüksek yetkinlik, stratejilere etki ve verimlilik açısından önemli bir rekabet avantajı ve kolaylık sağladığı söylenebilir. Örgütler gelişen bu teknolojiler sonucunda istedikleri bilgilere istedikleri yerden ve istedikleri zamanda ulaşabilmekte ve istedikleri değişiklikleri yapabilmektedir. Ayrıca iletişim çevrimiçi ortama aktarılması sayesinde hem çalışanlar arasında hem de kurum ile çalışanlar arasında iletişim artmaktadır. Bununla birlikte İnsan Kaynakları uzmanları stratejik konulara yönelmede zaman kazanmaktadır.

\section{Kaynakça}

Allahverdi, M. (2006). Elektronik İnsan Kaynakları Yönetimi Ve Türkiye'deki Uygulamalarına Yönelik Bir Araştırma (Doctoral Dissertation, Selçuk Üniversitesi Sosyal Bilimler Enstitüsü).

Baron, R. M., \&Kenny, D. A. (1986). The Moderator-Mediator Variable Distinction in Social Psychological Research: Conceptual, Strategic, and Statistical Considerations. Journa of Personality and Social Psychology,51(6), s. 1173.

Berber, N., Đorđević, B., \&Milanović, S. (2018). Electronic Human Resource Management (E-Hrm): A New Concept For Digital Age. Strategic Management, 23(2), 22-32

Bryant, F. B., \&Yarnold, P. R. (1995). Principal Components Analysis and Exploratory and Confirmatory Factor Analysis. In L. G. Grimm \& P. R. Yarnold (Eds.), Reading and Understanding Multivariate Analysis. Washington, DC American Psychological Association.

Büyüköztürk, Ö., Şekercioğlu, G., \& Çokluk, Ş. (2010). Sosyal Bilimler İçin Çok Değişkenli İstatistik: SPSS ve LISREL Uygulamalar (Vol. 2). Ankara: Pegem Akademi.

Davis, F. D. (1989). Perceived Usefulness, Perceived Ease of Use, and User Acceptance Of Information Technology. MisQuarterly, s. 319 340 .

Doğan, A. (2011). Elektronik İnsan Kaynakları Yönetimi Ve Fonksiyonları.

Field, J. (2005). Social Capital and Lifelong Learning. Policy Press.
Gorsuch, R. L. (1983). Factor Analysis. Hillsdale, NJ: Lawrence Erlbaum Associates.

Gürbüz S. ve Şahin F. (2016). Sosyal Bilimlerde Araştırma Yöntemleri Felsefe Yöntem-Analiz. Ankara: Seçkin Yayınevi.

Hair, J. F., Celsi, M., Ortinau, D. J., \& Bush, R. P. (2010). Essentials of Marketing Research (Vol. 2). New York, NY: McGraw-Hill/Irwin

Iqbal, N., Ahmad, M., Allen, M. M., \&Raziq, M. M. (2018). Does EHrmImproveLabour Productivity? A Study Of Commercial Bank Workplaces İn Pakistan. Employee Relations.

Iwu, C. G. (2016). Effects Of TheUse Of Electronic Human Resource Management (E-Hrm) Within Human Resource Management (Hrm) Functions At Universities. Acta Universitatis Danubius. Administratio, 8(1).

Jolliffe, I. T. (2002). Graphical Representation of Data Using Principal Components. Principal Component Analysis, s. 78-110.

Karasar, N. (2011). Bilimsel Araştırma Yöntemi. Ankara: Nobel Yayınları.

Kenny DA, Kashy DA, Bolger N ve ark. (1998) Data analysis in socialpsychology. Thehandbook of socialpsychology, D.T. Gibert, S.T. Fiske, G.Lindzey (Ed), Berlin. Springer-Verlag, s.203-227.

Preacher, K. J., \& Hayes, A. F. (2008). Asymptotic and Resampling Strategies For Assessing and Comparing Indirect Effects in Multiple Mediator Models. Behavior Research Methods, 40(3), s. 879-891.

Saraç, E. Ö. (2016). İnsan Kaynakları Yönetimi Uygulamalarının Örgüt Performansı 
Üzerindeki Etkisinde İnsan Kaynakları Bilgi Sistemleri Kullanımının Rolü Üzerine Araştırma (Master's Thesis, Başkent Üniversitesi Sosyal Bilimler Enstitüsü)

Strohmeier, S. (2007). Research İn E-Hrm: Review And İmplications. Human Resource Management Review, 17(1), 19-37.

Ramezen, M., Nazari, Y., \&Ahmadi, M. M. (2013). The Effect Of Electronic Human Resources Management On Quality Of Services ProvidedBy Human Resources İn The İnsurance İndustry (Case Study: Iran InsuranceCompany İn Khorramabad City). Journal Of SocialIssues \& Humanities, 1(7), 223-232.

Rourke, N., \&Hatcher, L. (2013). A Step-byStep Approach to Using SAS for Factor Analysis and Structural Equation Modeling. SasInstitute.

Tansley, C., Newell, S., \& Williams, H. (2001). Effecting HRM-stylepracticesthrough an integratedhumanresourceinformationsystem: An e-greenfield site?. PersonnelReview.

Vatansever, Y. D. D. Ç., \& Yılmaz, N. (2015). İnsan Kaynakları Yönetimi'nin Görünen Yüzü: Fortune 500 İşletmeleri Web İçerik Analizi. Isguc The Journal Of Industrial Relations And Human Resources, 17(2), 210-236.

Winarto, W. (2018). Electronic Human Resources Management (E-Hrm) Adoption Studies: Past And Future Research. Derema (Development Research Of Management): Jurnal Manajemen, 13(1), 100-120. 
